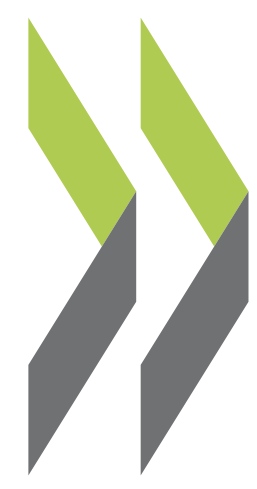

OECD Economics Department Working Papers No. 1564

$$
\begin{array}{r}
\text { The } 2018 \text { Indicators } \\
\text { on the Governance } \\
\text { of Sector Regulators - Part } \\
\text { of the Product Market } \\
\text { Regulation (PMR) Survey }
\end{array}
$$

\section{Lorenzo Casullo, Alexis Durand,} Filippo Cavassini 
ECONOMICS DEPARTMENT

THE 2018 INDICATORS ON THE GOVERNANCE OF SECTOR

REGULATORS

PART OF THE PRODUCT MARKET REGULATION (PMR) SURVEY

\section{ECONOMICS DEPARTMENT WORKING PAPERS No. 1564}

\section{Lorenzo Casullo, Alexis Durand and Filippo Cavassini}

OECD Working Papers should not be reported as representing the official views of the OECD or of its member countries. The opinions expressed and arguments employed are those of the author(s).

Authorised for publication by Alain de Serres, Deputy Director, Policy Studies Branch, Economics Department.

All Economics Department Working Papers are available at www.oecd.org/eco/workingpapers.

JT03450143 
OECD Working Papers should not be reported as representing the official views of the OECD or of its member countries. The opinions expressed and arguments employed are those of the author(s).

Working Papers describe preliminary results or research in progress by the author(s) and are published to stimulate discussion on a broad range of issues on which the OECD works.

Comments on Working Papers are welcomed, and may be sent to OECD Economics Department, 2 rue André Pascal, 75775 Paris Cedex 16, France, or by e-mail to eco.contact@oecd.org.

All Economics Department Working Papers are available at www.oecd.org/eco/workingpapers.

This document and any map included herein are without prejudice to the status of or sovereignty over any territory, to the delimitation of international frontiers and boundaries and to the name of any territory, city or area.

The statistical data for Israel are supplied by and under the responsibility of the relevant Israeli authorities. The use of such data by the OECD is without prejudice to the status of the Golan Heights, East Jerusalem and Israeli settlements in the West Bank under the terms of international law.

\section{(C) OECD (2019)}

You can copy, download or print OECD content for your own use, and you can include excerpts from OECD publications, databases and multimedia products in your own documents, presentations, blogs, websites and teaching materials, provided that suitable acknowledgment of OECD as source and copyright owner is given. All requests for commercial use and translation rights should be submitted to rights@oecd.org 


\title{
ABSTRACT/RÉSUMÉ \\ The 2018 Indicators on the Governance of Sector Regulators \\ - Part of the Product Market Regulation (PMR) Survey
}

Complementing the Product Market Regulation (PMR) survey, the Indicators on the Governance of Sector Regulators map the regulatory arrangements of 130 regulators across 38 countries and five network sectors: energy, e-communications, rail and air transport, and water. The indicators are structured along three components: independence, accountability and scope of action.

For the 2018 update, the OECD Secretariat and delegates of the Network of Economic Regulators (NER) revised the structure and content of the survey based on new best practice principles, guidance documents and the growing body of work of the NER on the performance of regulators.

The analysis shows that, while the governance arrangements of regulators vary considerably across countries and sectors, some key trends and correlations can be observed. These insights can support countries and regulators wishing to benchmark their governance practices and reform their governance arrangements.

Keywords: governance, economic regulators, independence, accountability

JEL codes: D73; K23; L38; L50; L97; L98

\author{
$* * * * * * * * *$ \\ Les indicateurs 2018 sur la gouvernance des régulateurs sectoriels \\ - Composante de l'enquête sur la réglementation des marchés de produits (PMR)
}

En complément de l'enquête sur la réglementation des marchés de produits (PMR), les Indicateurs sur la Gouvernance des Régulateurs Sectoriels cartographient les dispositifs réglementaires de 130 régulateurs opérants dans 38 pays et cinq secteurs : eau, énergie, télécommunications et transport ferroviaire et aérien. Les indicateurs sont structurés autour de trois composantes : indépendance, responsabilité et champ d'action.

Pour la mise à jour 2018, le Secrétariat de l'OCDE et les représentants du Réseau des régulateurs économiques (NER) ont modifié la structure et le contenu de l'enquête sur la base des nouveaux principes de bonnes pratiques, des documents d'orientation et des nombreux travaux du NER sur la performance des autorités de régulation.

L'analyse montre que, si les dispositifs de gouvernance des régulateurs varient considérablement d'un pays et d'un secteur à l'autre, certaines tendances et corrélations clés peuvent être observées. Ces informations peuvent être utiles aux pays et régulateurs qui souhaitent comparer leurs pratiques et réformer leurs dispositifs de gouvernance.

Mots-clés : gouvernance, régulateurs économiques, indépendance, responsabilité.

Classification JEL: D73; K23; L38; L50; L97; L98 


\section{Table of Contents}

The 2018 Indicators on the Governance of Sector Regulators ........................................................ 6

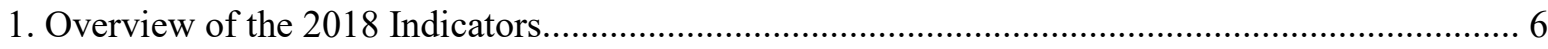

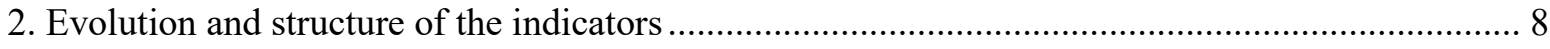

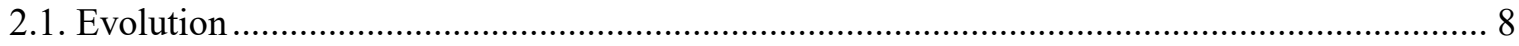

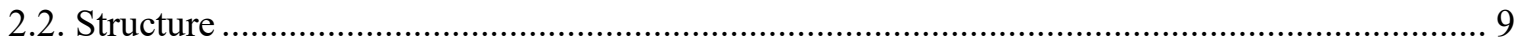

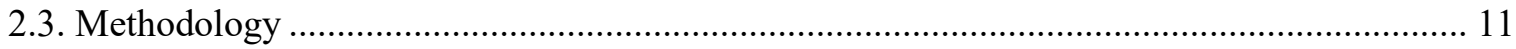

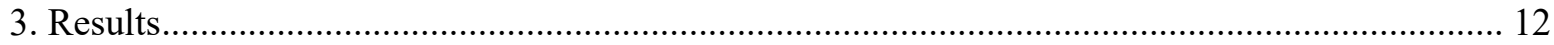

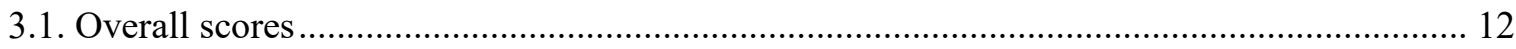

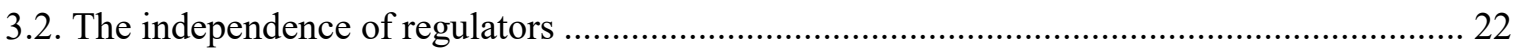

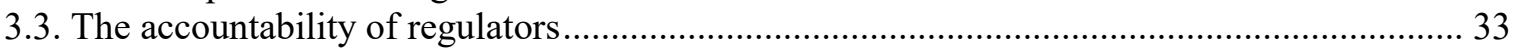

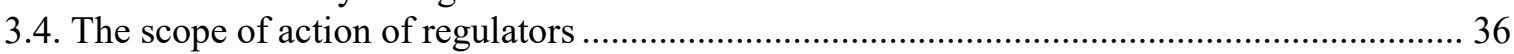

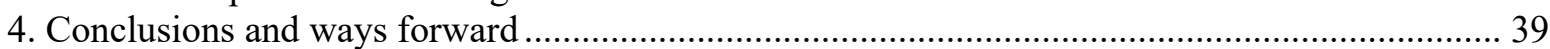

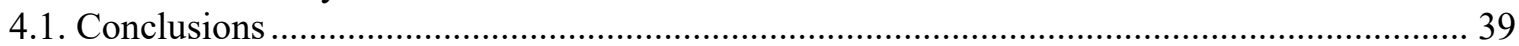

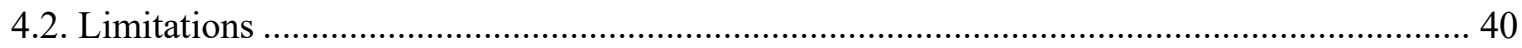

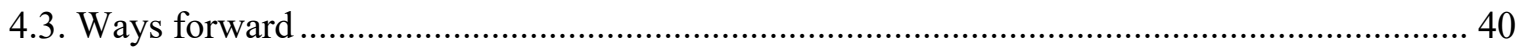

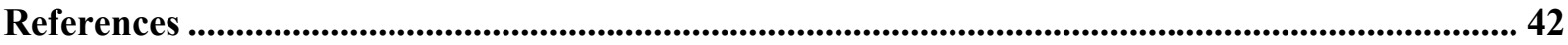

Annex A. Countries and regulators included in the 2018 Indicators on the Governance of

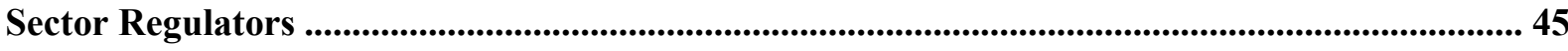

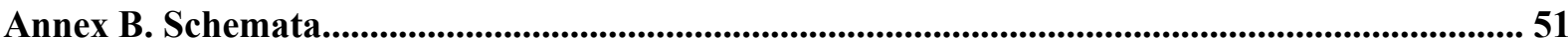

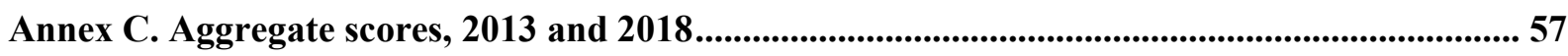

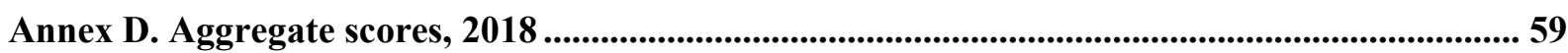

Annex E. Regulatory activities, by sector.................................................................................................. 62

Annex F. Why and how the 2018 and 2013 questionnaires differ................................................. 63

\section{Tables}

Table 1. Number of surveys analysed by sector and category, 2018 and 2013 ................................. 11

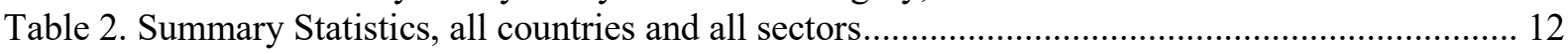

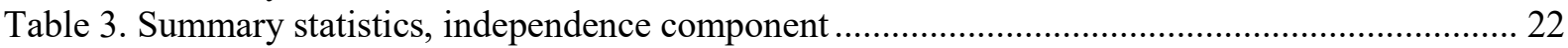

Table 4. Number of regulators issuing opinions on draft legislation or policy documents .................. 28

Table 5. Energy sector mean independence scores for countries where national, state, regional provincial or municipal governments hold $\geq 50 \%$ equity stakes in the largest firm ..................... 32

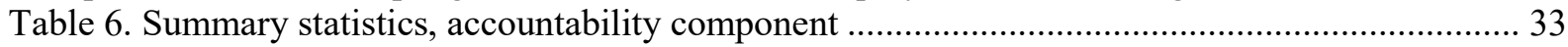

Table 7. Summary statistics, scope of action component .................................................................... 36

Table 8. Average scores, scope of action component, independent and ministerial regulators ............ 38

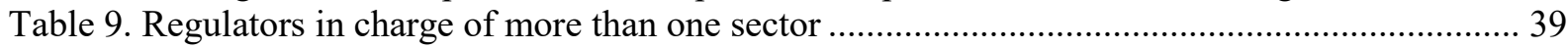

\section{Figures}

Figure 1. Structure of the questionnaire for the Indicators on the Governance of Sector Regulators ... 10

Figure 2. The governance of regulators in the energy sector ............................................................. 13

Figure 3. The governance of regulators in the e-communications sector ................................................ 15 


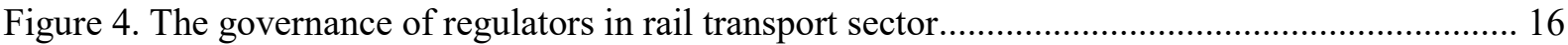

Figure 5. The governance of regulators in the air transport sector ..................................................... 17

Figure 6. The governance of regulators in the water sector ............................................................. 19

Figure 7. Relationship between independence and accountability scores ............................................ 20

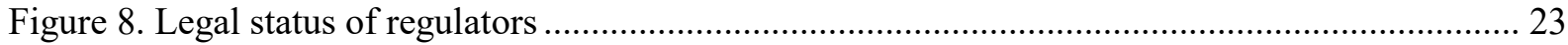

Figure 9. The status of regulators in each sector, EU and non-EU countries ..................................... 24

Figure 10. The status of regulators in each sector, OECD and non-OECD countries......................... 25

Figure 11. Regulators receiving guidance from the government ...................................................... 27

Figure 12. Bodies other than a court that can overturn regulators' decisions ...................................... 28

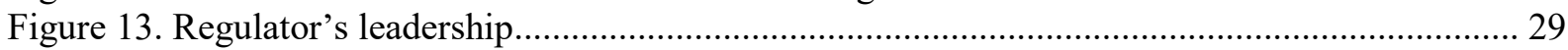

Figure 14. Among independent regulators, can the agency head/board members accept jobs in the government and/or the regulated sector after their term of office? .......................................... 30

Figure 15. How can the agency head/board members be dismissed from office?................................. 31

Figure 16. Regulators funded through budget appropriations, fees or both ....................................... 32

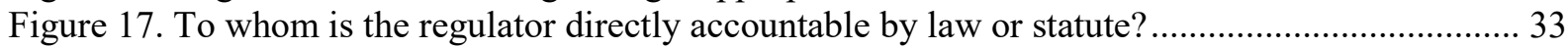

Figure 18. Does the regulator publish draft decisions and collect feedback from stakeholders?.......... 34

Figure 19. What types of performance information does the regulator collect? ................................. 35

Figure 20. Among regulators who collect performance information, is the information published on

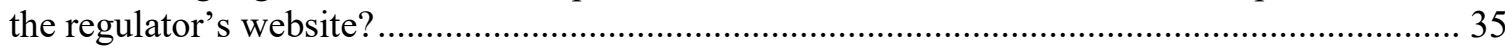

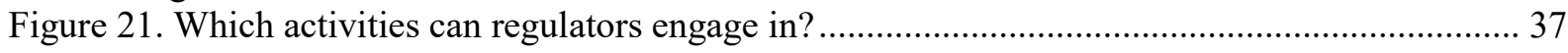




\title{
The 2018 Indicators on the Governance of Sector Regulators
}

\author{
By Lorenzo Casullo, Alexis Durand and Filippo Cavassini ${ }^{1}$
}

\section{Overview of the 2018 Indicators}

1. Little is known about comparative governance arrangements of economic regulators for network sectors, despite the key role that these institutions play as impartial and evidence-based referees in market economies. While sectoral policies and primary regulations are typically developed by the executive branches of government, economic regulators are frontline agencies of the public sector tasked with promoting competition, setting prices, enforcing regulations and standards, protecting consumers and many other functions.

2. Independence is an important feature of the governance arrangements of sector regulators, enabling them to manage the complexity of competitive markets and ensure the consistency of public policies over time. The 2012 recommendation of the OECD Council on Regulatory Policy and Governance recognised the importance of independent regulatory agencies, noting that independent agencies improve trust that decisions are fair and impartial. It recommends that the establishment of independent regulatory agencies be considered where independence would bolster public confidence, where the government and private entities fall under the same regulatory framework, and where regulator decisions can have significant economic impacts on regulated entities (OECD Council on Regulatory Policy and Governance, 2012[1]) When regulators enjoy a degree of independence from both government and industry, this can "provide greater confidence and trust that regulatory decisions are made with integrity" (OECD, 2014 $\left.{ }_{[2]}\right)$. Independent regulators can better provide a "credible commitment" to adhere to long-term political goals when the political power delegates activities to them, signalling to the public, investors and market actors that these goals will not be abandoned in the name of shortterm gain, electoral popularity or sectorial interest (Tucker, 2018, pp. 13-14 $4_{[3]}$ ).

3. A comparative assessment of independence arrangements goes hand in hand with comparisons of the scope of action that different regulators enjoy. Key differences are likely to emerge across countries and sectors, but there is a common rationale for delegating

\footnotetext{
${ }^{1}$ Contact details for the authors are as follows: lorenzo.casullo@oecd.org, alexis.durand@oecd.org and filippo.cavassini@oecd.org. The authors would like to thank Rhys Morgan for his contribution to data collection and verification, OECD staff and especially Cristiana Vitale, Isabelle Wanner and Douglas Sutherland (Economics Department), Nick Malyshev, Céline Kauffman and Anna Pietikainen (Regulatory Policy Division) for their inputs to the analysis, Luca Bellodi (University College London) and Christel Koop (King's College London) for their feedback on earlier drafts of the paper.
}

Members of the Network of Economic Regulators (NER) at the OECD provided invaluable support at the data collection stage and substantial inputs and comments to earlier drafts of the paper, including at a plenary session in April 2019 in Paris. Special thanks go to Alan Sutherland (WICS, Scotland), Anne Yvrande-Billon and Eugenie Berthelot (ARAFER, France), Annegret Groebel (BNetzA, Germany), Inga Žilienè and Irma Vasarytè (NCC, Lithuania), Luisa Perrotti (ART, Italy), and Melissa Mathieson and Andrea Boras (NEB, Canada). 
powers to independent regulators - namely that sector regulators can be centres of expertise, better placed at overcoming information asymmetries and enhancing the efficiency of rule-making (Huber and Shipan, 2002 ${ }_{[4]}$ ).

4. As regulatory agencies have the power to affect prices, investment, property rights and other fundamental economic outcomes (OECD, 2016 $\left.6_{[5]}\right)$, and enjoy various degrees of independence, formal accountability becomes crucial to enhance legitimacy and increase public trust in regulatory agencies. In turn, "legitimacy grounds and comprises the capacity of an agency to pursue its mandate as part of the broader state apparatus, without relying wholly on coercive power" (Tucker, 2018 $8_{[3]}$ ).

5. The 2018 edition of the Indicators on the Governance of Sector Regulators aims to shed light on the governance arrangements of economic regulators. It offers a comprehensive overview of 130 unique regulatory agencies in 38 countries, relying on information compiled by regulators and governments and independently reviewed by the OECD Secretariat. Indicators for additional countries will be added once they are completed over the course of $2019 .{ }^{1}$

6. The 2018 indicators highlight trends around the independence, accountability and scope of action of sector regulators by providing a uniform quantitative scoring system that enables comparisons across sectors and countries. The analysis of those trends can provide insights for regulatory agencies wishing to compare their arrangements to others, for central government units in charge of regulatory policy, as well as for researchers and practitioners aiming to study the impact of sector governance on the performance of regulated sectors. The key findings are:

- Governance structures vary considerably across countries and sectors. Regulators in the energy and e-communications sectors tend to be closer to good practice and air transport regulators tend to be further away. In general, accountability arrangements are closer to good practice than independence arrangements. However, all results are context dependent and they should be viewed in light of institutional, political and market differences across countries.

- Greater autonomy comes with stronger accountability structures. There is a positive and statistically significant correlation between independence and accountability scores in all sectors. These results are consistent with the findings of the analysis of the 2013 indicators.

- Governance arrangements around the independence of regulators show the smallest variation, suggesting some form of convergence. Recent EU Directives in energy and rail appear to have played a role in harmonising the independence arrangements of a large number of regulators in the survey.

- Practical arrangements beyond legal status determine whether a regulator is effectively independent. While most regulators identify as "independent bodies with adjudicatory, rule-making or enforcement powers" based on national laws and statutes, mapping the practical determinants of independence requires looking at their relationship with the executive, staffing, budget and spending autonomy.

- Higher independence may be correlated to structural characteristics of the regulated sector. For example, where government has a majority stake in electricity generation, import, transmission, distribution and retail supply, preliminary analysis suggests that energy regulators appear to have lower independence. 
- Most regulators are accountable to the executive. The exception is ecommunications regulators, half of which are accountable to parliament or congress. There has been little change in statutory requirements since 2013.

- The vast majority of regulators provide opportunities for stakeholders to comment on draft decisions. Stakeholder engagement increasingly takes place through online consultations and occurs even in the absence of a legislative requirement. However, over one-quarter of regulators in the rail and air sectors do not consult with stakeholders regularly.

- The regulators surveyed perform a wide range of functions; independent regulators more so than ministerial ones. While most are tasked with enforcing consumer and industry standards, few of them are involved in the formulation of those standards in the rail, air and water sector. Energy and e-communications regulators typically regulate prices.

- Nearly $90 \%$ of regulators contribute in some way to the policy process. Regulators can offer substantial expertise and advice that can improve the quality of new policies and laws. Their involvement usually takes place in formal channels such as parliamentary hearings and inputs to public consultations.

7. The remainder of this paper is structured as follows. Section 2 describes the methodology used to calculate the 2018 indicators, including data collection and scoring. Section 3 presents the overall results by sector, as well as more detailed analysis of independence, accountability and scope of action arrangements. Section 4 presents some conclusions, limitations and ways forward.

\section{Evolution and structure of the indicators}

\subsection{Evolution}

8. The OECD's Product Market Regulation (PMR) survey takes stock of the extent to which a country's laws and regulation foster competition every five years. The PMR includes Sector Indicators that measure the regulatory barriers to firm entry and to competition at the level of individual sectors, including e-communications, transport (by air, rail, road, and water) and energy. These PMR Sector Indicators are based on a dataset compiled by the OECD from the answers provided by national authorities to an extensive questionnaire. The information collected concerns the de jure policy set, including the presence of the state through ownership and control of operators in each of the sectors, the extent to which the market is open to competition, and whether access regulation is designed to foster competition.

9. In 2013, a new set of indicators measuring regulatory management practices by economic regulators was developed alongside the PMR Sector Indicators. Economic regulators are broadly defined as institutions or bodies that are authorised by law to exercise regulatory powers over a sector for the purpose of setting prices and/or improving the operation of the market so that consumers have access to safe and quality services, and network operators and service providers receive a reasonable rate of return on their investment. These 2013 indicators covered economic regulators in six network sectors electricity, gas, telecom, railroad transport infrastructure, airports and ports.

10. The 2018 Indicators on the Governance of Sector Regulators mark the second edition of these new indicators of governance arrangements in sector regulators. For the 2018 indicators, in line with changes to the network components of the PMR Sector 
Indicators, the sector coverage of the indicators changed to better reflect an evolving regulatory landscape and to focus on the following sectors: energy (previously electricity and gas) ${ }^{2}$, e-communications (previously telecommunications), rail transport, air transport (previously airports only) and water (new). The questions in the telecommunications questionnaire were updated to better capture the characteristics of regulation in a rapidlytransforming sector, and the questions in the air sector were broadened to capture regulation beyond airports. The water sector was added, reflecting a trend of increased corporatisation and regulatory oversight at the national level in this sector. The ports sector was removed from the 2018 questionnaire as regulatory functions in this sector, when at all established by legislation, often fall under the responsibility of sub-national authorities, and the questionnaire is designed to capture arrangements primarily in regulators operating on the national level.

\subsection{Structure}

11. The questionnaire compiled by regulators and government authorities for the 2018 Indicators on the Governance of Sector Regulators provides a snapshot of governance arrangements within three components: independence, accountability and scope of action (Koske et al., 2016[6] $)$. The components of the questionnaire are described in greater depth below.

- Independence: This component maps the degree to which a regulator operates independently and with no undue influence from both the political power and the regulated sectors. Questions are organised into three subsections: relationship with the executive, staff and budget. It seeks to measure aspects of de facto independence through a variety of dimensions beyond only de jure independence.

- Accountability: This component covers the accountability of the regulator vis-à-vis various stakeholders, including the government, parliament, the regulated industry and the general public. It captures the adherence to regulatory management tools and looks at the collection, use, publication and reporting of performance information.

- Scope of action: This component sheds light on the range of activities that the regulator performs, including tariff-setting, issuing standards, enforcement activities and sanctioning powers.

\footnotetext{
${ }^{2}$ The questionnaire merges the electricity and gas sectors because most countries do not have a separate gas regulator. The two countries with distinct gas sector regulators (Argentina and Brazil) completed two surveys, one for each regulator; the resulting scores were averaged into a single country score for the energy sector.
} 
Figure 1. Structure of the questionnaire for the Indicators on the Governance of Sector Regulators

\section{Indicators on the Governance of Sector Regulators}
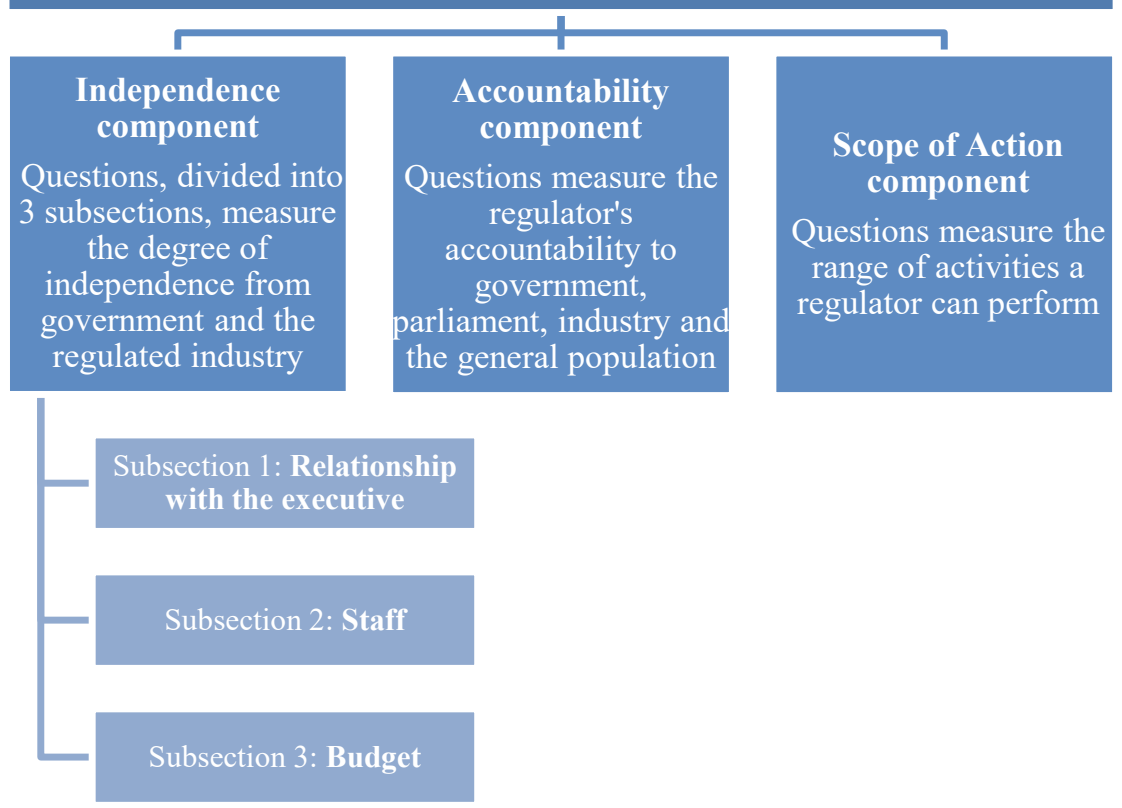

12. In 2018, the indicators were calculated for 38 countries (35 OECD member countries and 3 non-OECD member countries), a net increase of five countries from 2013. Table 1 shows the number of questionnaires completed for each sector in 2013 and 2018. These counts include 15 multi-sector regulators that completed surveys for more than one sector under their purview (see Table 9 for a full list of multi-sector regulators included). ${ }^{3,4}$ The dataset includes both ministerial regulators and independent regulators with adjudicatory, rulemaking or enforcement powers (with 37 ministerial regulators and 93 independent regulators). While the questionnaire primarily captures governance arrangements in regulators operating at the national level (including regulators in federal

\footnotetext{
${ }^{3}$ Multi-sector regulators are defined as regulators overseeing more than one sector (out of the five sectors covered in this survey).

${ }^{4}$ Several countries have unique arrangements for regulatory authorities that cannot be fully reflected in the results. Two examples, a country where regulators share competencies in the same sector and countries with 'regulatory committees', are described below.
}

The Czech Republic water regulator questionnaire covers the Co-ordinating Committee for the Regulation of Water and Sewerage Systems, which coordinates regulation made by other administrative bodies involved in the water sector. Part of the committee's mandate is to ensure socially acceptable water and sewer charges. The South African air regulator questionnaire covers the Regulating Committee, a committee within the department of transport that grants permission to levy certain tariffs across the airports owned by the regulated company.

While the questionnaire for the air regulator for Italy covers Autorità di Regolazione dei Trasporti (ART), regulatory duties in the air sector are shared between ART and the Civil Aviation Authority (Ente Nazionale per l'Aviazione Civile, ENAC). 
states), respondents have the option to answer on behalf of a subnational authority. Annex A contains a full list of participating countries and regulators.

Table 1. Number of surveys analysed by sector and category, 2018 and 2013

\begin{tabular}{lccccc}
\hline & Energy $^{5}$ & E-comms & Rail & Air & Water \\
\hline $\mathbf{2 0 1 8}$ & 40 & 37 & 33 & 31 & 20 \\
& & & & & \\
\hline $\mathbf{2 0 1 3}$ & Energy & Telecoms & Rail & Air & Ports \\
\hline
\end{tabular}

Note: Multi-sector regulators only counted once as independent/ministerial regulators.

Source: OECD 2013 and 2018 Databases on the Governance of Sector Regulators.

13. Adjustments in the 2018 questionnaires limit the comparability between the two editions. First, the content of the regulator questionnaires changed after 2013. These changes were especially numerous in the independence section, where questions were updated to better capture elements that contribute to an organisational culture of independence through not only formal but also practical arrangements (see Annex F for an overview of why and how the 2013 and 2018 questionnaires differ). As described above, sector coverage has also changed. Second, the review process for regulator data changed between the two surveys, with reviewers ensuring that every question was answered in the 2018 review.

\subsection{Methodology}

\subsubsection{Process}

14. Questionnaires for the PMR survey including the questionnaires for the Indicators on the Governance of Sector Regulators are shared with designated contact points. For this version of the questionnaire, the OECD Secretariat ensured that economic regulators were given the opportunity to answer the questionnaire for the Indicators on the Governance of Sector Regulators, providing the opportunity to submit joint responses to the OECD in coordination with their PMR ministry contact points.

15. The OECD Secretariat reviewed the responses received. Reviewers assessed the respondents' understanding of the questions, adherence to drop-down menu categories for closed-ended questions, accuracy of answers, and completeness of responses. When the team proposed changes or encountered questions, they checked both with NER delegates and with Ministry contact points. In the rare cases when the OECD reviewers were unable to make contact with a respondent, they carried out independent research on the outstanding questions by consulting other questionnaire responses, experts, national legislation, relevant publications and regulator websites.

\footnotetext{
${ }^{5}$ Responses were received for separate electricity and gas regulators in Argentina and Brazil, while the other countries only have a single regulator survey in the energy sector. New Zealand has two energy regulators: one for electricity (the Electricity Authority) and one for gas (Gas Industry Company Limited). Because the role and function of the Gas Industry Company Limited falls outside of the definition of an economic regulator, answers about the company were excluded from this exercise.
} 


\subsubsection{Scoring}

16. For each of the five sector regulators analysed, the questionnaire asks 77 closedended questions. With 130 regulators participating, the questionnaire captured around 10,000 total answers and on average 260 answers per country.

17. In line with the PMR methodology, answers are scored on a scale from zero (most effective governance arrangement) to six (least effective governance arrangement). Equal weights are assigned to all questions and sub-questions in order to avoid placing greater value on some of the governance components. Question scores are aggregated to provide an overall score between zero and six for each component, as detailed in the schemata in Annex B.

\section{Results}

Note to readers: The indicators vary from zero to six from the most to the least effective governance arrangements. The reported score is an average of equally-weighted questions across the three components.

Unless otherwise specified, figures and charts include OECD and non-OECD member countries.

\subsection{Overall scores}

18. The strength of governance arrangements varies considerably between countries (Table 2). On average, the accountability component of the survey is closest to good practice (with an overall average of 1.72). With a standard deviation (sd) of 0.54 , results in the independence component tended to remain closer to the mean when compared to the accountability section $(\mathrm{sd}=0.72)$ and the scope of action $(\mathrm{sd}=0.64)$. This result suggests that governance arrangements related to independence tend to vary less between countries than those related to the other two sections. Excluding the three non-OECD countries does not result in considerable changes in the summary statistics, with only a marginal decrease (around 0.01 ) in the average scores for each component. Full results by country and sector are shown in Annex D.

Table 2. Summary Statistics, all countries and all sectors

\begin{tabular}{llll}
\hline & Independence & Accountability & Scope of Action \\
\hline $\min$ & 0.95 & 0.35 & 0.77 \\
$\max$ & 3.11 & 2.89 & 3.27 \\
range & 2.16 & 2.54 & 2.50 \\
mean & 1.88 & 1.72 & 1.91 \\
std.deviation & 0.54 & 0.72 & 0.64 \\
\hline
\end{tabular}

Note: The indicators vary from zero to six from the most to the least effective governance arrangements. The reported score is a simple average of the scores across sectors.

Source: OECD 2018 Database on the Governance of Sector Regulators.

\subsubsection{Results by sector}

19. The results in Figure 2 focus on the scores of the energy sector. This sector has the highest number of dedicated regulatory authorities, with 36 regulators that identified as 
independent bodies with adjudicatory, rule-making or enforcement powers, and only four ministerial departments/agencies.

\section{Energy}

20. The energy sector has the lowest average independence score across all countries (with a mean of 1.68). The variation between regulator scores is lower than in other sectors with a standard deviation of 0.58 , suggesting that independence arrangements tend to be more closely aligned among energy regulators. The energy sector's mean accountability score (1.47) is lower than that of the rail (2.07), air (2.35) and water (1.81) sectors, but higher than that of the e-communications sector (1.22). In the energy sector, two regulators - Spain's National Authority for Markets and Competition and Greece's Regulatory Authority for Energy - have received scores of zero in the accountability component as they have reported the highest number of arrangements regarded as good practice. The average score for scope of action is higher in the energy sector (1.43) than in the ecommunications sector (1.05), but lower than the other sectors (with a mean of 2.20 in rail, 3.01 in air and 2.47 in water). Energy regulators across the sample enjoy very different powers and responsibilities, as scores in the scope of action section range from 0.23 in Greece and Lithuania to 4.15 in Chile.

Figure 2. The governance of regulators in the energy sector All countries and OECD average
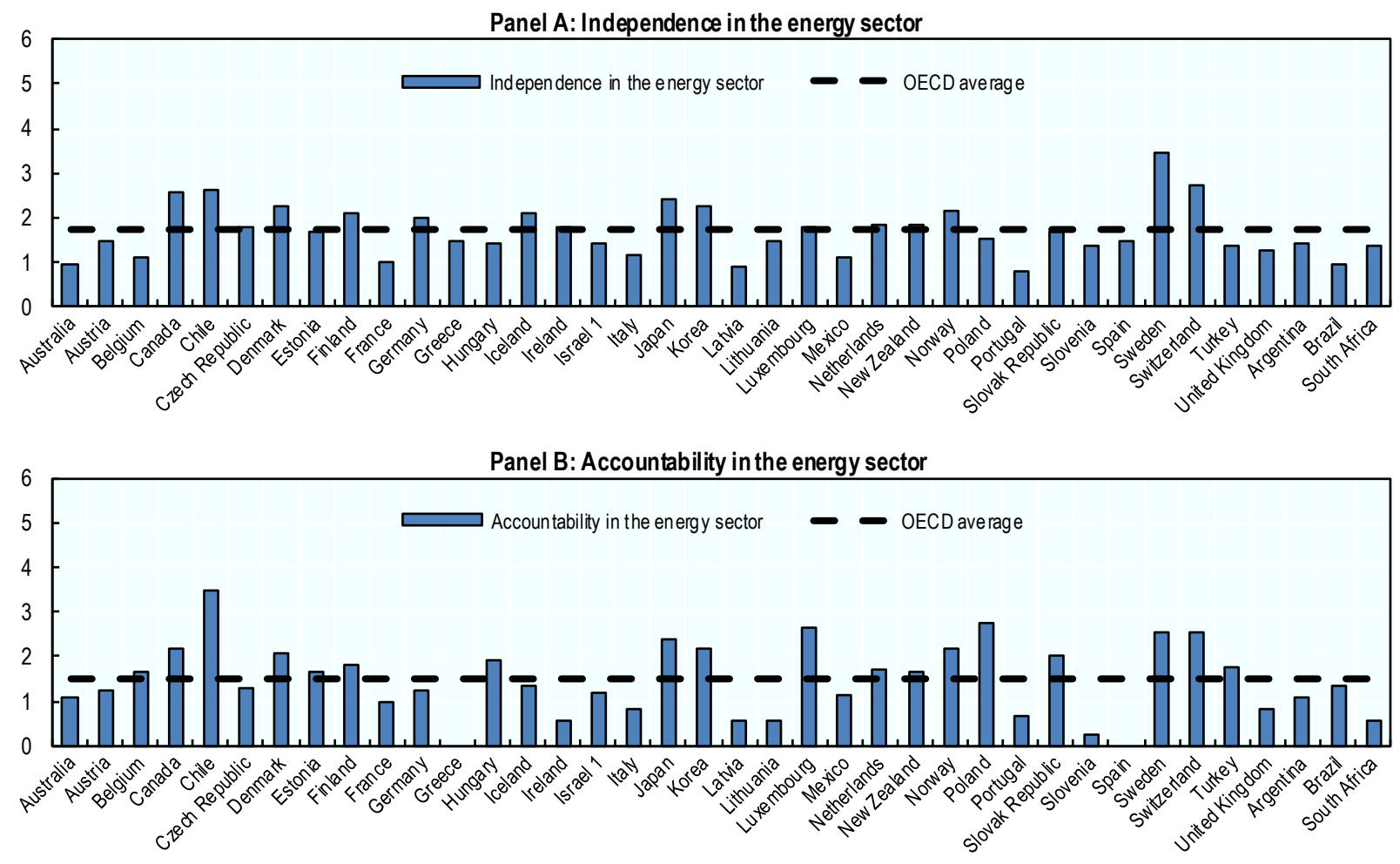


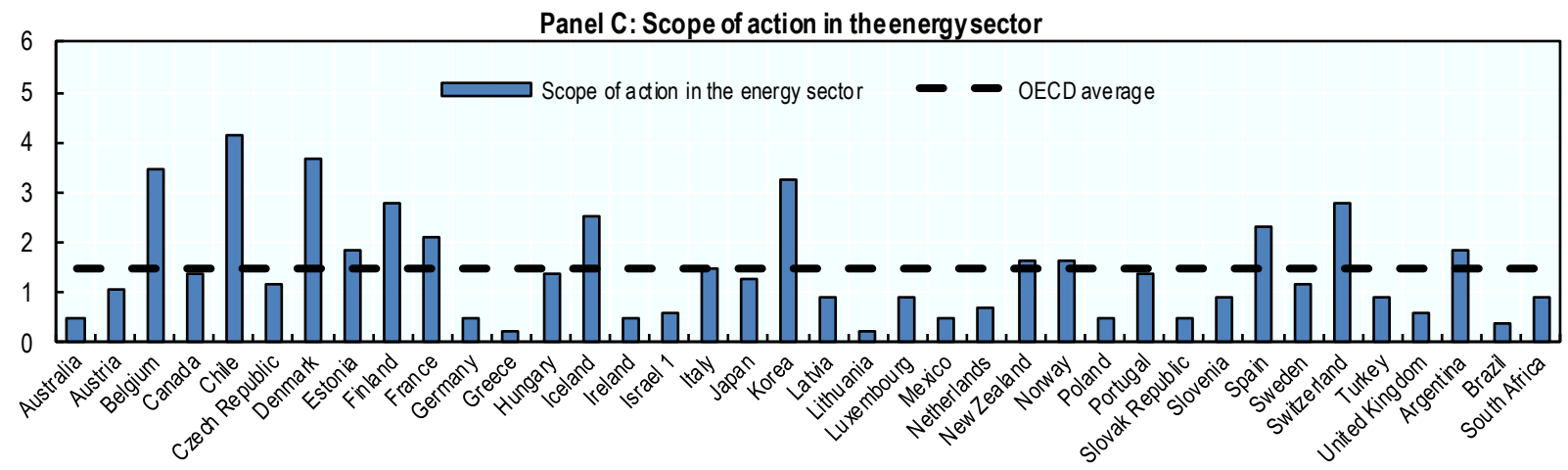

Notes: The indicators vary from zero to six from the most to the least effective governance structure.

1 The statistical data for Israel are supplied by and under the responsibility of the relevant Israeli authorities. The OECD average does not include data from the United States and non-OECD members (Brazil, Argentina and South Africa).

The use of such data by the OECD is without prejudice to the status of the Golan Heights, East Jerusalem and Israeli settlements in the West Bank under the terms of international law.

Source: OECD 2018 Database on the Governance of Sector Regulators.

\section{E-communications}

21. The results in Figure 3. focus on the scores of the e-communications sector. This is the sector where the highest number of countries attains a score between zero and one (with five regulators receiving a score of zero in the accountability component and two in scope of action). Alongside the lowest average accountability and scope of action scores, this suggests that the regulators in charge of this sector have adopted governance arrangements that more closely reflect good practice in these areas.

22. The e-communications sector has an average independence score across all countries of 1.71, just above that of the energy sector. The lowest average accountability score (1.22) indicates that e-communications regulators more closely adhere to accountability good practices. Scores are especially low for regulators in Belgium, Ireland, Italy, Mexico and Spain. In addition, e-communications regulators tend to have a broader scope of action than regulators in other sectors: Finland and Sweden's regulators appear to enjoy the broadest mandates, both with scores of zero in this component. 
Figure 3. The governance of regulators in the e-communications sector

All countries and OECD average

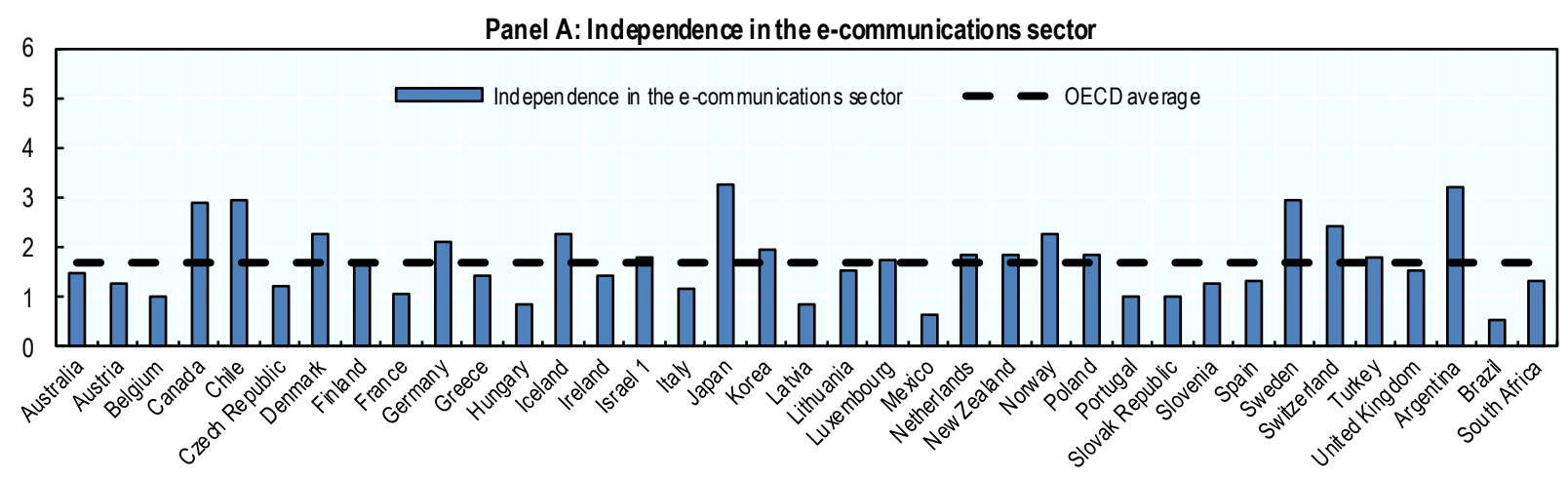

Panel B: Accountability in the e-communications sector
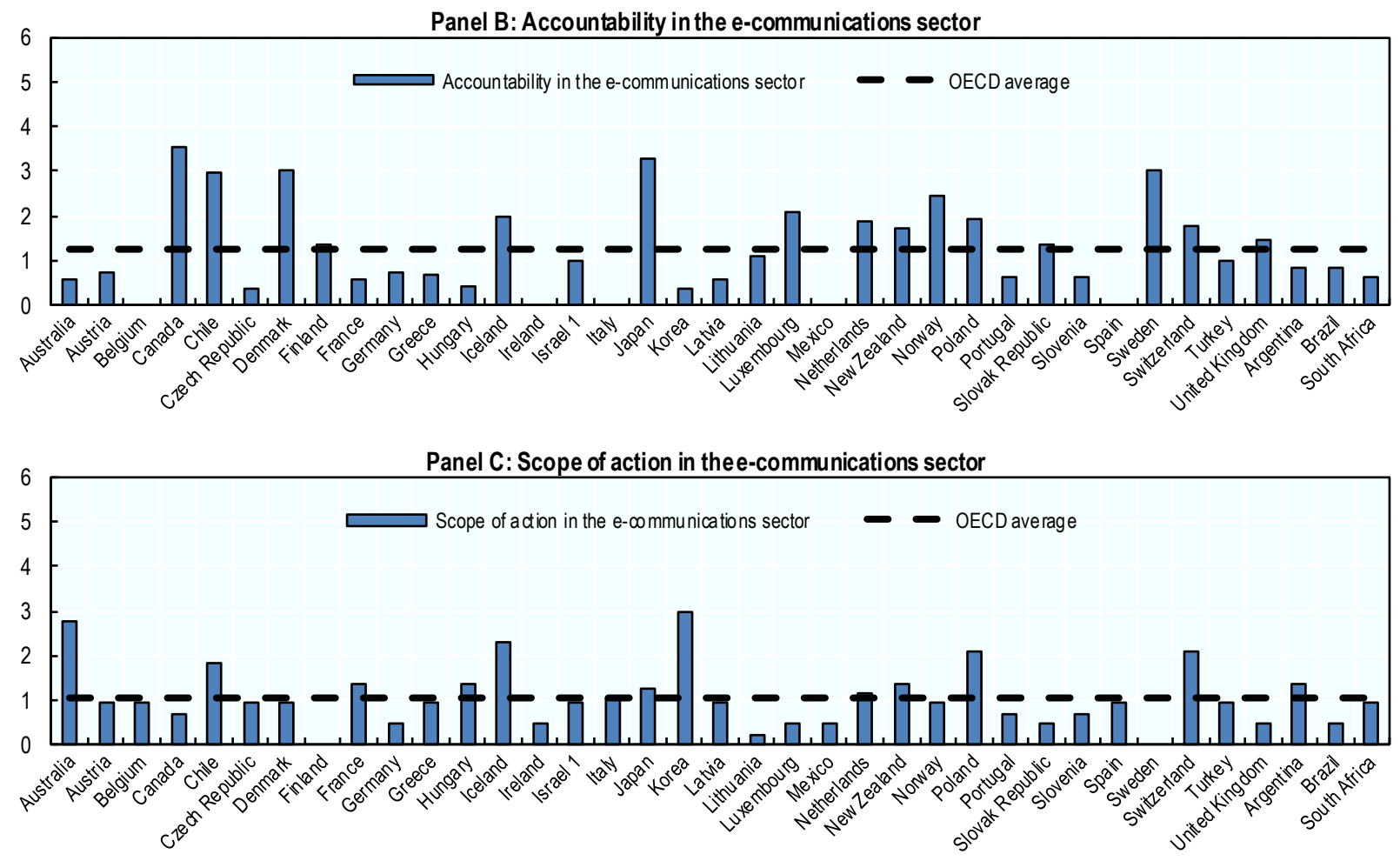

Notes: The indicators vary from zero to six from the most to the least effective governance structure.

The OECD average does not include Estonia and non-OECD members (Brazil, Argentina and South Africa).

1 The statistical data for Israel are supplied by and under the responsibility of the relevant Israeli authorities. The use of such data by the OECD is without prejudice to the status of the Golan Heights, East Jerusalem and Israeli settlements in the West Bank under the terms of international law.

Source: OECD 2018 Database on the Governance of Sector Regulators.

\section{Rail transport}

23. The results in Figure 4 focus on the scores of the rail transport sector. Transport regulators have, on average, a smaller scope of action than in the energy and ecommunication sectors (with a score of 2.20 in the rail sector, compared to 1.43 in the 
energy sector and 1.05 in e-communications). The rail regulators with the broadest mandates are in France, Poland and the United Kingdom.

24. The average independence score of the rail sector (1.90) is the second highest among all sectors. The variation between governance arrangements in the accountability section is notable, with regulators in Australia, Germany, Italy, Spain and the United Kingdom being the closest to the most effective governance arrangements.

Figure 4. The governance of regulators in rail transport sector

All countries and OECD average
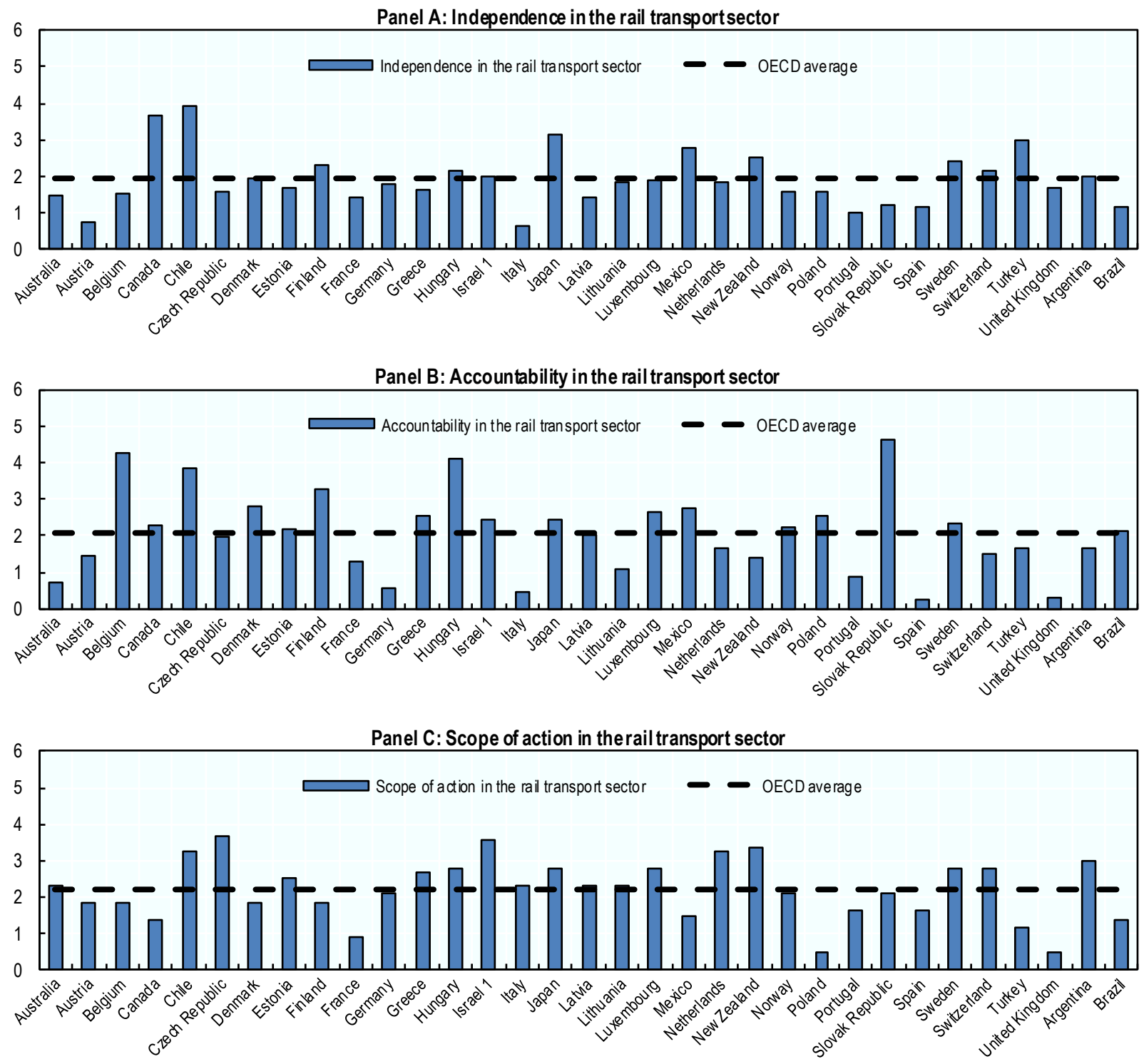

Notes: The indicators vary from zero to six from the most to the least effective governance structure.

The OECD average does not include Iceland, Ireland, Korea, Slovenia and the United States and excludes nonOECD members (Brazil, Argentina and South Africa).

1 The statistical data for Israel are supplied by and under the responsibility of the relevant Israeli authorities. The use of such data by the OECD is without prejudice to the status of the Golan Heights, East Jerusalem and Israeli settlements in the West Bank under the terms of international law.

Source: OECD 2018 Database on the Governance of Sector Regulators. 


\section{Air transport}

25. The results in Figure 5 focus on the scores of the air transport sector. A large number of regulatory functions in this sector are performed by Civil Aviation Authorities (CAAs), which are typically also in charge of safety and performance standards. Many CAAs are affiliated to a ministry. Independence scores are the lowest for those multi-sector regulators that oversee the air sector as well as the rail sector, with a mean independence score of 1.67 compared to a mean of 2.44 among air regulators without rail responsibilities. The spread of scores in the accountability section varies greatly: with a score of 4.91 , accountability arrangements for regulators in South Africa appear to be furthest from good practice.

Figure 5. The governance of regulators in the air transport sector

All countries and OECD average

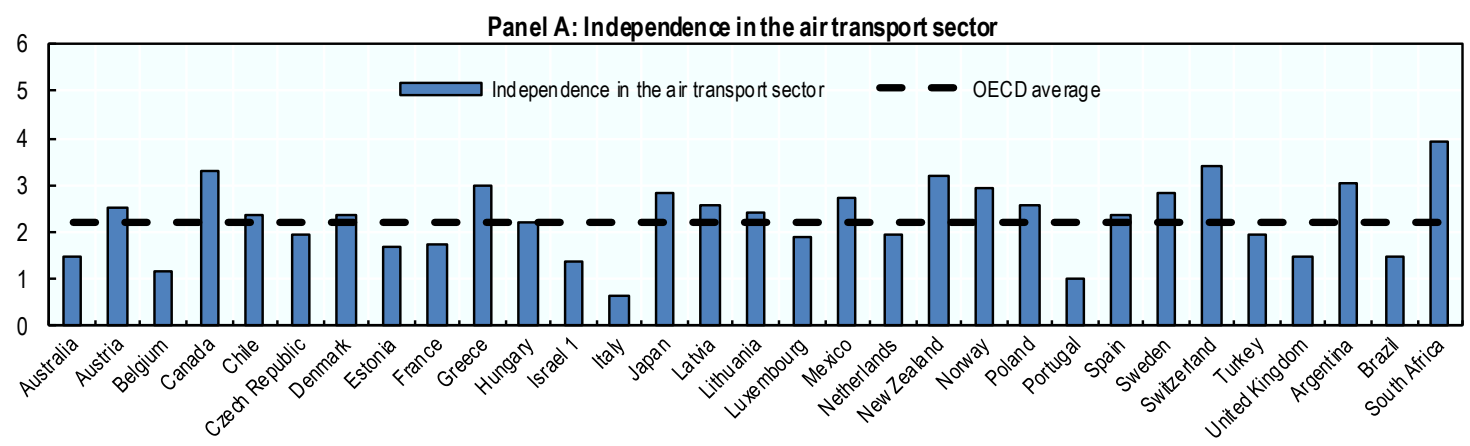

Panel B: Accountability in the air transportsector

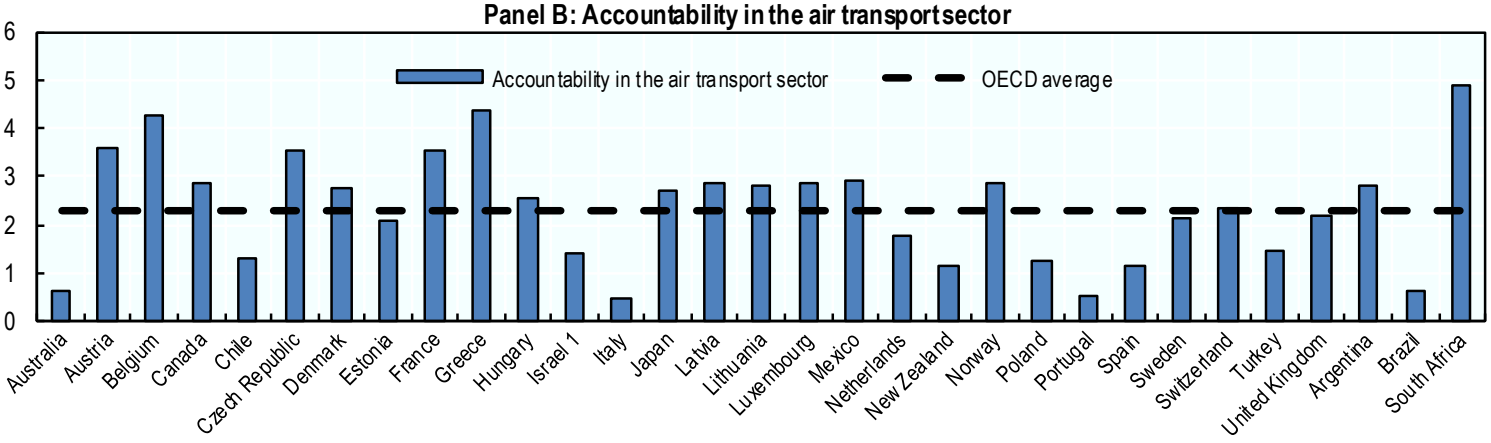

Panel C: Scope of action in the air transport sector

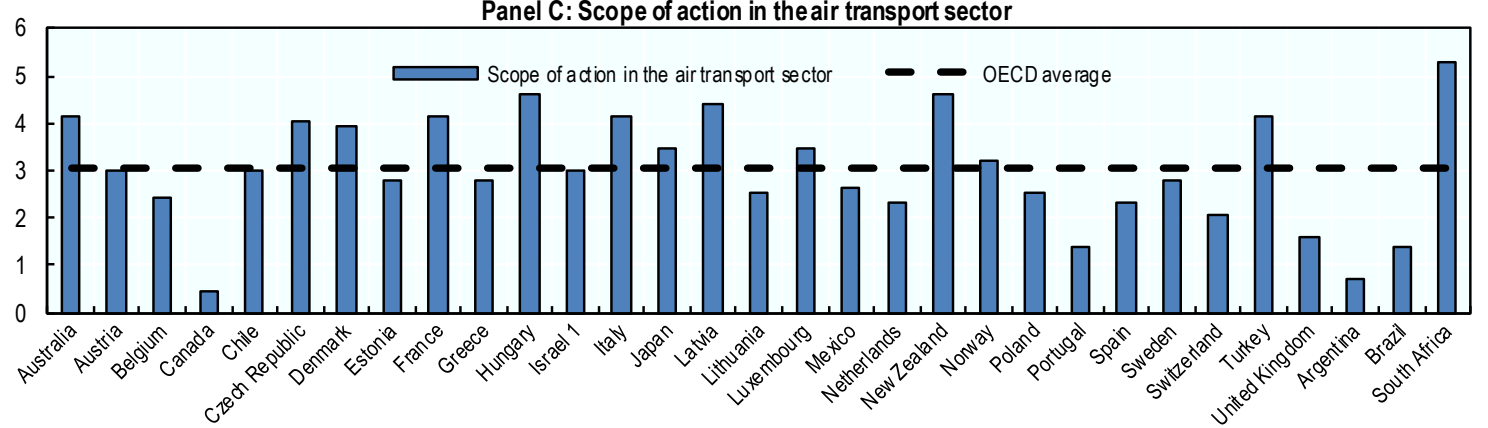

Notes: The indicators vary from zero to six from the most to the least effective governance structure.

The OECD average does not include Finland, Germany, Ireland, Korea, Slovenia, and the United States and excludes non-OECD members (Brazil, Argentina and South Africa).

1 The statistical data for Israel are supplied by and under the responsibility of the relevant Israeli authorities. The use of such data by the OECD is without prejudice to the status of the Golan Heights, East Jerusalem and Israeli settlements in the West Bank under the terms of international law.

Source: OECD 2018 Database on the Governance of Sector Regulators. 
Water

26. The results in Figure 6 focus on the scores of the water sector. The indicators for the water sector include fewer regulators as competencies for water and wastewater networks tend to also lie with sub-national authorities. Sub-national authorities are generally not captured in this analysis, as the survey is primarily oriented towards regulators operating at the national level. The water sector has independence and accountability scores mid-point across the entire sample (with a mean independence score of 1.83 and a mean accountability score of 1.81). The sector's high mean scope of action score (2.47) is second only to the score of the air sector. However, there is considerable variation between regulators in the scope of action section, ranging from the Israeli regulator's score of 0 to the Czech regulator's score of 4.04. 
Figure 6. The governance of regulators in the water sector

All countries and OECD average

Panel A: Independence in the water sector

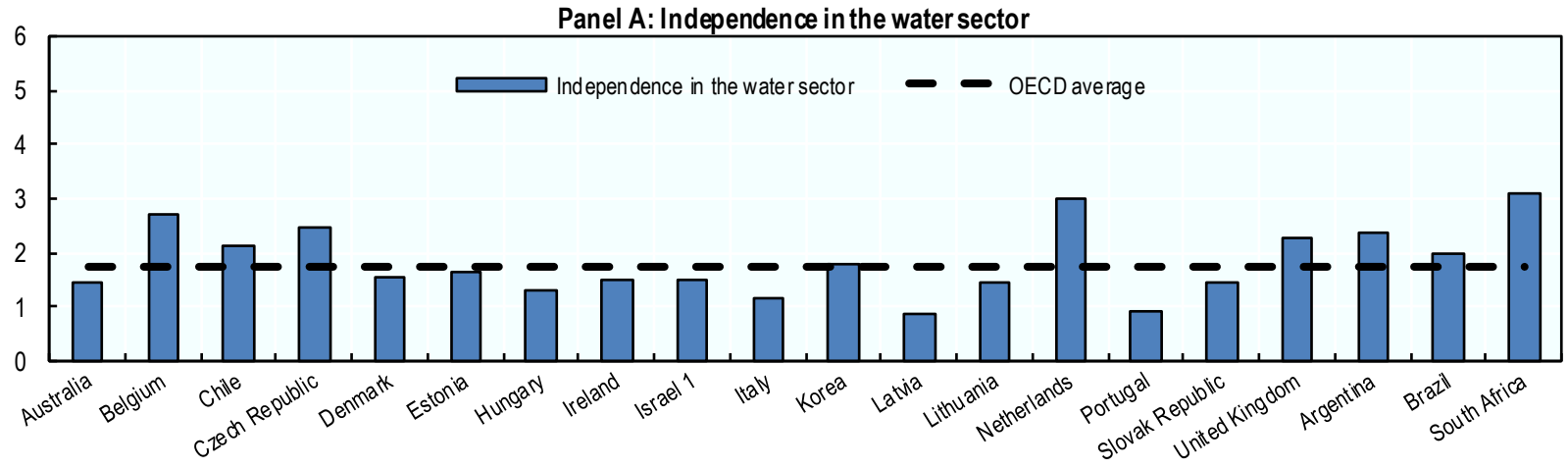

Panel B: Accountability in the water sector

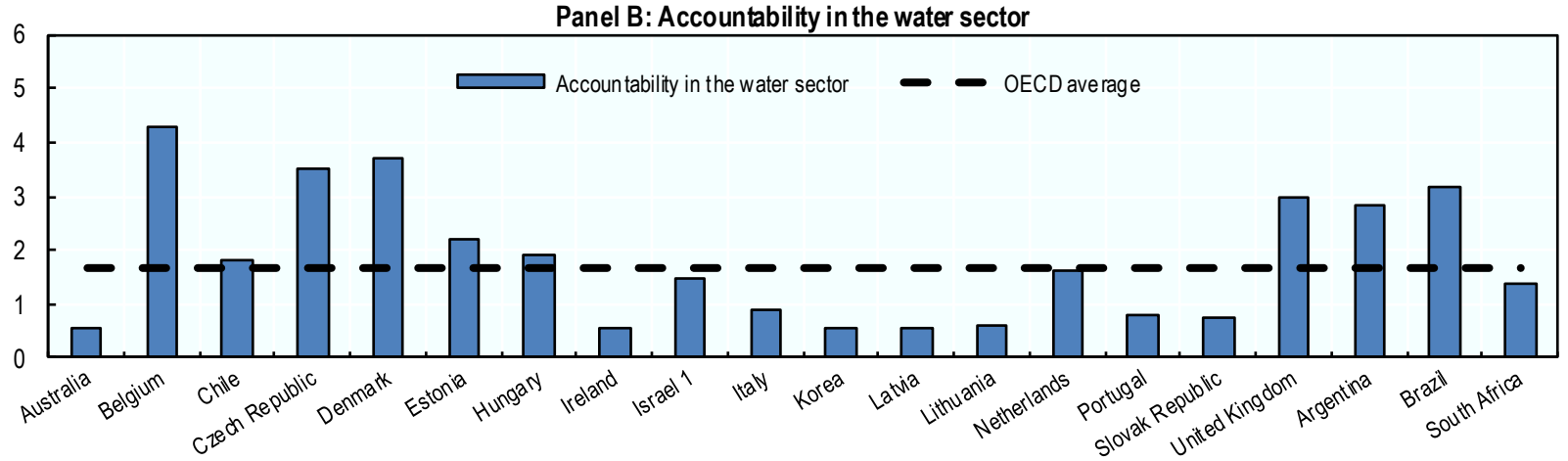

Panel C: Scope of action in thewater sector

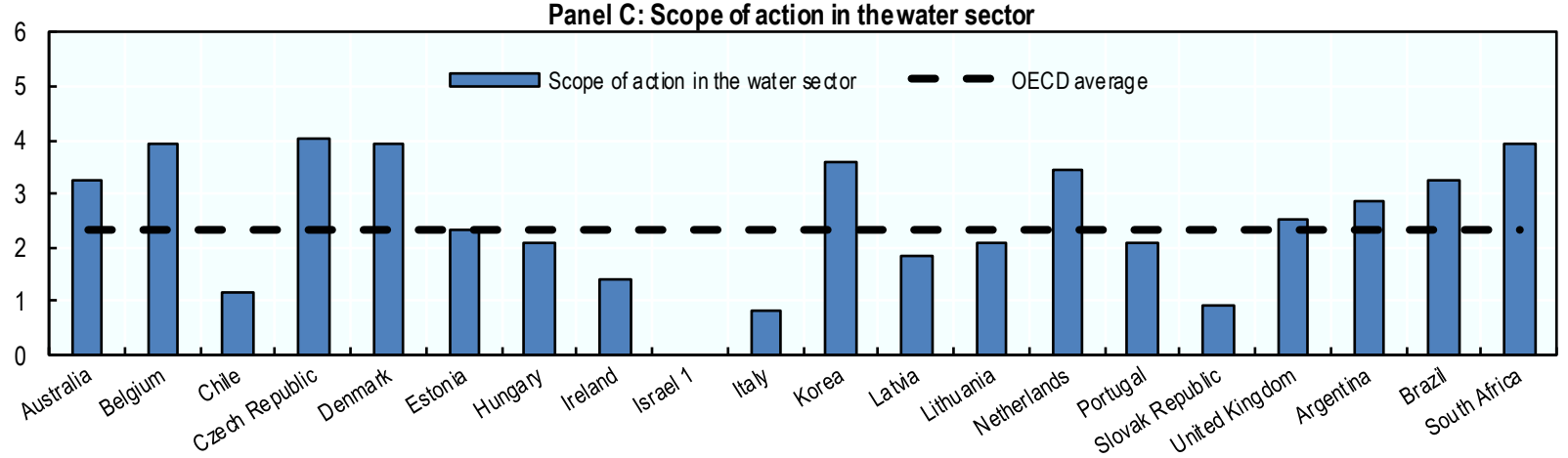

Notes: The indicators vary from zero to six from the most to the least effective governance structure.

The OECD average does not include Austria, Canada, Finland, France, Germany, Greece, Iceland, Japan, Luxembourg, Mexico, New Zealand, Norway, Poland, Slovenia, Spain, Sweden, Switzerland, Turkey and the United States and excludes non-OECD members (Brazil, Argentina and South Africa).

1 The statistical data for Israel are supplied by and under the responsibility of the relevant Israeli authorities. The use of such data by the OECD is without prejudice to the status of the Golan Heights, East Jerusalem and Israeli settlements in the West Bank under the terms of international law.

Source: OECD 2018 Database on the Governance of Sector Regulators. 


\subsubsection{Correlations}

27. The correlations between each component reveal some interesting patterns. First, there is no statistically significant relationship between the scope of action component and the other components, suggesting that the amount of functions and powers attributed to a regulator is not linked to its independence and accountability arrangements among surveyed countries.

Secondly, there is a positive association between independence and accountability scores that is statistically significant at the 0.05 level in all sectors (Figure 7). These results confirm the findings of the 2013 Product Market Regulation survey (Koske et al., 2016 $6_{[6]}$ ), indicating that, for sector regulators, greater autonomy is accompanied by stronger accountability structures. The correlation coefficients are particularly strong for regulators in the energy and e-communications sectors.

Figure 7. Relationship between independence and accountability scores

All countries by sector, using Spearman's rank correlation coefficient ${ }^{6}$
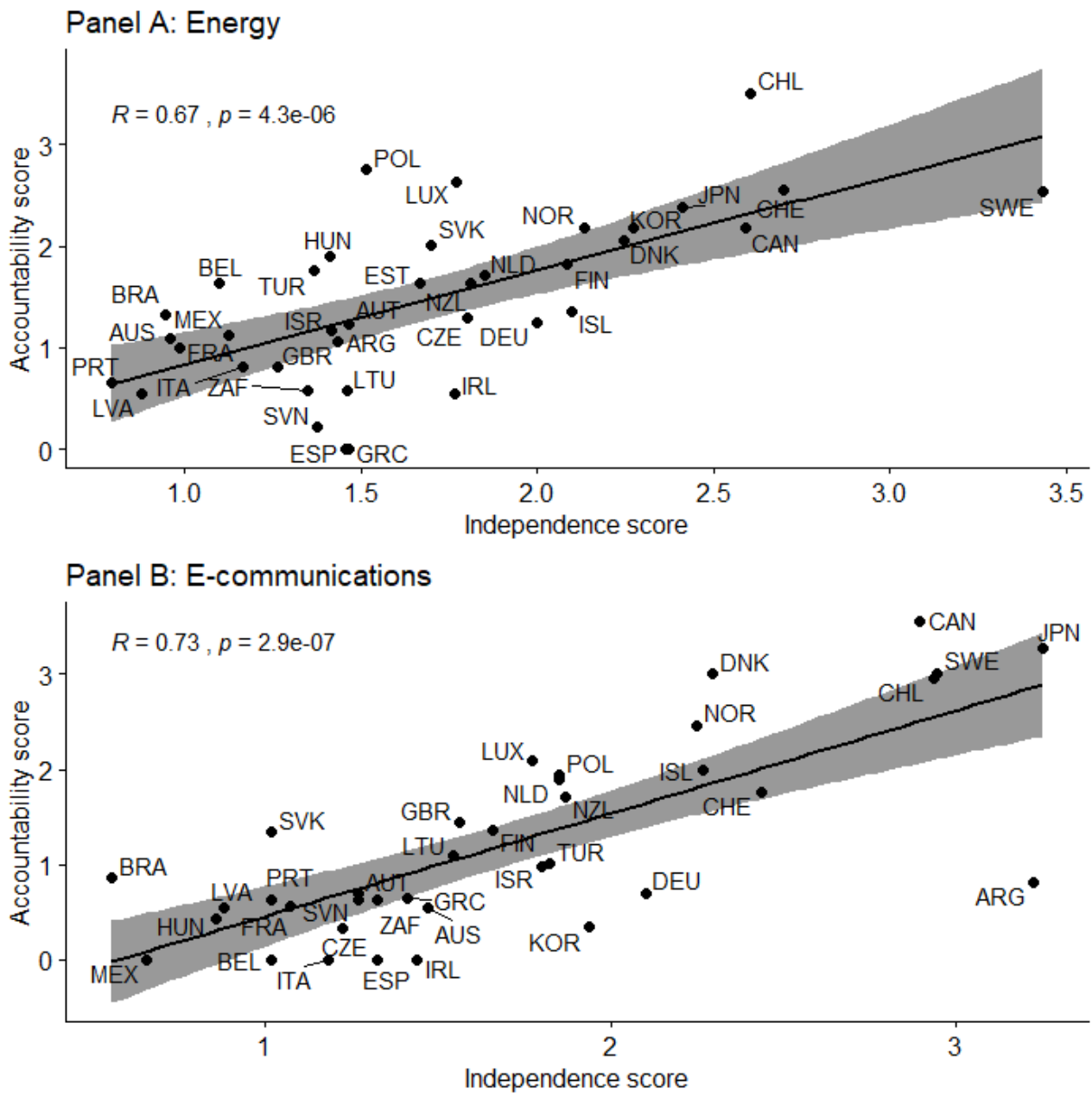

\footnotetext{
${ }^{6}$ Spearman's correlation coefficient, a non-parametric alternative to the Pearson product-moment correlation, measures the strength and direction of association between two continuous or ordinal variables.
} 


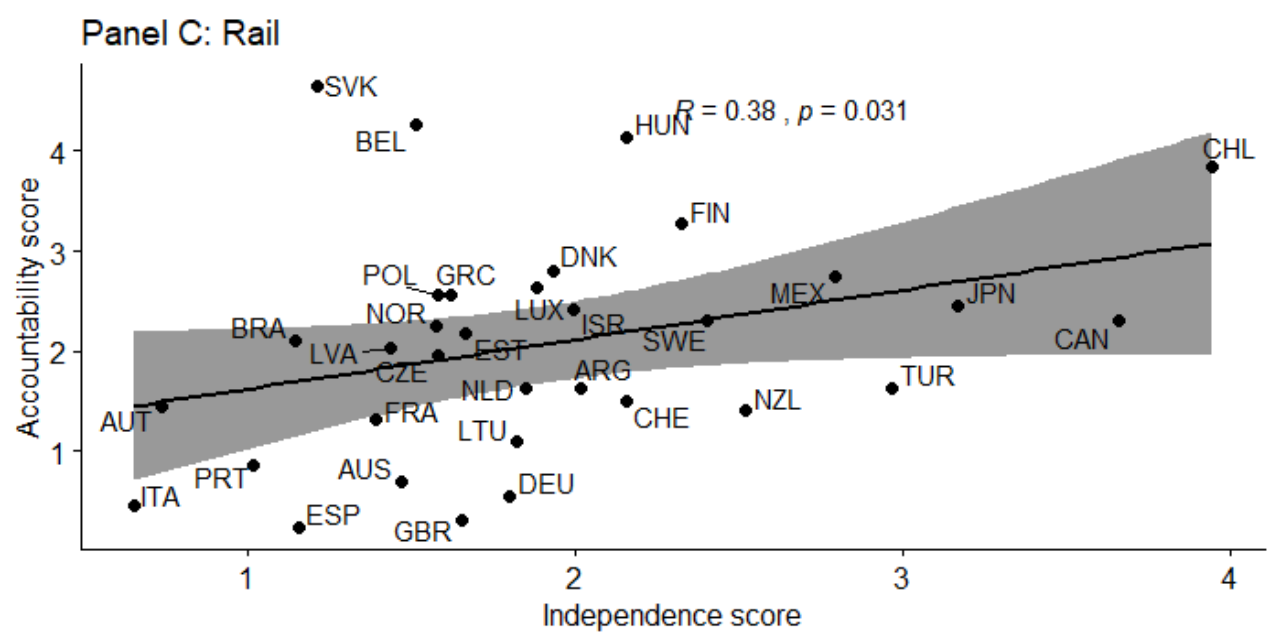

Panel D: Air
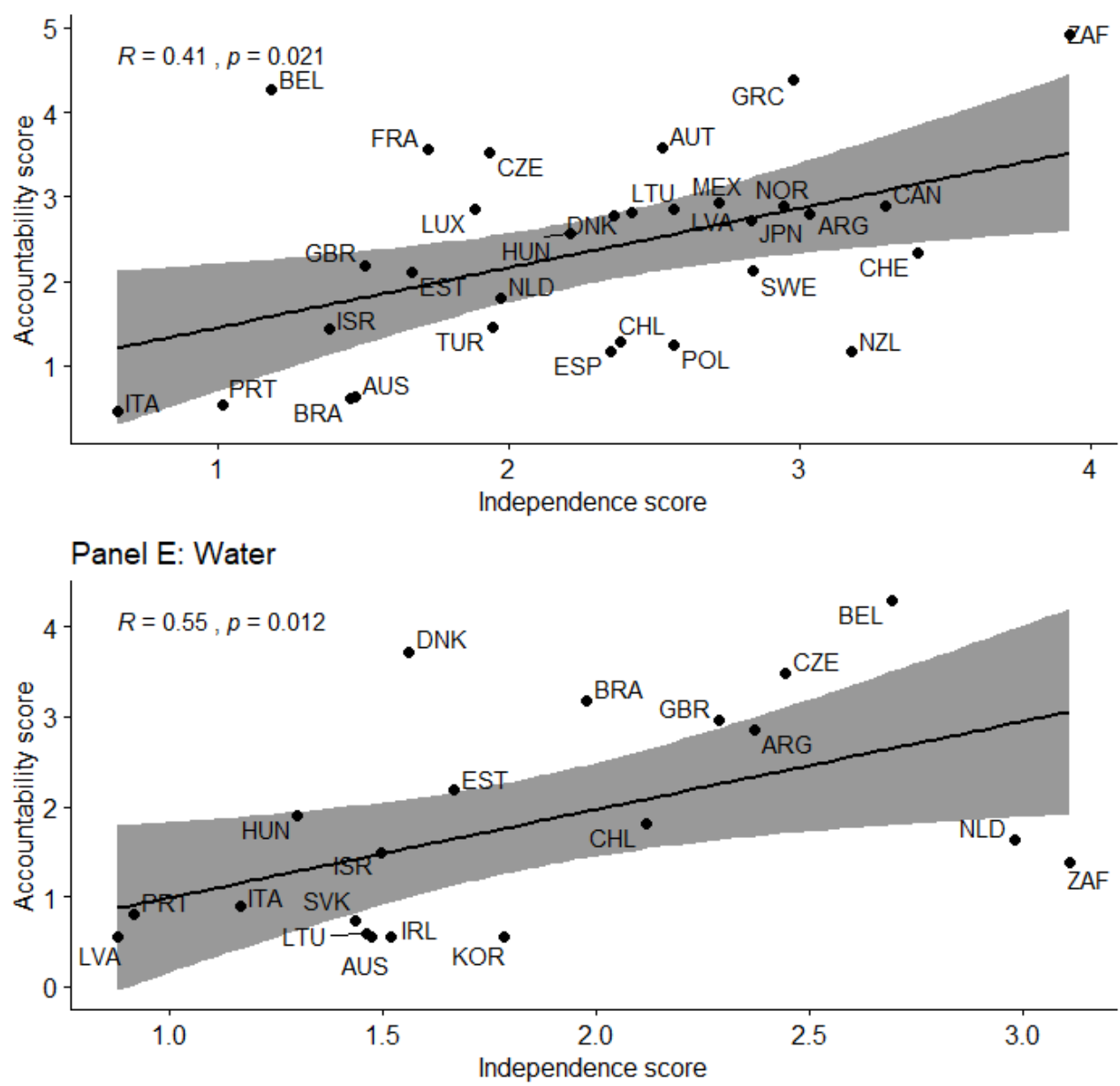

Notes: The indicators vary from zero to six from the most to the least effective governance arrangements. The reported score is an average of equally-weighted questions across the three components.

The statistical data for Israel are supplied by and under the responsibility of the relevant Israeli authorities Source: OECD 2018 Database on the Governance of Sector Regulators. 


\subsection{The independence of regulators}

28. This component maps the degree to which a regulator operates independently and with no undue influence from both the political power and the regulated sectors.

29. Fully mapping the determinants of independence across different market contexts is challenging; work recently developed by the NER provides a framework to better capture a wider array of elements that contribute to independence (OECD, 2016 $\left.6_{[7]}\right)$. As a result, the independence component captures the legal status of the regulator as well as some practical determinants of independence: relationship with the executive, staffing (including for the most senior positions), budget sources and spending autonomy.

Table 3. Summary statistics, independence component

All countries

\begin{tabular}{lrrrrr}
\hline & Energy & E-communications & Rail transport & Air transport & Water \\
\hline $\min$ & 0.79 & 0.56 & 0.66 & 0.66 & 0.88 \\
$\max$ & 3.43 & 3.25 & 3.94 & 3.93 & 3.11 \\
range & 2.64 & 2.69 & 3.29 & 3.27 & 2.23 \\
mean & 1.68 & 1.71 & 1.90 & 2.27 & 1.83 \\
std.deviation & 0.58 & 0.71 & 0.76 & 0.77 & 0.64 \\
\hline
\end{tabular}

Source: OECD Product Market Regulation Database.

\subsubsection{Legal status}

30. When asked to choose which of three choices best described their status "independent body with adjudicatory, rule-making or enforcement powers", "independent body with purely advisory role" and "ministerial department/agency" - the majority of regulators identified as independent bodies with adjudicatory, rule-making or enforcement powers.

31. Figure 8 shows that the energy sector has the highest share $(90 \%)$ of regulators in this category. The air sector displays a greater balance between independent bodies and ministerial bodies, with just over half of regulators identifying as independent bodies and the rest identifying as ministerial departments/agencies. This reflects the fact that several Civil Aviation Authorities are affiliated to Transport Ministries. 
Figure 8. Legal status of regulators

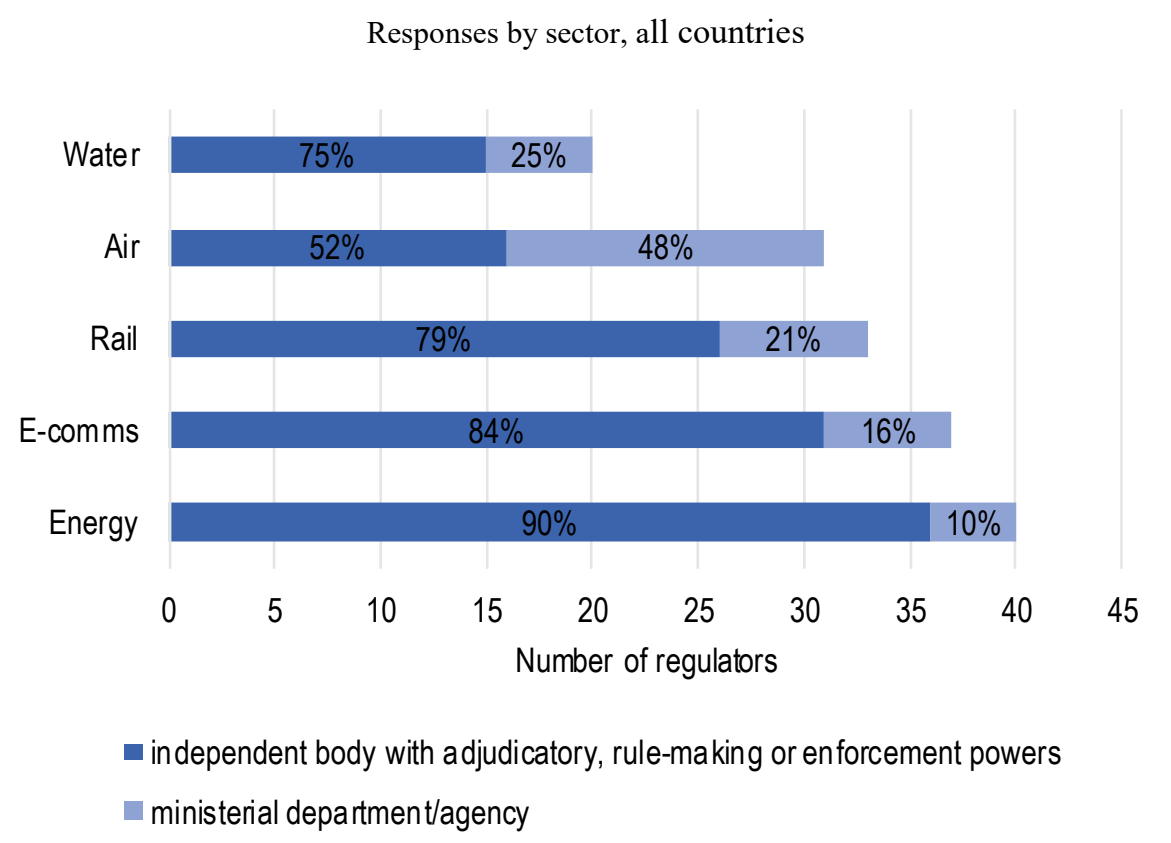

Source: OECD 2018 Database on the Governance of Sector Regulators.

Note: The bars depict the number of regulators who are either independent bodies or ministerial departments/agencies. The figures inside each bar denote the $\%$ of the sample within each sector that has each legal status.

32. Figure 9 shows that independent regulators are more common in countries that are members of the European Union (EU), with 12\% of regulators in EU Member States identifying as ministerial departments or agencies (compared with $39 \%$ of regulators in non-EU countries). Across all sectors, regulators classified as independent bodies outnumber ministerial regulators in EU countries. In the energy sector, all regulators are classified as independent.

33. A series of EU Directives have encouraged harmonisation in legal status in the energy and rail sectors across Member States. Directives 2009/72/EC and 2009/73/EC for the electricity and gas regulators mandate the creation of independent national regulatory authorities that are "legally distinct and functionally independent from any other public or private entity" in Article 35 and Article 39, respectively $\left(2009_{[8]} ; 2009_{[9]}\right)$. In the rail sector, Article 55 of the recast Directive 2012/34/EU specifies that each Member State shall establish a "stand-alone authority" distinct and independent from public and private entities, and includes new provisions related to the staffing and management of the regulatory bodies to safeguard their independence $\left(2012_{[10]}\right)$.

34. While EU Directives for the e-communications sector do not prescribe the legal status of regulators, Article 3 of Directive 2009/140/EC amending Framework Directive $2002 / 21 / E C$ for the telecommunications sector requires that national regulatory authorities "shall act independently and shall not seek or take instructions from any other body in relation to the exercise of these tasks assigned to them under national law implementing Community law" $\left(2009_{[11]}\right)$. The Directive also contains provisions as to the annual budget, the dismissal of the agency's head and other practical aspects of independence. 
Figure 9. The status of regulators in each sector, EU and non-EU countries

Panel A: The status of regulators in EU countries

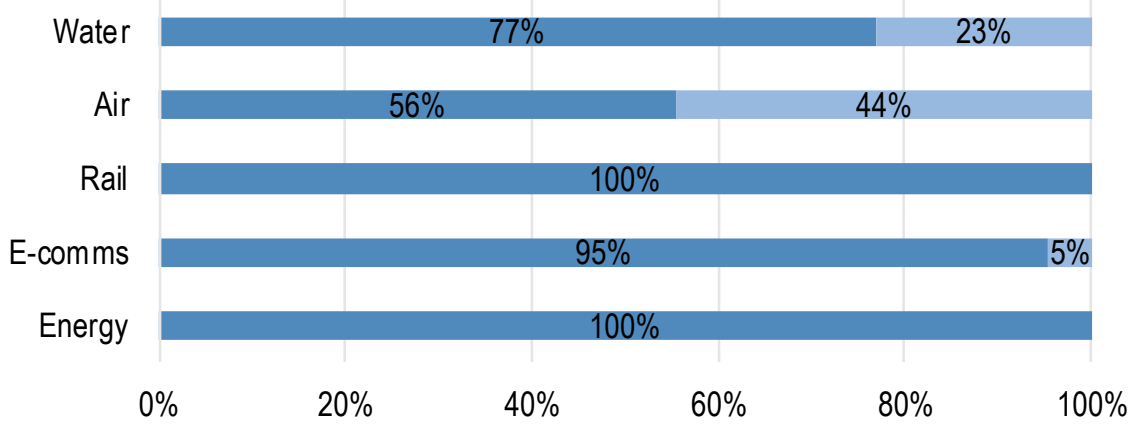

Panel B: The status of regulators in non-EU countries

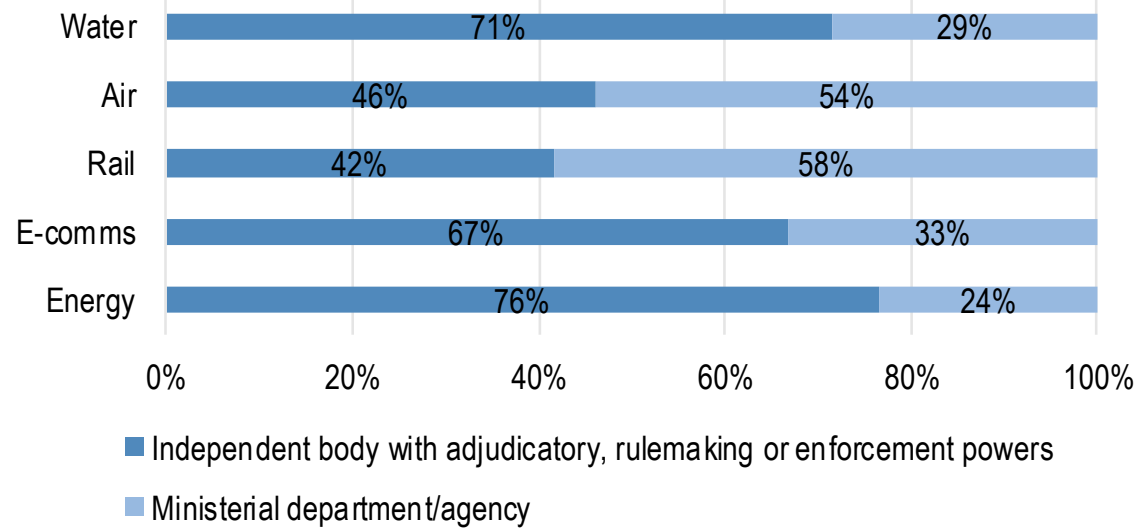

Source: OECD 2018 Database on the Governance of Sector Regulators.

35. OECD Council on Regulatory Policy and Governance guidance recommends that members develop policy that provides confidence that "regulatory decisions are made on an objective, impartial and consistent basis, without conflict of interest, bias or improper influence." It suggests that independent regulatory agencies may serve as a tool to improve confidence in regulatory decision-making under certain circumstances (OECD Council on Regulatory Policy and Governance, 2012 ${ }_{[1]}$ ). The distribution of independent and ministerial regulators across sectors in OECD countries mirrors the distribution across all countries.

36. Only three non-OECD countries are included in the dataset. Two out of three regulators in the e-communications, air and water sectors are independent (Figure 10). The two rail regulators ${ }^{7}$ in the non-OECD countries included are split evenly between the two categories. All of the non-OECD countries included have independent regulators in the energy sector.

\footnotetext{
${ }^{7}$ South Africa does not have an economic regulator for the rail sector.
} 
Figure 10. The status of regulators in each sector, OECD and non-OECD countries

\section{Panel A: The status of regulators in OECD countries}

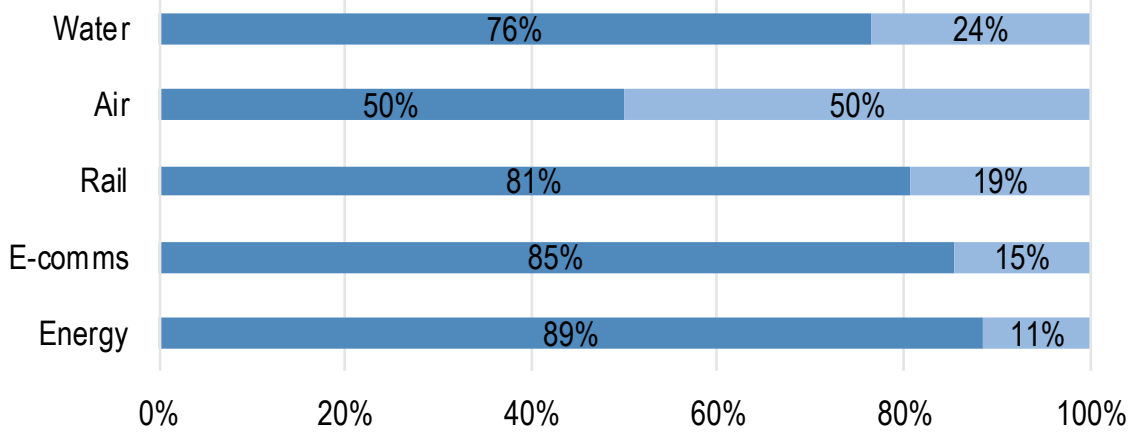

Panel B: The status of regulators in non-OECD countries

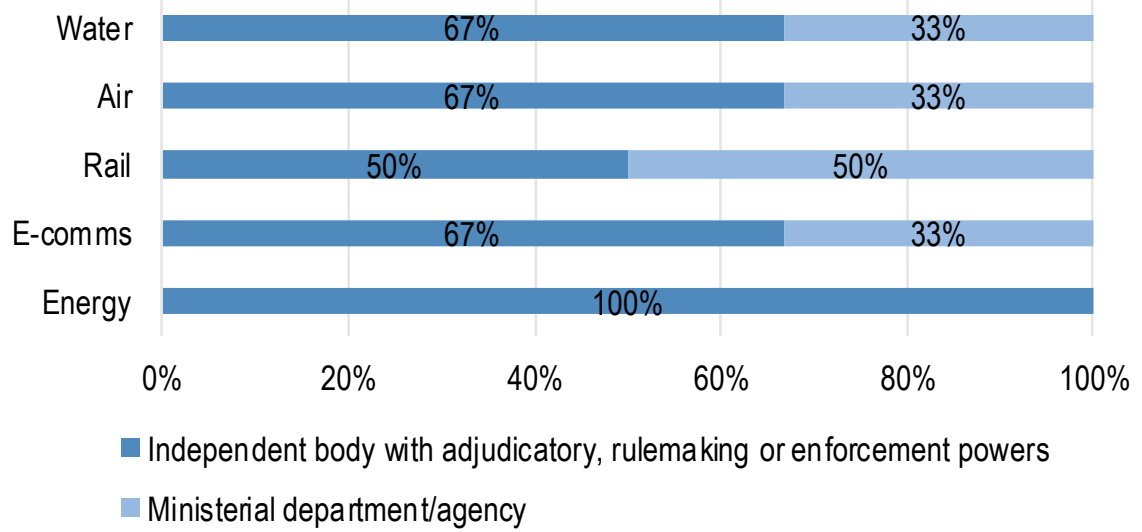

Source: OECD 2018 Database on the Governance of Sector Regulators.

\section{2,2, Relationship with the executive}

37. Designing regulators with a degree of formal independence from the executive can increase confidence in the impartiality of the regulator's decisions (OECD, 2014, p. 48 [2]). This subsection includes questions that gauge whether the regulator's objectives and functions are defined, whether the regulator can receive guidance from the executive on a range of outputs, and whether the regulator weighs in on legislation or policy proposed by the executive. In addition, it includes questions about the invalidation of decisions of the regulator.

38. The data show a wide variety of institutional arrangements relating to the regulator's relationship to the executive. All sectors have at least one regulator that adheres to all good practices in this subsection. The air sector shows the greatest diversity of these arrangements, with scores in this subsection ranging from zero to above four.

39. Establishing the objectives and functions of the regulator contributes to role clarity (OECD, 2014, p. $\left.31_{[2]}\right)$. The objectives and functions of all of the regulators are defined in some fashion, and the vast majority are defined in primary legislation (98\%). Only four regulators have objectives and functions defined in a policy document or a non-binding 
instrument (Sweden's energy regulator, Norway's e-communications and rail transport regulator, and New Zealand's air transport regulator).

40. To preserve independence from the executive, governance arrangements may limit executive involvement in certain actions and decisions (OECD, 2014 $\left.{ }_{[2]}\right)$. However, accepting executive guidance on long-term strategy ensures that the strategy is in line with broad strategic national priorities (Koske et al., 2016, p. 17 $7_{[6]}$ ).

41. Figure 11 shows that a large proportion of regulators appropriately receive guidance from the government regarding long-term strategy: nearly three-quarters of water and air regulators and around half of energy, e-communications and rail regulators. However, some regulators also receive government guidance on individual cases or regulatory decisions (ranging from 13\% in the energy sector to 39\% in the air sector), which departs from good practice for what concerns independent regulatory authorities. 
Figure 11. Regulators receiving guidance from the government

By sector, percent of all answers, all countries

Panel A: Long-term strategy

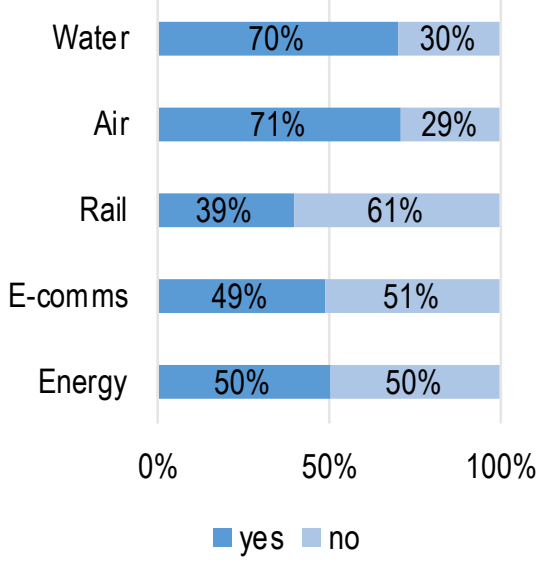

Panel C: Individual cases or regulatory decisions

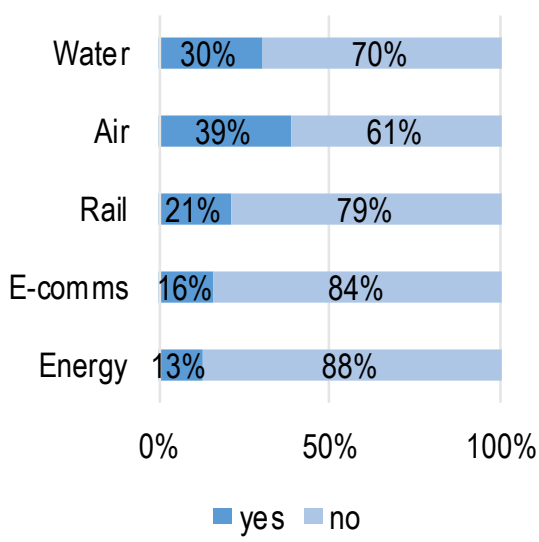

Panel B: Work programme

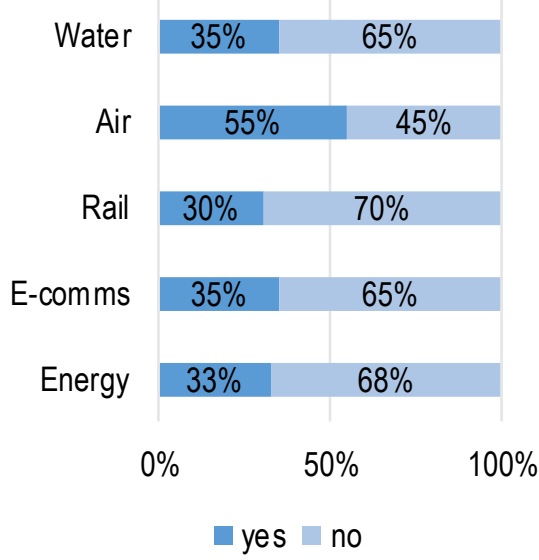

Panel D: Appeals

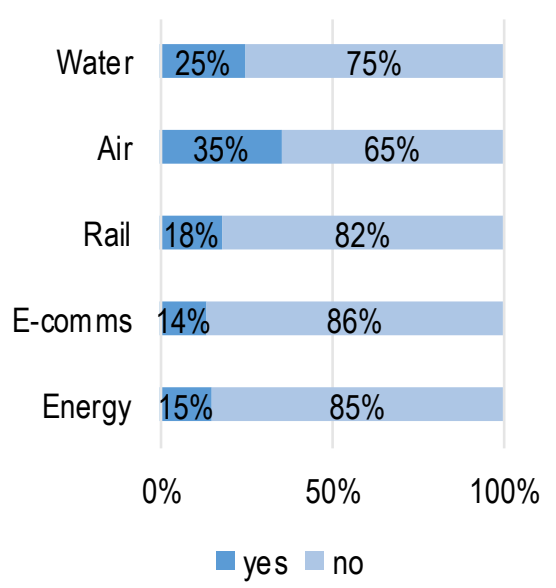

Source: OECD 2018 Database on the Governance of Sector Regulators.

42. When a regulator is located within a ministry, legislation prohibiting government from providing directions to a ministerial regulator about individual cases or regulatory decisions may be a particularly important guarantee of independence (OECD, 2014, p. $\left.52_{[2]}\right)$. This good practice is not largely reflected among the ministerial regulators surveyed, with the majority of those regulators in all sectors ( 3 of 4 in the energy sector, 4 of 6 in e-communications, 5 of 7 in rail transport, 9 of 15 in air transport and 4 of 5 in the water sector) reporting that they do accept guidance from the government regarding individual cases or regulatory decisions.

43. Independent institutions may suffer from reduced space to influence government policy and the legislative process than the rest of public administration (Zemanovicova and Holienka, 2017 $[12])$. However, regulators can offer substantial expertise and advice that can 
improve the quality of new policies and laws. As shown in Table 4, most regulators make recommendations or issue opinions on draft legislation or policy documents.

Table 4. Number of regulators issuing opinions on draft legislation or policy documents

\begin{tabular}{|c|c|c|c|c|c|c|}
\hline & Energy & E-comms & Rail & Air & Water & Total \\
\hline Yes (through a formal process \& opinion made public) & 28 & 28 & 21 & 15 & 11 & 103 \\
\hline Yes (through a formal or informal process but opinion not made public) & 10 & 6 & 10 & 7 & 7 & 40 \\
\hline No & 2 & 3 & 2 & 9 & 2 & 18 \\
\hline
\end{tabular}

Source: OECD 2018 Database on the Governance of Sector Regulators.

44. In most cases, only a court can overturn regulators' decisions, suggesting a high degree of independence while ensuring that judicial review is available to regulated entities, a good practice to enhance the accountability of regulatory decisions (Figure 12). However, specialised bodies such as administrative tribunals are most common in the water and energy sectors, where 20 and $18 \%$ of regulators respectively report that their decisions can be overturned by a specialised body with greater technical expertise than judicial appeal bodies. Legislation usually defines the cases in which governmental bodies can overturn regulator's decisions. Typically decisions related to tariff-setting cannot be overturned, while rule-making activities may require ministerial approval and can be invalidated by the executive.

Figure 12. Bodies other than a court that can overturn regulators' decisions

By sector, percent of all answers, all countries

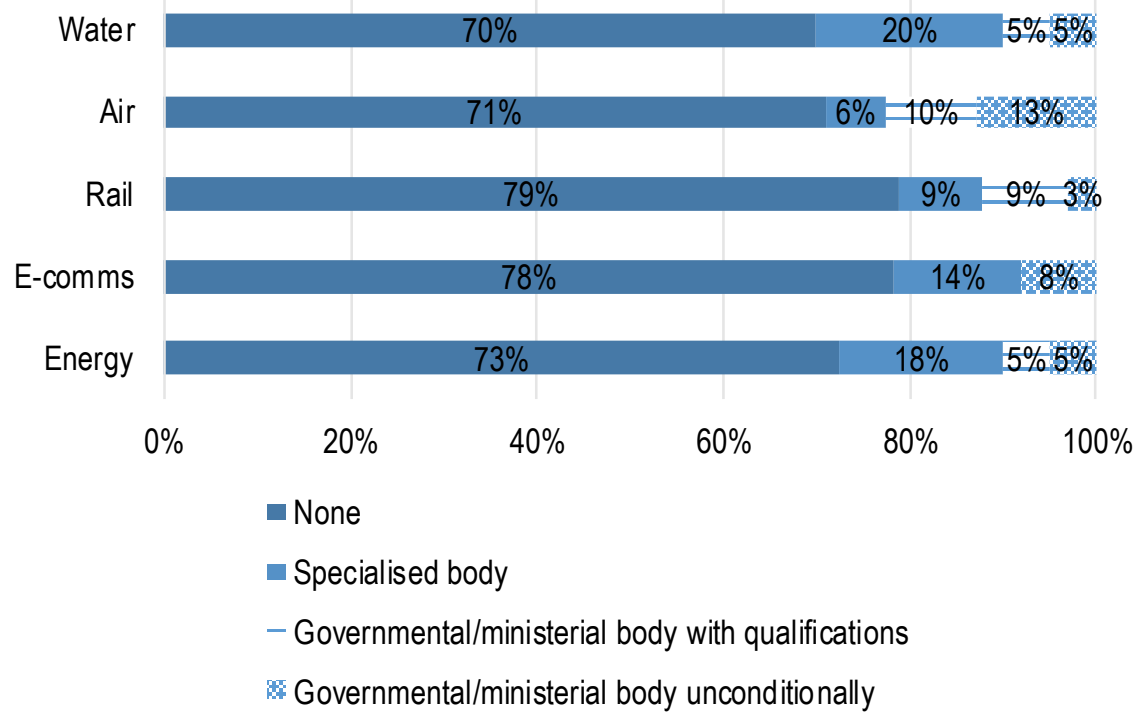

Source: OECD 2018 Database on the Governance of Sector Regulators.

\subsubsection{Staff}

45. Governance arrangements can limit the possibility of actual or perceived influence on staff members (Koske et al., 2016, p. $54_{[6]}$ ). This subsection investigates the employment arrangements of agency heads or board members (and to a lesser extent, other 
staff) of a regulator before their nomination, during their nomination and appointment, during their tenure and after their departure.

46. Overall, the results point to roughly similar arrangements across sectors; however, regulators in the air sector tend to reflect good practices for staffing less than regulators in the other sectors.

47. The majority of the regulators in the energy, e-communications, rail transport, and water sectors are led by boards (Figure 13). A slight majority of air transport regulators $(55 \%)$ are led by an agency head.

Figure 13. Regulator's leadership

By sector, percent of all answers, all countries

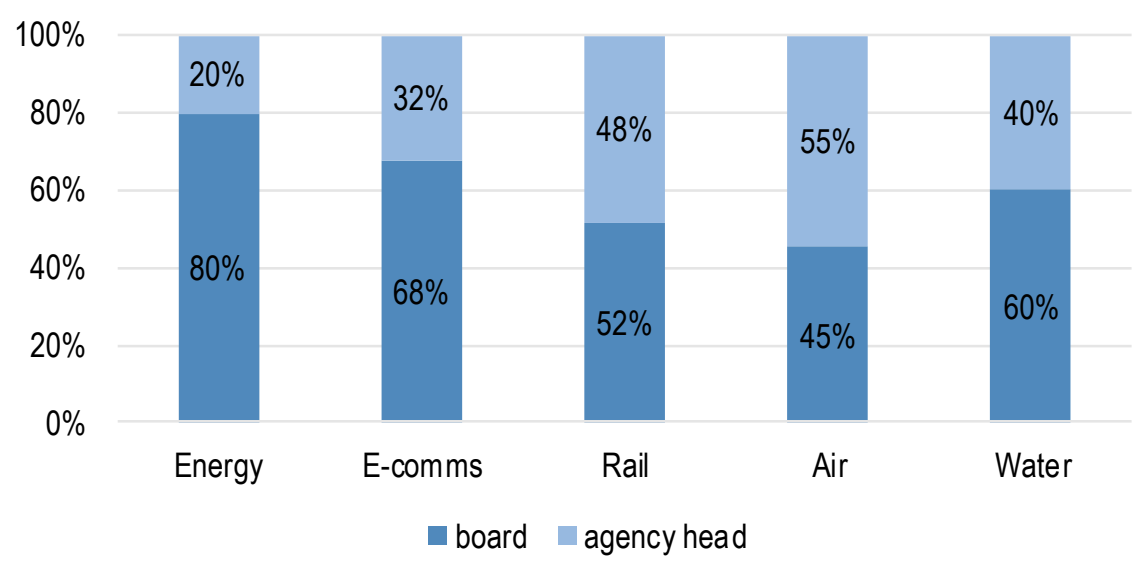

Source: OECD 2018 Database on the Governance of Sector Regulators.

48. Governance arrangements should allow regulators to attract expertise and talent to serve as leadership while minimising the risk of a "revolving door" between regulatory and industry or government (Koske et al., 2016, p. 15 $5_{[6]}$ ). Restrictions based on past employment for serving as regulator leadership are uncommon. Fewer than half of the regulators in all sectors $(35 \%$ in the energy sector, $46 \%$ in the e-communications sector, $45 \%$ in the rail transport sector, $29 \%$ in the air transport sector, and $35 \%$ in the water sector) have restrictions in place regarding the employment history of the agency head or board members. The leadership of most regulators cannot accept other positions during their tenure $(85 \%$ in the energy sector, $89 \%$ in the e-communications sector, $88 \%$ in the rail transport sector, $81 \%$ in the air transport sector and $75 \%$ in the water sector).

49. In most independent regulators, leadership is restricted from accepting jobs in the government and/or the regulated sector after their term of office, in line with good practice principles suggesting that top decision-makers should be protected from undue influence (OECD, 2014, p. 72 ${ }_{[2]}$ ) (Figure 14). A cooling-off period is the most common restriction, with more than half of regulators in all sectors reporting that they have this restriction in place. Having no post-employment restrictions is most common in the energy sector, where around a third of regulators do not have any such restrictions. 
Figure 14. Among independent regulators, can the agency head/board members accept jobs in the government and/or the regulated sector after their term of office?

By sector, percent of all answers, all countries

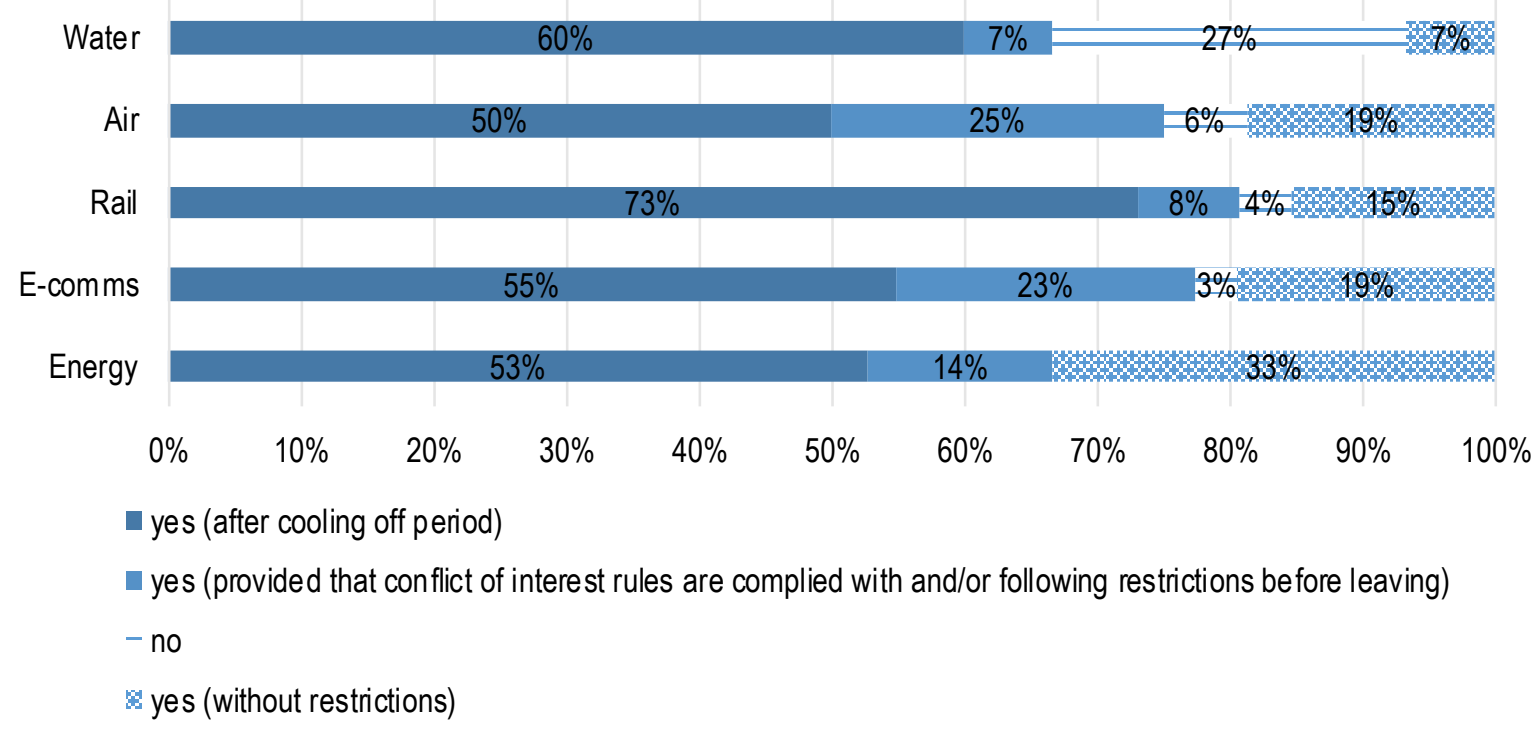

Source: OECD 2018 Database on the Governance of Sector Regulators.

50. Across all sectors, the agency head or board members in most regulators can be dismissed through government decisions (Figure 15). A relatively small proportion of agency heads or board members can be dismissed from office through court procedure or through parliamentary decisions. Several regulators have unique arrangements in place for the dismissal of board members. For example, board members of the French energy, ecommunications and rail regulators can be dismissed by other board members ${ }^{8}$.

51. In most sectors, a limited and defined set of criteria for the dismissal of agency heads or board members are in place for the majority of regulators $(78 \%$ of energy regulators, $76 \%$ of e-communications regulators, $76 \%$ of rail transport regulators and $70 \%$ of water regulators). The air sector is the exception; in this sector, less than half of regulators $(39 \%)$ report that these criteria are in place.

\footnotetext{
${ }^{8}$ The French law on the general status of independent administrative authorities and independent public authorities (2017[13]) stipulates that a three-quarter majority of the board may vote to suspend a board member's mandate if they consider the member is in serious breach of their legal obligations or if the member has a definitive incapacity that will prevent them from completing their mandate.
} 
Figure 15. How can the agency head/board members be dismissed from office?

By sector, percent of all answers, all countries

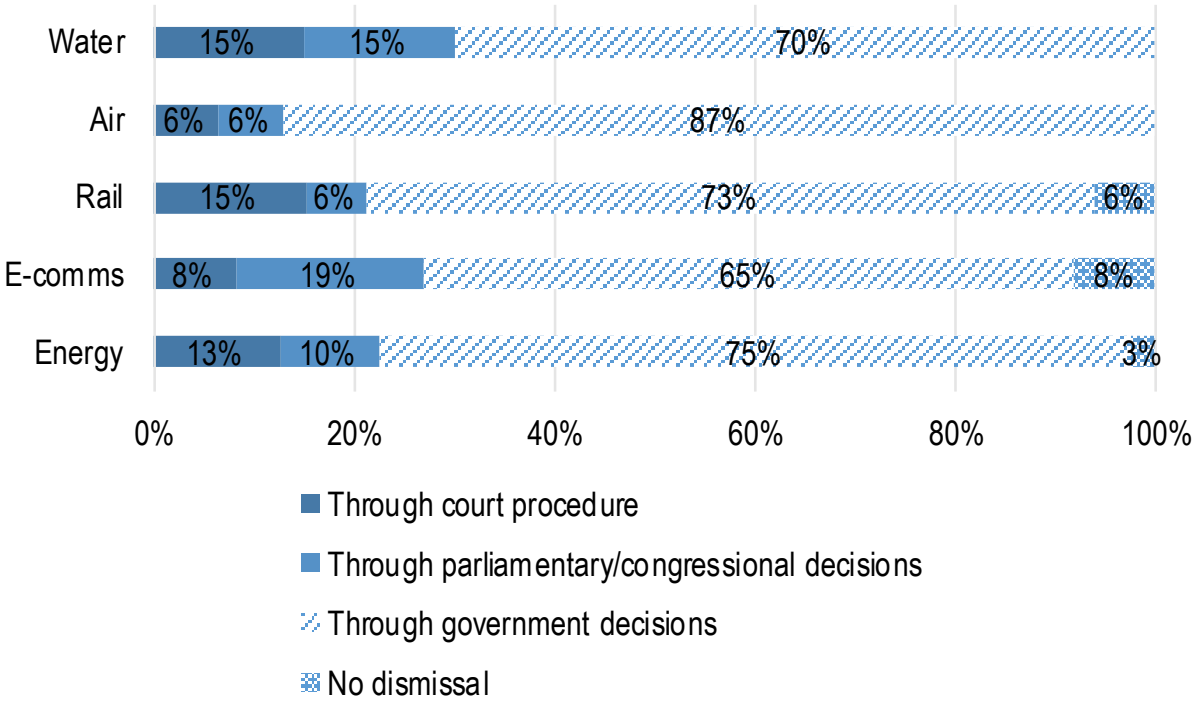

Source: OECD 2018 Database on the Governance of Sector Regulators.

\subsubsection{Budget}

52. The budget subsection includes questions about the source of the financial budget of the regulator, the length of budget appropriations and the process of setting fees or receiving budget appropriations. The subsection also asks which body is responsible for deciding how the regulator's expenditures are allocated.

53. The means of the budget subsection scores are similar across all of the sectors. In most sectors, roughly equal proportions of regulators are financed through fees alone, state budget appropriations alone or a combination (Figure 16). This reflects a mix of historical arrangements as well as ability of the regulated sector to contribute to the funding of the regulator, depending on industry revenues and volumes. In the energy sector, more regulators are funded by fees only (35\%) than by state budgets only $(28 \%)$. In the water sector, only $15 \%$ of water regulators receive funding from a combination of fees and budget. 
Figure 16. Regulators funded through budget appropriations, fees or both By sector, percent of all answers, all countries

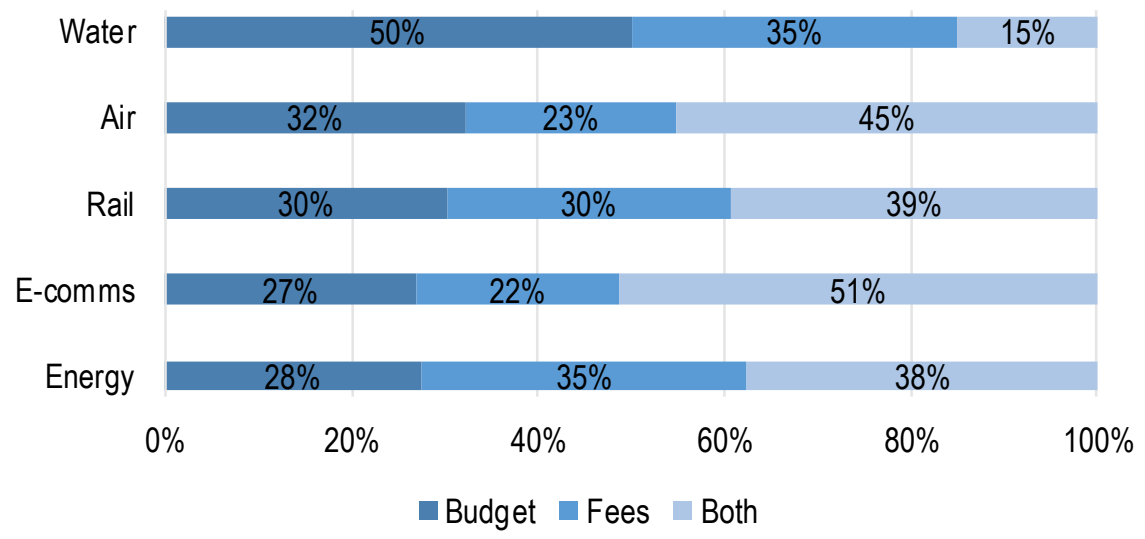

Source: OECD 2018 Database on the Governance of Sector Regulators.

54. It is worthwhile cross-referencing the emerging evidence from the broader OECD PMR Indicators and the Indicators on the Governance of Sector Regulators to scan for any relationships between the two. Of particular interest may be the relationship between government-owned firms in one sector and the independence arrangements of the regulator overseeing the same sector.

55. Table 5 shows the mean independence scores of regulators in the energy sector in countries with and without government majority stakes in the largest firm in electricity generation, import, transmission, distribution and retail supply. Where government has a majority stake, energy regulators have a higher mean independence score than that of energy regulators in countries where governments do not have a majority stake (Table 5). A priori, independence provisions should be stronger to insulate the regulator from potential pressures coming from the executive when the government is the majority shareholder of the regulated firm.

Table 5. Energy sector mean independence scores for countries where national, state, regional provincial or municipal governments hold $\geq \mathbf{5 0 \%}$ equity stakes in the largest firm

All countries

\begin{tabular}{lrr}
\hline & $\begin{array}{c}\geq 50 \% \text { equity stakes } \\
\text { in the largest firm }\end{array}$ & $\begin{array}{c}<50 \% \text { equity stakes in } \\
\text { the largest firm }\end{array}$ \\
\cline { 2 - 3 } Generation & 1.71 & 1.59 \\
Import & 1.57 & 1.56 \\
Transmission & 1.70 & 1.61 \\
Distribution & 1.72 & 1.60 \\
Retail supply & 1.77 & 1.58 \\
\hline
\end{tabular}

Note: Argentina and Brazil have two separate regulators, one for electricity and one for gas. The average independence scores above exclude the scores for the two gas regulators.

Source: OECD Product Market Regulation Database, OECD 2018 Database on the Governance of Sector Regulators. 


\subsection{The accountability of regulators}

56. This component covers the accountability of the regulator vis-à-vis various stakeholders, including the government, parliament, the regulated industry and citizens. This component also captures the adherence to compliance and accountability instruments such as regulatory management tools and the collection, use, publication and reporting of performance information, all of which enhance the transparency and provide scrutiny of regulators' actions.

Table 6. Summary statistics, accountability component

\begin{tabular}{lrrrrr}
\hline & Energy & E-communications & Rail transport & Air transport & \multicolumn{1}{l}{ Water } \\
\hline Min & 0.00 & 0.00 & 0.23 & 0.45 & 0.55 \\
Max & 3.51 & 3.55 & 4.64 & 4.91 & 4.29 \\
range & 3.51 & 3.55 & 4.40 & 4.45 & 3.74 \\
mean & 1.47 & 1.22 & 2.07 & 2.35 & 1.81 \\
std.deviation & 0.81 & 1.01 & 1.12 & 1.17 & 1.22 \\
\hline
\end{tabular}

Source: OECD 2018 Database on the Governance of Sector Regulators.

57. The results indicate that a majority of regulators are accountable to the executive in most sectors (Figure 17). The 2018 results are similar to those of 2013; however, in the case of e-communications regulators there has been a shift with a majority of agencies accountable to parliament/congress (in 2018) rather than the executive (as was the case in 2013). In the water sector, which was not surveyed in 2013, the proportions of regulators accountable to the executive and parliament or congress are equivalent to those of the energy sector, as often the same regulator is in charge of both sectors.

Figure 17. To whom is the regulator directly accountable by law or statute?

By sector, percent of all answers, all countries

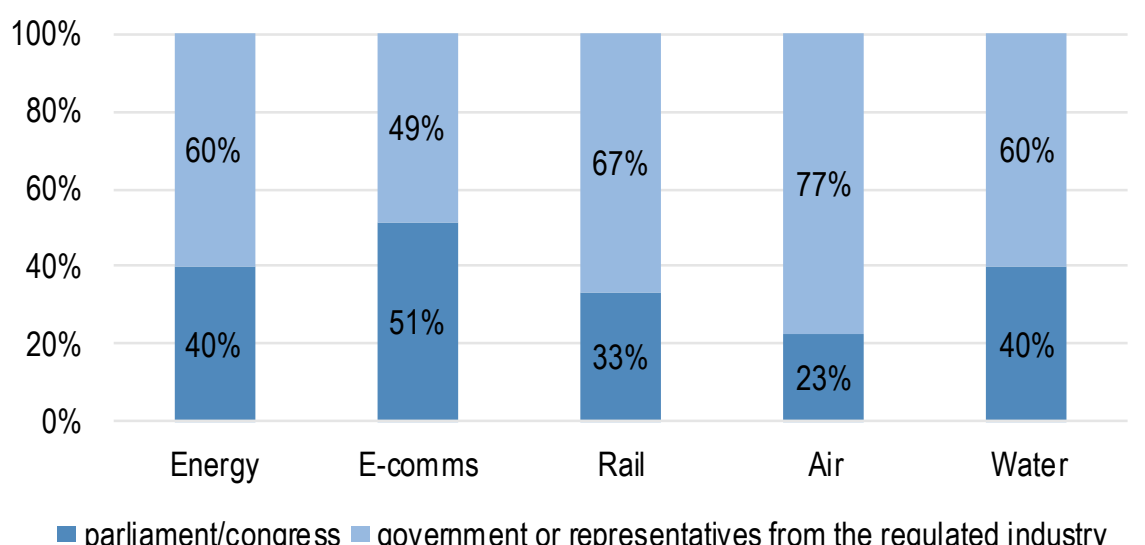

Source: OECD 2018 Database on the Governance of Sector Regulators.

58. Engaging with stakeholders offers a range of benefits, including enhancing trust and transparency $\left(\mathrm{OECD}, 2012_{[13]}\right)$. The largest share of regulators in all sectors is bound 
by legislative requirements to publish draft decisions and collect feedback from stakeholders (Figure 18). Many regulators publish draft decisions for comment even in the absence of a legislative requirement. However, more than one-quarter of regulators in the rail and air sectors do not publish draft decisions for comment. Almost all of the regulators who publish their draft decisions for comment also provide feedback on comments received from stakeholders ( $91 \%$ of energy regulators, $100 \%$ of e-communications regulators, $100 \%$ of rail transport regulators, $96 \%$ of air transport regulators and $88 \%$ of water regulators).

Figure 18. Does the regulator publish draft decisions and collect feedback from stakeholders?

By sector, percent of all answers, all countries

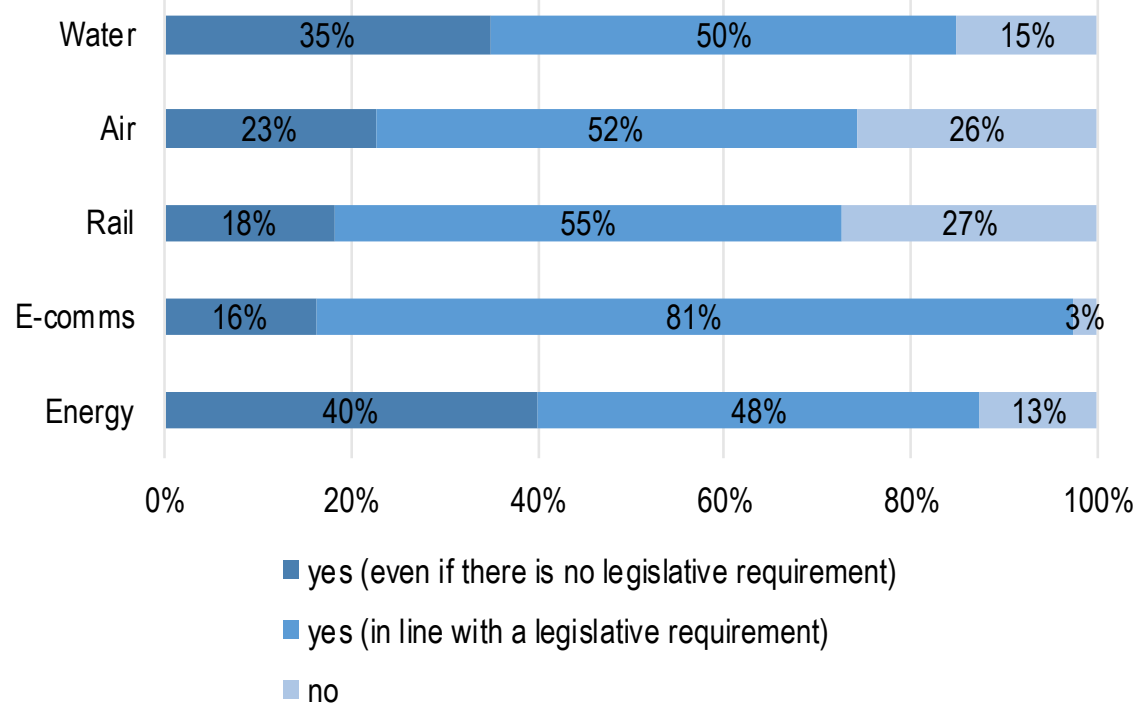

Source: OECD 2018 Database on the Governance of Sector Regulators.

59. Most regulators collect information about the financial performance of the regulator, its compliance with legal obligations, the quality of its regulatory process, its organisational/corporate governance performance, its operational service delivery, its economic performance and the industry and market performance of the regulated sector (Figure 19). Collecting information about the regulators financial performance and the industry and market performance of the regulated sector is most common, while collecting information about the regulator's compliance with legal obligations and quality of regulatory processes is least common. Making this information publicly available enhances the legitimacy and improves public perception of regulatory agencies. 
Figure 19. What types of performance information does the regulator collect?

Percent of all answers, all countries

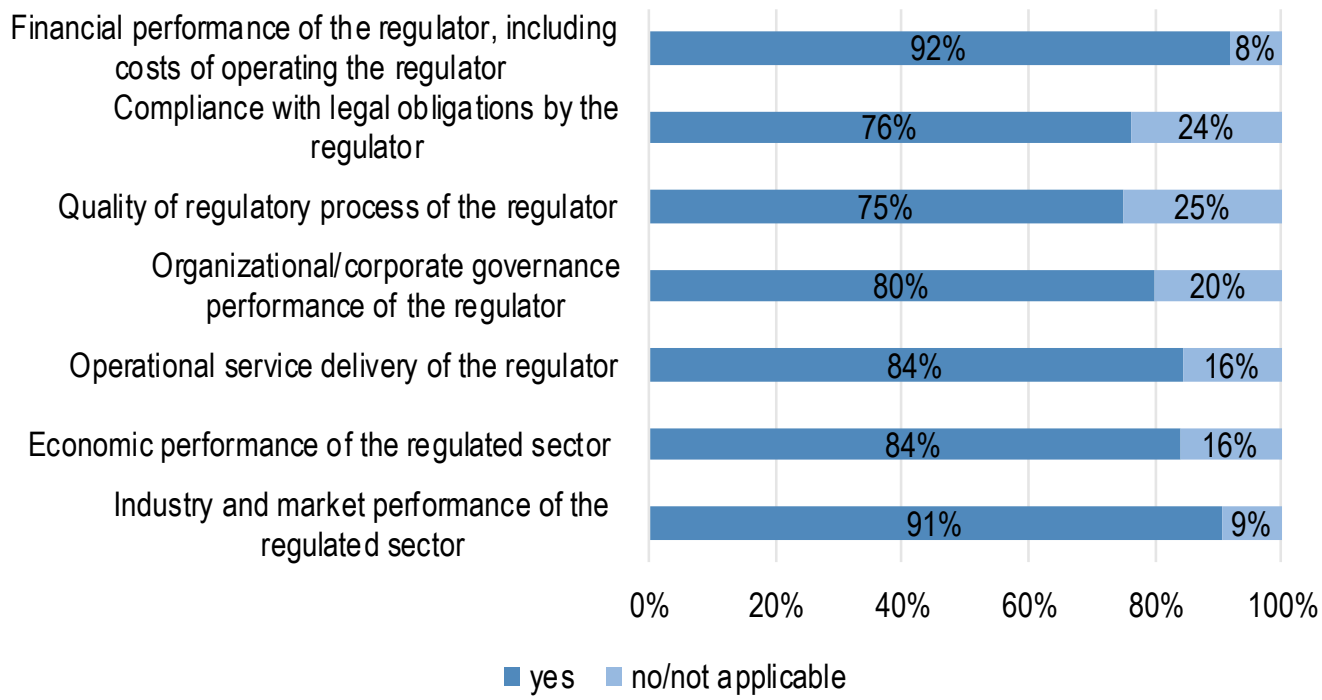

Source: OECD 2018 Database on the Governance of Sector Regulators.

60. Out of the regulators collecting performance information, most publish this information online (Figure 20). Fewer regulators publish information about compliance with legal obligations by the regulator $(76 \%)$ and quality of regulatory processes of the regulator $(75 \%)$, relative to the other categories of performance information.

Figure 20. Among regulators who collect performance information, is the information published on the regulator's website?

Percent of all answers, all countries

Financial performance of the regulator, including costs of operating the regulator Compliance with legal obligations by the regulator

Quality of regulatory process of the regulator

Organizational/corporate governance performance of the regulator

Operational service delivery of the regulator

Economic performance of the regulated sector

Industry and market performance of the regulated sector

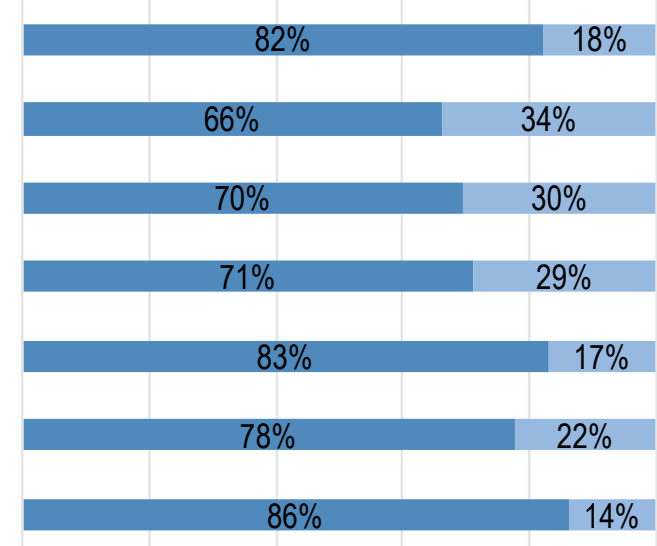

$0 \% \quad 20 \% \quad 40 \% \quad 60 \% \quad 80 \% \quad 100 \%$
yes no

Source: OECD 2018 Database on the Governance of Sector Regulators. 


\subsection{The scope of action of regulators}

61. This component sheds light on the range of activities that the regulator performs, including tariff-setting, issuing standards, enforcement activities and sanctioning powers. Unlike the independence and accountability components, the quantity of functions that regulators have does not necessarily translate into higher quality. Therefore, better scope of action scores do not indicate better governance arrangements. However, this component is useful to gauge key differences between sectors and countries for what concerns the remit of regulatory authorities.

Table 7. Summary statistics, scope of action component

\begin{tabular}{lcrrrr}
\hline & Energy & E-communications & Rail transport & Air transport & Water \\
\hline $\min$ & 0.23 & 0.00 & 0.46 & 0.46 & 0.00 \\
$\max$ & 4.15 & 3.00 & 3.69 & 5.31 & 4.04 \\
range & 3.92 & 3.00 & 3.23 & 4.85 & 4.04 \\
mean & 1.43 & 1.05 & 2.20 & 3.01 & 2.47 \\
std.deviation & 1.03 & 0.70 & 0.83 & 1.18 & 1.20 \\
\hline
\end{tabular}

Source: OECD 2018 Database on the Governance of Sector Regulators.

62. Regulators are empowered to conduct a range of activities independently, although a minority of regulators cooperate with other agencies or bodies. Of the activities presented in Figure 21, the least common activities for regulators to report are issuing consumer standards (with only $49 \%$ reporting that they issue these standards independently or with another body) and issuing industry standards (with only $42 \%$ issuing these standards). Many more regulators enforce standards (78\%), most commonly set by government and parliament. This shows that only a limited number of regulators enforce standards that they set themselves. A version of Figure 21 with data separated by sector can be found in Annex E. 


\section{Figure 21. Which activities can regulators engage in?}

Percent of all answers, all countries

Does the regulator have the power to take final decisions in disputes between market actors and regulated entities?

Does the regulator mediate to resolve disputes between market actors and regulated entities?

Does the regulator enforce compliance with industry and consumer standards and regulatory commitments through legal punitive powers for non-compliance (e.g. inspections and fines)?

Does the regulator issue guidelines and/or codes of conduct?

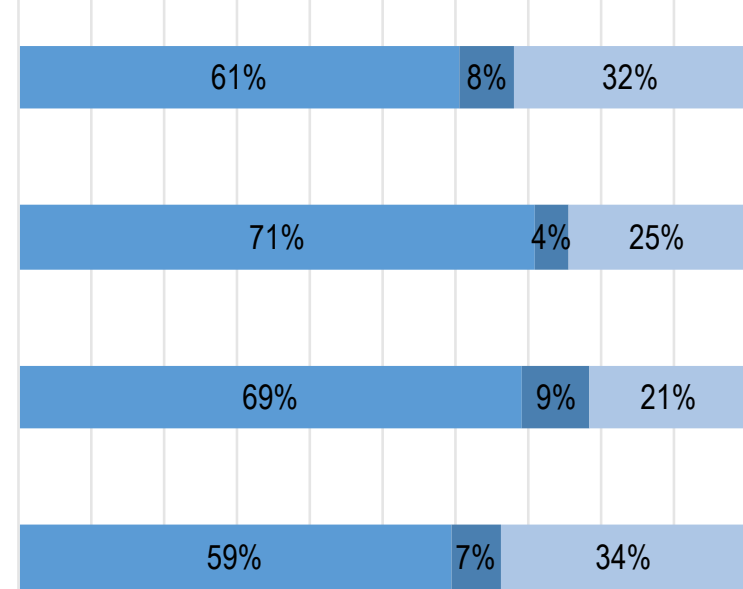

Does the regulator issue consumer standards?

Does the regulator issue industry standards?

Does the regulator provide binding guidance, review and/or approve contract terms between regulated entities and/or market actors?

Does the regulator conduct research (e.g. about costs) as an input for price setting?

Does the regulator regulate monopoly prices?

Does the regulator issue and revoke licenses and/or can deny or revoke authorisations
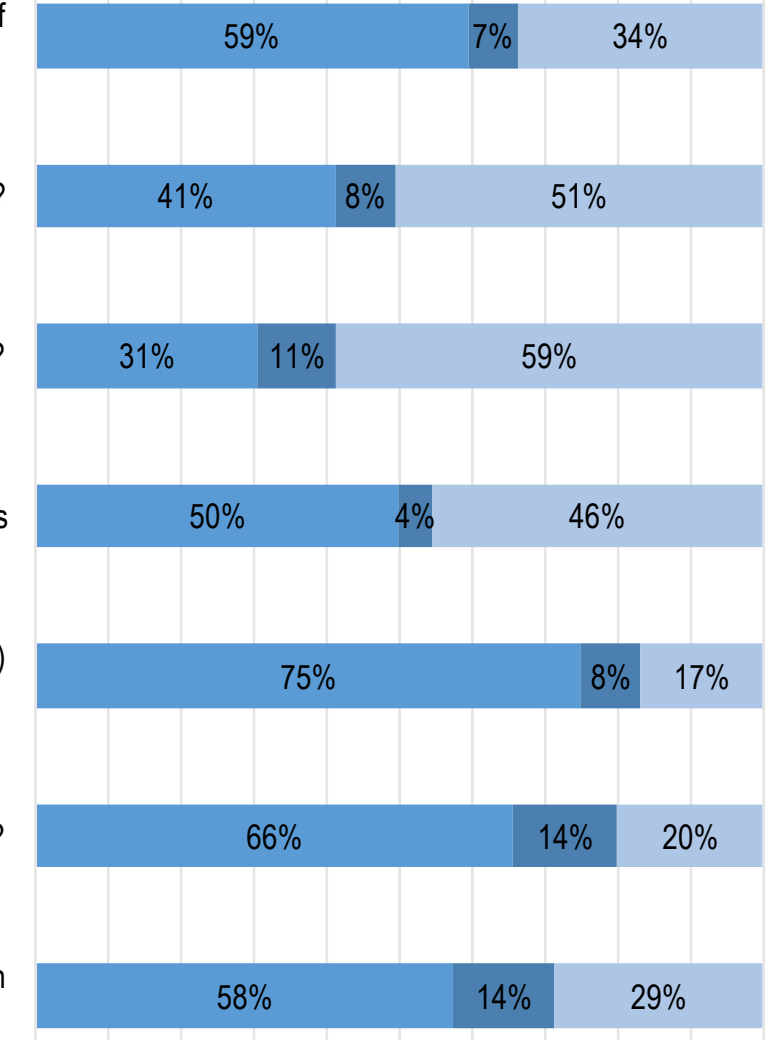

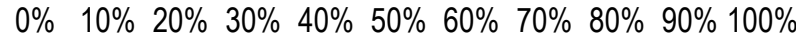

yes (independently) $\quad$ yes (with other agencies/bodies such as the government or other bodies) $\square$ no

Source: OECD 2018 Database on the Governance of Sector Regulators.

63. Ministerial regulators have a higher average scope of action score in all sectors, suggesting that independent regulators engage in more of the activities identified in this component than ministerial regulators (Table 8). It should be noted that regulators also carry out activities not included in the survey, often following ad-hoc requests from the 
executive which may include administering emergency funds and resolving disputes around concession contracts.

Table 8. Average scores, scope of action component, independent and ministerial regulators

\begin{tabular}{lcrrrr}
\hline & Energy & E-communications & Rail & Air & \multicolumn{1}{l}{ Water } \\
\hline Independent regulators & 1.31 & 0.91 & 2.07 & 2.62 & 2.03 \\
Ministerial regulators & 2.31 & 1.75 & 2.65 & 3.43 & 3.78 \\
\hline
\end{tabular}

Source: OECD 2018 Database on the Governance of Sector Regulators.

64. Most regulators (90\%) issue sanctions and penalties. In most cases, sanctions are levied independently by the regulator or through a court injunction $(83 \%$ of regulators who are empowered to issue sanctions or penalties); the remaining $17 \%$ of regulators, especially those in the energy and rail sectors, must cooperate with other agencies or government bodies to issue sanctions and penalties.

65. Almost all regulators can collect information from regulated entities through a compulsory process, and the majority have sanctioning power for non-compliance. Data collection powers do not necessarily translate into use of data, and several regulators appear to be taking steps towards better internal data management and analysis processes at the time of writing, including exploring the use of big data and artificial intelligence techniques.

66. Fifteen regulators have more than one sector (out of the five sectors covered in this survey) within their purview and can be classified as multi-sector regulators, representing around $12 \%$ of all regulators sampled. All of the multi-sector regulators with competences in the water sector have competences in the energy sector as well ${ }^{9}$, and all of those with competences in the air sector also have competences in the rail sector. Regulators in Australia, Estonia, Luxembourg and the Netherlands oversee four or more sectors. Some multi-sector regulators are also the national competition authority (e.g. Estonia, the Netherlands, Australia and Spain).

${ }^{9}$ This is consistent with previous survey findings, where in the majority of multi-sector regulators ( 20 out of 23), water is bundled with energy competencies. The report also found that, in 9 cases, the sectors in their portfolio have different business cycles, which allow the technical staff to work across sectors (OECD, 2015 [29]). 
Table 9. Regulators in charge of more than one sector

\begin{tabular}{|c|c|c|c|c|c|c|c|}
\hline & Regulator & Acronym & Energy & $\begin{array}{l}\text { E- } \\
\text { comms }\end{array}$ & Rail & Air & Water \\
\hline Australia & Australian Competition and Consumer Commission & ACCC & $x^{1}$ & $x$ & $\mathrm{x}$ & $\mathrm{x}$ & $\mathrm{x}$ \\
\hline Belgium & $\begin{array}{l}\text { Dienst Regulering van het Spoorwegvervoer en van de Exploitatie van } \\
\text { de Luchthaven Brussel-Nationaal (Regulatory Service for Railway } \\
\text { Transport and for Brussels Airport Operations) }\end{array}$ & & & & $x$ & $x$ & \\
\hline Estonia & Konkurentsiamet (Estonian Competition Authority) & & $\mathrm{x}$ & & $\mathrm{x}$ & $\mathrm{x}$ & $\mathrm{x}$ \\
\hline Germany & Bundesnetzagentur & BNetzA & $\mathrm{x}$ & $\mathrm{x}$ & $\mathrm{x}$ & & \\
\hline Ireland & Commission for Regulation of Utilities & CRU & $\mathrm{x}$ & & & & $\mathrm{x}$ \\
\hline Italy & Autorità di Regolazione dei Trasporti (Transport Regulation Authority) & ART & & & $x$ & $x^{2}$ & \\
\hline Italy & $\begin{array}{l}\text { Autorità di Regolazione per Energia Reti e Ambiente (Italian } \\
\text { Regulatory Authority for Energy Networks and Environment) }\end{array}$ & ARERA & $x$ & & & & $\mathrm{x}$ \\
\hline Latvia & $\begin{array}{l}\text { Sabiedrisko pakalpojumu regulešanas komisija (Public Utilities } \\
\text { Commission) }\end{array}$ & SPRK & $\mathrm{x}$ & $\mathrm{x}$ & & & $\mathrm{x}$ \\
\hline Lithuania & $\begin{array}{l}\text { Lietuvos Respublikos ryšiu reguliavimo tarnyba (Communications } \\
\text { Regulatory Authority of the Republic of Lithuania) }\end{array}$ & RRT & & $\mathrm{x}$ & $x$ & & \\
\hline Lithuania & $\begin{array}{l}\text { Valstybine kainu ir energetikos kontroles komisija (National } \\
\text { Commission for Energy Control and Prices of Lithuania) }\end{array}$ & VKEKK & $\mathrm{x}$ & & & & $x$ \\
\hline Luxembourg & $\begin{array}{l}\text { Institut Luxembourgeois de Régulation (Luxembourg Institute of } \\
\text { Regulation) }\end{array}$ & ILR & $\mathrm{x}$ & $\mathrm{x}$ & $\mathrm{x}$ & $\mathrm{x}$ & \\
\hline Netherlands & Autoriteit Consument en Markt (Authority for Consumers and Markets) & ACM & $\mathrm{x}$ & $x$ & $\mathrm{x}$ & $x$ & \\
\hline $\begin{array}{l}\text { Slovak } \\
\text { Republic }\end{array}$ & $\begin{array}{l}\text { Úrad pre reguláciu sietových odvetví (Regulatory Office for Network } \\
\text { Industries) }\end{array}$ & URSO & $\mathrm{x}$ & & & & $\mathrm{x}$ \\
\hline Spain & $\begin{array}{l}\text { Comisión Nacional de los Mercados y la Competencia (National } \\
\text { Authority for Markets and Competition) }\end{array}$ & CNMC & $\mathrm{x}$ & $\mathrm{x}$ & $\mathrm{x}$ & & \\
\hline Sweden & Transportstyrelsen (Swedish Transport Agency) & & & & $\mathrm{x}$ & $\mathrm{x}$ & \\
\hline
\end{tabular}

Notes:

1 The Australian Energy Regulator is Australia's national energy regulator. It has an independent board and shares staff, resources and facilities with the ACCC.

${ }^{2}$ Regulatory duties in the Italian air sector are shared between ART and the Civil Aviation Authority (ENAC).

Source: OECD 2018 Database on the Governance of Sector Regulators.

\section{Conclusions and ways forward}

\subsection{Conclusions}

67. The analysis of the 2018 Indicators on the Governance of Sector Regulators sheds light on a topic, the governance arrangements of sector regulators, typically overlooked by the economic literature. Through an objective and evidence-based approach that combines de jure and de facto attributes of regulatory agencies, the indicators show that governance structures vary considerably across countries and sectors.

68. Nonetheless, we can identify some trends. Regulators with greater independence (typically in the energy and e-communications sectors) also tend to have stronger accountability arrangements, such as reporting requirements and consultation practices. There seems to be room for improvement in those practices for air and rail transport regulators. Beyond legal status, practical arrangements determine de facto independence. For instance, the indicators show that post-employment restrictions for those in positions of leadership are widespread, but more energy regulators could adopt this practice as they are behind other sectors.

69. The highest convergence across countries and sectors is achieved with respect of independence arrangements, showing a degree of harmonisation. The convergence could 
reflect a number of factors: the legal requirements introduced by EU Directives in the energy, rail and telecom sectors, a growing consensus among policy-makers and regulators expressed in the Recommendation on Regulatory Policy and Governance and the work of the Network of Economic Regulators, and a renewed focus of national governments to develop institutions that accompany market-opening reforms.

70. At the institutional level, the 2018 indicators are useful to map some other overarching patterns in governance arrangements. It is clear that a majority of regulators in all sectors are agencies with some degree of independence from the executive; at the same time nearly half of the air sector regulators and one-quarter of rail and water regulators are ministerial agencies. Multi-sector regulators are a minority, but a clear pattern emerges with some regulators having both energy and water companies and others typically regulating air and rail transport.

\subsection{Limitations}

71. While the 2018 indicators represent a unique repository of comparable information on the governance of sector regulators, it is important to keep in mind some limitations when interpreting the results. First, contextual factors such as political, institutional and market conditions play a role in the development of governance arrangements. It is difficult to capture these factors in the quantitative indicators. Second, the nature of closed-ended questions is such that indicators may oversimplifying unusual or nuanced governance arrangements and may not fully capture the diversity of those arrangements.

72. The weighting method used to calculate the composite indicators also presents a limitation. The questionnaire uses equal weighting to avoid imposing judgements about the importance of the elements to the composite indicators. While this approach implies that all elements of the composite indicator have the same "worth", it does not mean that the elements lack weights entirely. An equal weighting approach has its drawbacks. Notably, an equal weighting methodology that groups elements into components before aggregating the components into the final composite can distort the weighting of the components itself. Additionally, equal weighting does not protect against "double-counting" when highly correlated variables are included in the composite. Despite these challenges, the composite indicator provides an indication of the relative degree to which a regulator's governance arrangements reflect good practice; delving into the underlying data provides a richer overview of the elements driving observed differences. Equal weighting and alternative methods for weighting elements of composite indicators are reviewed in the OECD Handbook on Constructing Composite Indicators (OECD, 2008 [14] $)$.

73. In future editions, the questionnaire can continue to evolve with additional questions to capture a more accurate or complete picture of regulators' independence, accountability and scope of action.

\subsection{Ways forward}

74. The 2018 indicators provide a comparative, quantitative tool for those regulators and countries wishing to assess their alignment with OECD good practice in the area of regulators' governance. The results offer the opportunity to check this alignment as of 2018, bearing in mind that governance arrangements will change and good practice principles will continue to evolve. Examples already exist of both national (Zemanovicova and Holienka, 2017 $[12]$ ) and international (Ottow, 2015 $5_{[15]}$; Koop and Hanretty, 2018 ${ }_{[16]}$ ) assessments of the optimal institutional arrangements of independent regulators. 
75. In addition, regulatory agencies and policy-makers can use the results as a diagnostic tool, in order to identify areas most in need of reform with respect to governance structures. The indicators can also serve as impact assessment tools, showing how the gap between current and good practices would narrow if certain reforms were enacted.

76. The OECD Secretariat will continue to rely on the indicators as part of its Regulatory Policy Reviews, Performance Assessment Framework for Economic Regulators (PAFER) (OECD, 2016 ${ }_{[17]}$; OECD, 2018 $\left.{ }_{[18]}\right)$ and Economic Surveys.

77. The indicators can also be the basis for in-depth analysis trying to understand the outcomes that different governance arrangements yield on regulatory performance. Other studies indicate the need to understand the extent to which "different economic and political variables that interact with agency dynamics contribute to improve their performance, or to the contrary, create gridlocks and other grievances" (Jordana, Fernández-i-Marín and Bianculli, 2018 ${ }_{[19]}$; OECD, 2017 [20]; OECD, 2017 [21]).

78. New research will need to assess the relationship between governance arrangements and the overall performance of a sector or industry (for example, as measured by investment, service quality, competition, or frequency of disputes between market actors), building on work such as Sutherland $\left(2011_{[22]}\right)$. This work could be particularly relevant for regulators aiming to assess their impacts on regulated markets and to show their added value in the national economy. In addition, research could explore the relationship between governance arrangements and perceived effectiveness of regulatory actions by customers and regulated entities, as more regulators aim to measure this through perception surveys. 


\section{References}

(n.a.) (2017), LOI $n^{\circ} 2017-55$ du 20 janvier 2017 portant statut général des autorités administratives indépendantes et des autorités publiques indépendantes, https://www.legifrance.gouv.fr/eli/loi/2017/1/20/PRMX1604064L/jo/texte.

Directive 2009/140/EC of the European Parliament and of the Council of 25 November 2009 (2009), , Official Journal of the European Union L 337, pp. 37- 69.

Directive 2009/72/EC of the European Parliament and of the Council of 13 July 2009 (2009), Official Journal of the European Union L 211, pp. 55-93.

Directive 2009/73/EC of the European Parliament and of the Council of 13 July 2009 (2009), , Official Journal of the European Union L 211, pp. 94 - 136.

Directive 2012/34/EU of the European Parliament and of the Council of 21 November 2012 (2012), , Official Journal of the European Union L 343, pp. 32-77.

Huber, J. and C. Shipan (2002), Deliberate Discretion? The institutional foundations of bureaucratic autonomy, Cambridge University Press, https://doi.org/10.1017/CBO9780511804915.

Jordana, J., X. Fernández-i-Marín and A. Bianculli (2018), “Agency proliferation and the globalization of the regulatory state: Introducing a data set on the institutional features of regulatory agencies", Regulation and Gobernance, Vol. 12/4, https://doi.org/10.1111/rego.12189.

Koop, C. and C. Hanretty (2018), "Political Independence, Accountability, and the Quality of Regulatory Decision-Making”, Comparative Political Studies, Vol. 51/1, pp. 38-75, http://dx.doi.org/10.1177/0010414017695329.

Koske, I. et al. (2016), "Regulatory management practices in OECD countries", OECD Economics Department Working Papers, No. 1296, OECD Publishing, Paris, https://dx.doi.org/10.1787/5jm0qwm7825h-en.

OECD (2018), Driving Performance at Ireland's Commission for Regulation of Utilities, The Governance of Regulators, OECD Publishing, Paris, https://dx.doi.org/10.1787/9789264190061-en.

OECD (2017), Creating a Culture of Independence: Practical Guidance against Undue Influence, The Governance of Regulators, OECD Publishing, Paris, https://dx.doi.org/10.1787/9789264274198-en.

OECD (2017), Driving Performance at Mexico's Energy Regulatory Commission, The Governance of Regulators, OECD Publishing, Paris, https://dx.doi.org/10.1787/9789264280830-en. 
OECD (2017), Driving Performance of Mexico's Energy Regulators, The Governance of

Regulators, OECD Publishing, Paris, https://dx.doi.org/10.1787/9789264267848-en.

OECD (2017), Updating the indicators on the governance of regulators in the Product Market Regulation dataset - Annex 2, ECO/CPE/WP1(2017)25/ANN2.

OECD (2017), What's next with the PMR? Updating sector regulation and regulators indicators of the Product Market Regulation dataset, GOV/RPC/NER/RD(2017)2.

OECD (2016), Being an Independent Regulator, The Governance of Regulators, OECD Publishing, Paris, https://dx.doi.org/10.1787/9789264255401-en.

OECD (2016), Driving Performance at Latvia's Public Utilities Commission, The Governance of Regulators, OECD Publishing, Paris, https://dx.doi.org/10.1787/9789264257962-en.

OECD (2016), Governance of Regulators' Practices: Accountability, Transparency and Coordination, The Governance of Regulators, OECD Publishing, Paris, https://dx.doi.org/10.1787/9789264255388-en.

OECD (2015), Driving Performance at Colombia's Communications Regulator, OECD Publishing, Paris, https://dx.doi.org/10.1787/9789264232945-en.

OECD (2015), The Governance of Water Regulators, OECD Studies on Water, OECD Publishing, Paris, https://dx.doi.org/10.1787/9789264231092-en.

OECD (2014), The Governance of Regulators, OECD Best Practice Principles for Regulatory Policy, OECD Publishing, Paris, https://dx.doi.org/10.1787/9789264209015-en.

OECD (2012), Recommendation of the Council on Regulatory Policy and Governance, OECD Publishing, Paris, https://dx.doi.org/10.1787/9789264209022-en.

OECD (2008), Handbook on Constructing Composite Indicators: Methodology and User Guide, https://www.oecd.org/sdd/42495745.pdf.

OECD (n.d.), Driving performance of regulators, http://www.oecd.org/gov/regulatorypolicy/driving-performance-of-regulators.htm.

OECD Council on Regulatory Policy and Governance (2012), Recommendation of the Council on Regulatory Policy and Governance, https://www.oecd.org/governance/regulatorypolicy/49990817.pdf.

Ottow, A. (2015), Market and Competition Authorities: Good Agency Principles, Oxford University Press.

Sutherland, D. et al. (2011), "Public Policies and Investment in Network Infrastructure", OECD Journal: Economic Studies, Vol. 2011/1, https://dx.doi.org/10.1787/eco_studies-2011$\underline{5 \mathrm{~kg} 51 \mathrm{mlvk6r6} .}$

Tucker, P. (2018), Unelected Power: The Quest for Legitimacy in Central Banking and the Regulatory State, Princeton University Press. 
Zemanovicova, D. and M. Holienka (2017), Independent Economic Regulation for Efficient and Fair Business: Case Study of Utilities Sector in Slovakia, Springer Proceedings in Business and Economics, pp. 273:280, https://www.springer.com/gp/book/9783319682846. 


\section{Annex A. Countries and regulators included in the 2018 Indicators on the Governance of Sector Regulators}

\begin{tabular}{|c|c|c|}
\hline Country & Sector & Regulator \\
\hline \multirow[t]{5}{*}{ Argentina } & Energy & $\begin{array}{l}\text { Ente Nacional Regulador de la Electricidad (National } \\
\text { Electricity Regulator, ENRE) } \\
\text { Ente Nacional Regulador del Gas (National Gas } \\
\text { Regulator, ENARGAS) }\end{array}$ \\
\hline & E-communications & $\begin{array}{lccc}\text { Ente Nacional de } & \text { Comunicaciones } & \text { (National } \\
\text { Communications Agency, ENACOM) } & \\
\end{array}$ \\
\hline & Rail transport & $\begin{array}{l}\text { Comisión Nacional de Regulación del Transporte } \\
\text { (National Commission for Transport Regulation, CNRT) }\end{array}$ \\
\hline & Air transport & $\begin{array}{l}\text { Organismo Regulador del Sistema Nacional de } \\
\text { Aeropuertos (National Airports System Regulatory } \\
\text { Body, ORSNA) }\end{array}$ \\
\hline & Water [Buenos Aires] & $\begin{array}{l}\text { Ente Regulador de Aguas y Saneamiento (Regulatory } \\
\text { Body for Water and Sanitation of Buenos Aires, ERAS) }\end{array}$ \\
\hline \multirow[t]{5}{*}{ Australia } & Energy & Australian Energy Regulator (AER) \\
\hline & E-communications & $\begin{array}{l}\text { Australian Competition and Consumer Commission } \\
\text { (ACCC) }\end{array}$ \\
\hline & Rail transport & $\begin{array}{l}\text { Australian Competition and Consumer Commission } \\
\text { (ACCC) }\end{array}$ \\
\hline & Air transport & $\begin{array}{l}\text { Australian Competition and Consumer Commission } \\
\text { (ACCC) }\end{array}$ \\
\hline & Water & $\begin{array}{l}\text { Australian Competition and Consumer Commission } \\
\text { (ACCC) }\end{array}$ \\
\hline \multirow[t]{4}{*}{ Austria } & Energy & E-control \\
\hline & E-communications & $\begin{array}{l}\text { The Austrian Regulatory Authority for Broadcasting and } \\
\text { Telecommunications (RTR-GmbH) }\end{array}$ \\
\hline & Rail transport & $\begin{array}{l}\begin{array}{l}\text { Schienen-Control Kommission } \\
\text { Commission) }\end{array} \\
\text { (Rail }\end{array}$ \\
\hline & Air transport & $\begin{array}{l}\text { Federal Ministry of Transport, Innovation and } \\
\text { Technology }\end{array}$ \\
\hline \multirow[t]{5}{*}{ Belgium } & Energy & $\begin{array}{l}\text { Commission de Régulation de l'Électricité et du Gaz } \\
\text { (Commission for Electricity and Gas Regulation, CREG) }\end{array}$ \\
\hline & E-communications & $\begin{array}{lllll}\text { Belgian Institute for } & \text { Postal } & \text { services } & \text { and } \\
\text { Telecommunications (BIPT) } & & & \\
\end{array}$ \\
\hline & Rail transport & $\begin{array}{l}\text { Regulatory Service for Railway Transport and for } \\
\text { Brussels Airport Operations }\end{array}$ \\
\hline & Air transport & $\begin{array}{l}\text { Regulatory Service for Railway Transport and for } \\
\text { Brussels Airport Operations }\end{array}$ \\
\hline & Water [Flanders] & Flanders Environment Agency (VMM) \\
\hline Brazil & Energy & $\begin{array}{l}\text { Agência Nacional de Energia Elétrica } \\
\text { Regulatory Agency, ANEEL) } \\
\text { Agência Nacional do Petróleo, Gás } \\
\text { Biocombustíveis (National Agency of Petral e } \\
\text { Natural Gas and Biofuels; ANP) }\end{array}$ \\
\hline
\end{tabular}




\begin{tabular}{|c|c|c|}
\hline & E-communications & $\begin{array}{l}\text { Agência Nacional de Telecomunicações (National } \\
\text { Telecommunications Agency, ANATEL) }\end{array}$ \\
\hline & Rail transport & $\begin{array}{l}\text { Agência Nacional de Transportes Terrestres (National } \\
\text { Ground Transportation Agency, ANTT) }\end{array}$ \\
\hline & Air transport & $\begin{array}{l}\text { Agência Nacional de Aviação Civil (National Civil } \\
\text { Aviation Agency, ANAC) }\end{array}$ \\
\hline & Water & $\begin{array}{l}\text { Agência Nacional de Águas (National Water Agency, } \\
\text { ANA) }\end{array}$ \\
\hline \multirow[t]{4}{*}{ Canada } & Energy [Ontario] & Ontario Energy Board \\
\hline & E-communications & $\begin{array}{l}\text { Canadian Radio-television and Telecommunications } \\
\text { Commission (CRTC) }\end{array}$ \\
\hline & Rail transport & Canadian Transport Agency \\
\hline & Air transport & Canadian Transport Agency \\
\hline \multirow[t]{5}{*}{ Chile } & Energy & $\begin{array}{l}\text { Comisión Nacional de Energía (National Energy } \\
\text { Commission, CNE) }\end{array}$ \\
\hline & E-communications & $\begin{array}{l}\text { Subsecretaria de Telecomunicaciones (Undersecretariat } \\
\text { of Telecommunications, SUBTEL) }\end{array}$ \\
\hline & Rail transport & $\begin{array}{l}\text { Ministerio de Transportes y Telecomunicaciones } \\
\text { (Ministry of Transport and Telecommunications) }\end{array}$ \\
\hline & Air transport & $\begin{array}{l}\text { Dirección General de Aeronáutica Civil (General } \\
\text { Directorate of Civil Aviation, DGAC) }\end{array}$ \\
\hline & Water & $\begin{array}{l}\text { Superintendencia de Servicios Sanitarios } \\
\text { (Superintendency of Sanitary Services, SISS) }\end{array}$ \\
\hline \multirow[t]{5}{*}{ Czech Republic } & Energy & $\begin{array}{l}\text { Energetický regulační úřad (Energy Regulatory Office, } \\
\text { ERU) }\end{array}$ \\
\hline & E-communications & $\begin{array}{lcll}\text { Český } & \text { telekomunikační } & \text { úrad } & \text { (Czech } \\
\text { Telecommunications Office) } & & \\
\end{array}$ \\
\hline & Rail transport & $\begin{array}{l}\text { Úřad pro př́stup k dopravní infrastructure (Infrastructure } \\
\text { Access Authority, UPDI) }\end{array}$ \\
\hline & Air transport & Ministry of Transportation \\
\hline & Water & $\begin{array}{l}\text { Coordinating Committee for the Regulation of Water and } \\
\text { Sewerage Systems }\end{array}$ \\
\hline \multirow[t]{5}{*}{ Denmark } & Energy & Energitilsynet (Danish Energy Regulatory Authority) \\
\hline & E-communications & Danish Business Authority \\
\hline & Rail transport & Danish Rail Regulatory Body \\
\hline & Air transport & Danish Transport, Construction, and Housing Authority \\
\hline & Water & Danish Water Utility Regulatory Authority \\
\hline \multirow[t]{4}{*}{ Estonia } & Energy & Estonian Competition Authority \\
\hline & Rail transport & Estonian Competition Authority \\
\hline & Air transport & Estonian Competition Authority \\
\hline & Water & Estonian Competition Authority \\
\hline \multirow[t]{3}{*}{ Finland } & Energy & Energy Authority \\
\hline & E-communications & $\begin{array}{lll}\text { Finnish Communications } & \text { Regulatory } & \text { Authority } \\
\text { (FICORA) } & & \\
\end{array}$ \\
\hline & Rail transport & Rail Regulatory Body \\
\hline France & Energy & $\begin{array}{llll}\text { Commission de régulation de l'énergie } & \text { (Energy } \\
\text { Regulatory Commission, CRE) } & & \\
\end{array}$ \\
\hline
\end{tabular}




\begin{tabular}{|c|c|c|}
\hline & E-communications & $\begin{array}{l}\text { Autorité de régulation des communications électroniques } \\
\text { et des postes (Electronic Communications and Postal } \\
\text { Regulatory Authority, Arcep) }\end{array}$ \\
\hline & Rail transport & $\begin{array}{l}\text { Autorité de régulation des activités ferroviaires et } \\
\text { routières (Regulatory Authority for Rail and Road } \\
\text { Activities. ARAFER) }\end{array}$ \\
\hline & Air transport & $\begin{array}{l}\text { Autorité de Supervision Indépendante des redevances } \\
\text { aéroportuaires (Independent Supervisory Authority for } \\
\text { Airport Charges, ASI) }\end{array}$ \\
\hline Germany & Energy & Bundesnetzagentur (Federal Network Agency, BNetzA) \\
\hline & E-communications & Bundesnetzagentur (Federal Network Agency, BNetzA) \\
\hline & Rail transport & Bundesnetzagentur (Federal Network Agency, BNetzA) \\
\hline Greece & Energy & Regulatory Authority for Energy \\
\hline & E-communications & Hellenic Telecommunications and Post Commission \\
\hline & Rail transport & Regulatory Authority for Railways (RAS) \\
\hline & Air transport & Civil Aviation Authority \\
\hline Hungary & Energy & $\begin{array}{l}\text { Magyar Energetikai és Közmü-szabályozási Hivatal } \\
\text { (Hungarian Energy and Public Utility Regulatory } \\
\text { Authority) }\end{array}$ \\
\hline & E-communications & $\begin{array}{l}\text { National Media and Infocommunications Authority } \\
\text { (NMHH) }\end{array}$ \\
\hline & Rail transport & Rail Regulatory Body \\
\hline & Air transport & Ministry for Development \\
\hline & Water & $\begin{array}{l}\text { Ministry of Interior (Department of River Basin } \\
\text { Management and Water Protection) }\end{array}$ \\
\hline Iceland & Energy & Orkustofnun, (National Energy Authority) \\
\hline & E-communications & Post and Telecom Administration (PFS) \\
\hline & Air transport & Icelandic Competition Authority (ICA) \\
\hline Ireland & Energy & $\begin{array}{l}\text { Commission for Regulation of Utilities Water and } \\
\text { Energy (CRU) }\end{array}$ \\
\hline & E-communications & Commission for Communications Regulation (ComReg) \\
\hline & Water & $\begin{array}{l}\text { Commission for Regulation of Utilities Water and } \\
\text { Energy (CRU) }\end{array}$ \\
\hline Israel & Energy & $\begin{array}{l}\text { Ministry of National Infrastructures, Energy and Water } \\
\text { Resources }\end{array}$ \\
\hline & E-communications & Ministry of Communications \\
\hline & Rail transport & $\begin{array}{l}\text { Ministry of Transport and Road Safety, National Public } \\
\text { Transport Authority }\end{array}$ \\
\hline & Air transport & Civil Aviation Authority \\
\hline & Water & The Governmental Authority for Water and Sewage \\
\hline Italy & Energy & $\begin{array}{l}\text { Italian Regulatory Authority for Energy Networks and } \\
\text { Environment (ARERA) }\end{array}$ \\
\hline & E-communications & $\begin{array}{l}\text { Autorità per le Garanzie nelle Comunicazioni } \\
\text { (Communications Regulatory Authority, AGCOM) }\end{array}$ \\
\hline & Rail transport & $\begin{array}{l}\text { Autorità di regolazione dei trasporti (Transport } \\
\text { Regulation Authority, ART) }\end{array}$ \\
\hline & Air transport & $\begin{array}{llll}\text { Autorità di regolazione dei } & \text { trasporti } & \text { (Transport } \\
\text { Regulation Authority, ART) } & & & \end{array}$ \\
\hline
\end{tabular}




\begin{tabular}{|c|c|c|}
\hline & Water & $\begin{array}{l}\text { Italian Regulatory Authority for Energy Networks and } \\
\text { Environment (ARERA) }\end{array}$ \\
\hline \multirow[t]{4}{*}{ Japan } & Energy & Ministry of Economy, Trade and Industry \\
\hline & E-communications & Ministry of Internal Affairs and Communications \\
\hline & Rail transport & $\begin{array}{l}\text { Ministry of Land, Infrastructure, Transport and Tourism } \\
\text { (Railway Bureau) }\end{array}$ \\
\hline & Air transport & Ministry of Land, Infrastructure, Transport and Tourism \\
\hline \multirow[t]{3}{*}{ Korea } & Energy & Korea Electricity Regulatory Commission (KOREC) \\
\hline & E-communications & Korea Communications Commission (KCC) \\
\hline & Water & Ministry of Environment \\
\hline \multirow[t]{5}{*}{ Latvia } & Energy & Public Utilities Commission \\
\hline & E-communications & Public Utilities Commission \\
\hline & Rail transport & State Railway Administration \\
\hline & Air transport & Civil Aviation Authority \\
\hline & Water & Public Utilities Commission \\
\hline \multirow[t]{5}{*}{ Lithuania } & Energy & $\begin{array}{l}\text { National Commission for Energy Control and Prices of } \\
\text { the Republic of Lithuania (NCC) }\end{array}$ \\
\hline & E-communications & $\begin{array}{l}\text { Communications Regulatory Authority of the Republic } \\
\text { of Lithuania (RRT) }\end{array}$ \\
\hline & Rail transport & $\begin{array}{l}\text { Communications Regulatory Authority of the Republic } \\
\text { of Lithuania (RRT) }\end{array}$ \\
\hline & Air transport & Civil Aviation Administration \\
\hline & Water & $\begin{array}{l}\text { National Commission for Energy Control and Prices of } \\
\text { the Republic of Lithuania (NCC) }\end{array}$ \\
\hline \multirow[t]{4}{*}{ Luxembourg } & Energy & $\begin{array}{l}\text { Institut Luxembourgeois de Régulation (Luxembourg } \\
\text { Regulatory Institute, ILR) }\end{array}$ \\
\hline & E-communications & $\begin{array}{l}\text { Institut Luxembourgeois de Régulation (Luxembourg } \\
\text { Regulatory Institute, ILR) }\end{array}$ \\
\hline & Rail transport & $\begin{array}{l}\text { Institut Luxembourgeois de Régulation (Luxembourg } \\
\text { Regulatory Institute, ILR) }\end{array}$ \\
\hline & Air transport & $\begin{array}{l}\text { Institut Luxembourgeois de Régulation (Luxembourg } \\
\text { Regulatory Institute, ILR) }\end{array}$ \\
\hline \multirow[t]{4}{*}{ Mexico } & Energy & $\begin{array}{l}\text { Comisión Reguladora de Energía (Energy Regulatory } \\
\text { Commission, CRE) }\end{array}$ \\
\hline & E-communications & $\begin{array}{l}\text { Instituto Federal de Telecomunicaciones (Federal } \\
\text { Telecommunications Institute, IFT) }\end{array}$ \\
\hline & Rail transport & $\begin{array}{llcl}\text { Agencia Reguladora del Transporte } & \text { Ferroviario } \\
\text { (Regulatory Agency for Rail Transport) } & \\
\end{array}$ \\
\hline & Air transport & $\begin{array}{l}\text { Dirección General de Aeronáutica Civil (Directorate } \\
\text { General of Civil Aeronautics, DGAC) }\end{array}$ \\
\hline \multirow[t]{5}{*}{ Netherlands } & Energy & Authority for Consumers and Markets (ACM) \\
\hline & E-communications & Authority for Consumers and Markets (ACM) \\
\hline & Rail transport & Authority for Consumers and Markets (ACM) \\
\hline & Air transport & Authority for Consumers and Markets (ACM) \\
\hline & Water & Ministry of Infrastructure and Water Management \\
\hline \multirow[t]{4}{*}{ New Zealand } & Energy & Electricity Authority \\
\hline & E-communications & Commerce Commission \\
\hline & Rail transport & New Zealand Transport Agency (NZTA) \\
\hline & Air transport & New Zealand Ministry of Transport \\
\hline
\end{tabular}




\begin{tabular}{|c|c|c|}
\hline \multirow[t]{4}{*}{ Norway } & Energy & $\begin{array}{l}\text { Norges vassdrags- og energidirektorat (Norwegian } \\
\text { Water Resources and Energy Directorate, NVE) }\end{array}$ \\
\hline & E-communications & Norwegian Communincation Authority (NKOM) \\
\hline & Rail transport & $\begin{array}{l}\text { Statens jernbanetilsyn (The Norwegian Railway } \\
\text { Authority) }\end{array}$ \\
\hline & Air transport & Luftfartstilsynet (Civil Aviation Authority) \\
\hline \multirow[t]{4}{*}{ Poland } & Energy & Energy Regulatory Office (ERO) \\
\hline & E-communications & Office of Electronic Communications (UKE) \\
\hline & Rail transport & Office of Rail Transport (UTK) \\
\hline & Air transport & Civil Aviation Authority (ULC) \\
\hline \multirow[t]{5}{*}{ Portugal } & Energy & $\begin{array}{l}\text { Entidade Reguladora dos Serviços Energéticos (Energy } \\
\text { Services Regulatory Authority, ERSE) }\end{array}$ \\
\hline & E-communications & $\begin{array}{l}\text { Autoridade Nacional das Comunicações (National } \\
\text { Communications Authority, ANACOM) }\end{array}$ \\
\hline & Rail transport & $\begin{array}{l}\text { Autoridade da Mobilidade e dos Transportes (Mobility } \\
\text { and Transport Authority) }\end{array}$ \\
\hline & Air transport & Portuguese Civil Aviation Authority (ANAC) \\
\hline & Water & $\begin{array}{l}\text { Entidade Reguladora dos Serviços de Águas e Resíduos } \\
\text { (Water and Waste Services Regulation Authority, } \\
\text { ERSAR) }\end{array}$ \\
\hline \multirow[t]{4}{*}{ South Africa } & Energy & National Energy Regulator of South Africa (NERSA) \\
\hline & E-communications & $\begin{array}{l}\text { Independent Communications Authority of South Africa } \\
\text { (ICASA) }\end{array}$ \\
\hline & Air transport & Regulating Committee \\
\hline & Water & Department of Water and Sanitation \\
\hline \multirow[t]{4}{*}{ Slovak Republic } & Energy & Regulatory Office for Network Industries (URSO) \\
\hline & E-communications & $\begin{array}{lccc}\text { Slovak Regulatory Authority for } & \text { Electronic } \\
\text { Communications and Postal Services } & & \\
\end{array}$ \\
\hline & Rail transport & Dopravný úrad (Transport Authority) \\
\hline & Water & Regulatory Office for Network Industries (URSO) \\
\hline \multirow[t]{2}{*}{ Slovenia } & Energy & Agencija za energijo (Energy Agency) \\
\hline & E-communications & $\begin{array}{l}\text { Agency for Communication Networks and Services of } \\
\text { the Republic of Slovenia }\end{array}$ \\
\hline \multirow[t]{4}{*}{ Spain } & Energy & $\begin{array}{l}\text { Comisión Nacional de los Mercados y la Competencia } \\
\text { (National Commission on Markets and Competition, } \\
\text { CNMC) }\end{array}$ \\
\hline & E-communications & $\begin{array}{l}\text { Comisión Nacional de los Mercados y la Competencia } \\
\text { (National Commission on Markets and Competition, } \\
\text { CNMC) }\end{array}$ \\
\hline & Rail transport & $\begin{array}{l}\text { Comisión Nacional de los Mercados y la Competencia } \\
\text { (National Commission on Markets and Competition, } \\
\text { CNMC) }\end{array}$ \\
\hline & Air transport & Ministry of Development (Ministerio de Fomento) \\
\hline \multirow[t]{4}{*}{ Sweden } & Energy & Swedish Energy Markets Inspectorate (Ei) \\
\hline & E-communications & Swedish Post and Telecom Authority (PTS) \\
\hline & Rail transport & Transportstyrelsen (Transport Agency) \\
\hline & Air transport & Transportstyrelsen (Transport Agency) \\
\hline
\end{tabular}




\begin{tabular}{|l|l|l|}
\hline Switzerland & Energy & $\begin{array}{l}\text { Commission fédérale de l'électricité (Federal Electricity } \\
\text { Commission, ElCom) }\end{array}$ \\
\cline { 2 - 3 } & E-communications & $\begin{array}{l}\text { Commission fédérale de la communication (Federal } \\
\text { Communications Commission, ComCom) }\end{array}$ \\
\cline { 2 - 3 } & Rail transport & Railways Arbitration Commission (RACO) \\
\cline { 2 - 3 } Turkey & Air transport & Federal Office of Civil Aviation Switzerland (FOCA) \\
\cline { 2 - 3 } & Energy & $\begin{array}{l}\text { Enerji Piyasas1 Düzenleme Kurumu (Energy Market } \\
\text { Regulatory Authority, EPDK) }\end{array}$ \\
\cline { 2 - 3 } & E-communications & $\begin{array}{l}\text { Bilgi Teknolojileri ve İletişim Kurumu (Information and } \\
\text { Communication Technologies Authority, BTK) }\end{array}$ \\
\cline { 2 - 3 } & Rail transport & $\begin{array}{l}\text { Demiryolu Düzenleme Genel Müdürlüğü (Directorate- } \\
\text { General of Railway Regulation, DDGM) }\end{array}$ \\
\cline { 2 - 3 } & Air transport & $\begin{array}{l}\text { Sivil Havacilik Genel Müdürlüğü (Directorate General of } \\
\text { Civil Aviation, SHGM) }\end{array}$ \\
\hline & Enited Kingdom & Office of Gas and Electricity Markets (Ofgem) \\
\cline { 2 - 3 } & E-communications & Office of Communications (Ofcom) \\
\cline { 2 - 3 } & Rail transport & Office of Rail and Road (ORR) \\
\cline { 2 - 3 } & Air transport & Civil Aviation Authority \\
\cline { 2 - 3 } & Water [Scotland] & Water Industry Commission for Scotland (WICS) \\
\hline
\end{tabular}




\section{Annex B. Schemata}

Table 1A: Scoring of questions in the independence section, relationship with the executive subsection

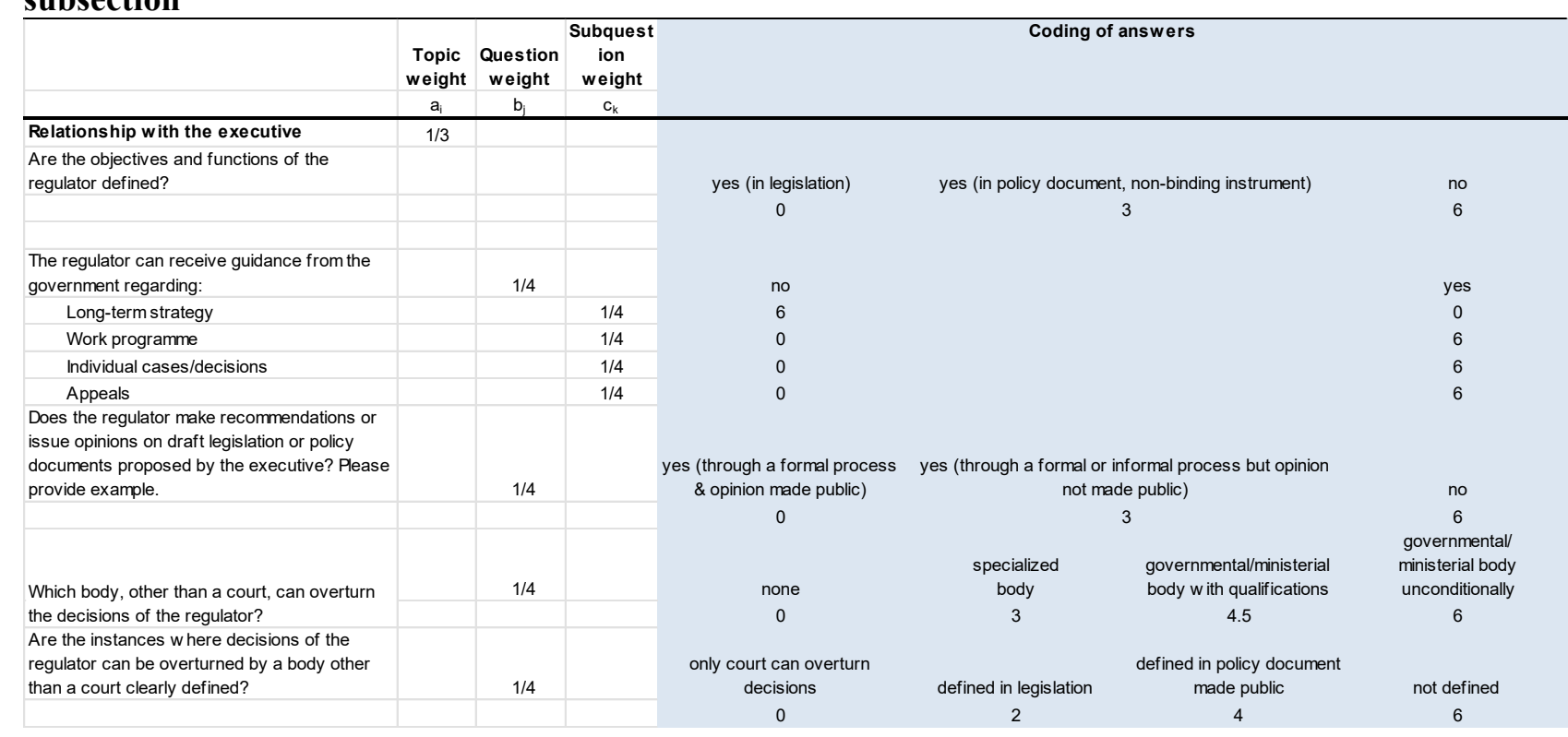


Table 1B: Scoring of questions in the independence section, staff subsection

\begin{tabular}{|c|c|c|c|c|c|c|c|}
\hline & $\begin{array}{l}\text { Topic } \\
\text { weight }\end{array}$ & $\begin{array}{c}\text { Question } \\
\text { weight }\end{array}$ & $\begin{array}{l}\text { Subquest } \\
\text { ion } \\
\text { weight }\end{array}$ & & Coding of ar & inswers & \\
\hline & $a_{i}$ & $b_{j}$ & $c_{k}$ & & & & \\
\hline Staff & $1 / 3$ & & & & & & \\
\hline \multirow[t]{2}{*}{ How is the majority of the staff recruited? } & & $1 / 12$ & & $\begin{array}{l}\text { positions are advertised } \\
\text { publicly } \& \text { candidates } \\
\text { examined by selection panel }\end{array}$ & direct call/appointment with & thout advertising positions & $\begin{array}{l}\text { secondment from private } \\
\text { sector and/or from } \\
\text { government bodies }\end{array}$ \\
\hline & & & & 0 & 3 & & 6 \\
\hline \multirow[t]{2}{*}{$\begin{array}{l}\text { What is the process for selecting the agency } \\
\text { head/board members? }\end{array}$} & & $1 / 12$ & & $\begin{array}{l}\text { position is publicly advertised } \\
\& \text { candidates examined by } \\
\text { independent selection panel }\end{array}$ & $\begin{array}{l}\text { ministerial/governmental non } \\
\text { ads \& independen }\end{array}$ & $\begin{array}{l}\text { mination based on public job } \\
\text { nt selection panel }\end{array}$ & $\begin{array}{c}\text { ministerial/governmental } \\
\text { nomination without } \\
\text { independent selection } \\
\text { panel }\end{array}$ \\
\hline & & & & 0 & 3 & & 6 \\
\hline \multirow[t]{2}{*}{$\begin{array}{l}\text { Which body has the legal authority to make the } \\
\text { final appointment of the agency head/board } \\
\text { members? }\end{array}$} & & $1 / 12$ & & $\begin{array}{l}\text { parliament/congress/parliamen } \\
\text { tary/congressional committee }\end{array}$ & $\begin{array}{l}\text { government/ministerial body } \\
\text { with binding opinion of } \\
\text { parliament/congress/parliam } \\
\text { entary/congressional } \\
\text { committee }\end{array}$ & $\begin{array}{c}\text { tw o or more } \\
\text { governmental/ministerial } \\
\text { bodies }\end{array}$ & $\begin{array}{l}\text { one government/ministerial } \\
\text { body }\end{array}$ \\
\hline & & & & 0 & 2 & 4 & 6 \\
\hline \multirow{2}{*}{$\begin{array}{l}\text { Are there restrictions regarding the } \\
\text { employment history of the agency head/board }\end{array}$} & & $1 / 12$ & & yes & & & no \\
\hline & & & & 0 & & & 6 \\
\hline \multirow[t]{2}{*}{$\begin{array}{l}\text { Does the legislation define the skills required by } \\
\text { the agency head/board members? }\end{array}$} & & $1 / 12$ & & yes & & & no \\
\hline & & & & 0 & & & 6 \\
\hline \multirow{2}{*}{$\begin{array}{l}\text { May the agency head/board members hold } \\
\text { other offices/appointments in the } \\
\text { government/the regulated industry? }\end{array}$} & & $1 / 12$ & & no & $\begin{array}{l}\text { yes ( } w \text { ith the consent of } \\
\text { the board) }\end{array}$ & $\begin{array}{l}\text { yes ( } w \text { ith restrictions, for } \\
\text { regulators with a agency } \\
\text { head) }\end{array}$ & yes ( $w$ ithout restrictions) \\
\hline & & & & 0 & 3 & 3 & 6 \\
\hline \multirow{2}{*}{$\begin{array}{l}\text { If the regulator is led by a board, are } \\
\text { appointments of board members staggered? }\end{array}$} & & $1 / 12$ & & yes & no & & $\mathrm{n} / \mathrm{a}^{1}$ \\
\hline & & & & 0 & 6 & & 0 \\
\hline \multirow{2}{*}{$\begin{array}{l}\text { How can the agency head/board members be } \\
\text { dismissed from office? }\end{array}$} & & $1 / 12$ & & through court procedure & through parliamentary/cc & ongressional decisions & $\begin{array}{l}\text { through government } \\
\text { decisions }\end{array}$ \\
\hline & & & & 0 & 3 & & 6 \\
\hline \multirow{2}{*}{$\begin{array}{l}\text { What are the criteria for dismissing agency } \\
\text { head/board members during their term of } \\
\text { office? }\end{array}$} & & $1 / 12$ & & $\begin{array}{l}\text { limited and defined set of } \\
\text { criteria }\end{array}$ & & & no defined set of criteria \\
\hline & & & & 0 & & & 6 \\
\hline \multirow[t]{2}{*}{$\begin{array}{l}\text { Are the criteria for dismissing agency } \\
\text { head/board members during their term of office } \\
\text { published? }\end{array}$} & & $1 / 12$ & & yes & nc & & $n / a^{2}$ \\
\hline & & & & 0 & 6 & & 6 \\
\hline \multirow[t]{2}{*}{$\begin{array}{l}\text { Can the agency head/board members accept } \\
\text { jobs in the government related to the sector } \\
\text { that is regulated by the regulator and/or the } \\
\text { sector that is regulated by the regulator after } \\
\text { their term of office? }\end{array}$} & & $1 / 12$ & & yes (after cooling off period) & $\begin{array}{l}\text { yes (provided that conflict } \\
\text { of interests rules are } \\
\text { complied with and/or } \\
\text { follow ing restrictions before } \\
\text { leaving) }\end{array}$ & no & yes ( $w$ ithout restrictions) \\
\hline & & & & 0 & 2 & 4 & 6 \\
\hline \multirow[t]{2}{*}{$\begin{array}{l}\text { How long is the term of office of the agency } \\
\text { head/board members? }\end{array}$} & & $1 / 12$ & & $\begin{array}{c}5 \text { years or more renew able } \\
\text { for a set number of terms or } \\
\text { non-renew able }\end{array}$ & $\begin{array}{l}\text { less than } 5 \text { years } \\
\text { renew able for a set number } \\
\text { of terms or non-renew able }\end{array}$ & $\begin{array}{l}5 \text { years or more and } \\
\text { renew able without } \\
\text { restrictions }\end{array}$ & $\begin{array}{l}\text { less than } 5 \text { years and } \\
\text { renew able without } \\
\text { restrictions or life } \\
\text { appointment }\end{array}$ \\
\hline & & & & 0 & 2 & 4 & 6 \\
\hline
\end{tabular}

Notes:

The answer options for the question "[w]hat is the process for selecting the agency head/board members?" do not describe the process of leadership selection for several regulators. First, they do not describe cases where a position is publicly advertised, but an independent selection panel is not involved, a process adopted by the Flemish water regulator (a sub-entity of the Flanders Environment Agency) and the Austrian energy regulator (E-Control). In these cases, reviewers suggested the respondent answer "ministerial/governmental nomination without independent selection panel." Second, they do not describe cases where the head is appointed by the president with the approval of the legislature, such as the Chilean Ministry of Transport and Telecommunications and the Swedish Energy Markets Inspectorate. As a best-fit answer for this version of the questionnaire, reviewers selected "ministerial/governmental nomination without independent selection panel." Finally, they do not describe the selection of the Danish Rail Regulatory Body chair, who is appointed by a presiding judge. Reviewers answered for the rest of the board members, who were appointed by a minister.

Two regulators were led jointly by two authorities: the Israeli water regulator (the Governmental Authority for Water and Sewage) and the Slovakian energy regulator (the Regulatory Office for Network Industries). The Governmental Authority for Water and Sewage has both a director and a council with distinct, complementary functions. Similarly, the Regulatory Office for Network Industries is led by a President and a Board. Because the questions about regulator leadership must be answered for an individual head or a board, the reviewers requested that the questions about leadership were answered for the director and president in order to distinguish between the two authorities. 
Table 1C: Scoring of questions in the independence section, budget subsection

\begin{tabular}{|c|c|c|c|c|c|c|c|c|}
\hline & & & Subquest & & Coding of a & answers & & \\
\hline & $a_{i}$ & $b_{j}$ & $\mathrm{c}_{\mathrm{k}}$ & & & & & \\
\hline Budget & $1 / 3$ & & & & & & & \\
\hline Is the source of the financial budget of the & & & & yes & & & no & \\
\hline & & $1 / 6$ & & 0 & & & 6 & \\
\hline What is the length of budget appropriations? & & & & at least three years & two years & annual & & \\
\hline & & $1 / 6$ & & 0 & 3 & 6 & & \\
\hline $\begin{array}{l}\text { If the regulator is financed in total or in part } \\
\text { through fees paid by the regulated sector, who } \\
\text { sets the level of the fees? }\end{array}$ & & & & $\begin{array}{l}\text { regulator within criteria set in } \\
\text { legislation }\end{array}$ & $\begin{array}{c}\text { parliament/congress/commit } \\
\text { tee upon proposal of the } \\
\text { regulator }\end{array}$ & $\begin{array}{l}\text { governmental/ministerial } \\
\text { body upon proposal of the } \\
\text { regulator }\end{array}$ & $\begin{array}{l}\text { governmental/ministerial } \\
\text { body }\end{array}$ & $n / a^{4}$ \\
\hline & & $1 / 6$ & & 0 & 2 & 4 & 6 & 0 \\
\hline $\begin{array}{l}\text { If the regulator is financed in total or in part } \\
\text { through the national budget, who is } \\
\text { responsible for proposing and discussing the } \\
\text { regulator's budget? }\end{array}$ & & & & $\begin{array}{l}\text { the regulator with no or limited } \\
\text { interventions from other } \\
\text { governmental/ministerial } \\
\text { bodies }\end{array}$ & $\begin{array}{l}\text { the regulator and another } \\
\text { governmental/ministerial } \\
\text { body }\end{array}$ & $\begin{array}{l}\text { a governmental body other } \\
\text { than the regulator }\end{array}$ & $n / a^{3}$ & \\
\hline & & $1 / 6$ & & 0 & 3 & 6 & 0 & \\
\hline $\begin{array}{l}\text { Does the regulator provide information to the } \\
\text { legislature or the relevant budget authority on } \\
\text { the costs and resources needed to fulfil its }\end{array}$ & & & & yes & & ר० & & \\
\hline mandate prior to the next budget cycle? & & $1 / 6$ & & 0 & & 6 & & \\
\hline $\begin{array}{l}\text { Which body is responsible for deciding the } \\
\text { regulator's allocation of expenditures? }\end{array}$ & & & & $\begin{array}{l}\text { regulator w ithin general } \\
\text { financial management rules }\end{array}$ & & & $\begin{array}{l}\text { governmental/ministerial } \\
\text { body }\end{array}$ & \\
\hline & & $1 / 6$ & & 0 & & & 6 & \\
\hline
\end{tabular}

\section{Notes:}

For the question "[w]hich body is responsible for deciding the regulator's allocation of expenditures," the answer for Denmark air does not perfectly fit into any of the drop-down menu categories. The regulator indicated that the body that determines the regulator's expenditures is Danish Parliament through the Finance Act. As a best-fit answer for this version of the questionnaire, the reviewers suggested the respondent answer "governmental/ministerial body" to reflect the role of the Ministry. 
Table 2: Scoring of questions in accountability section

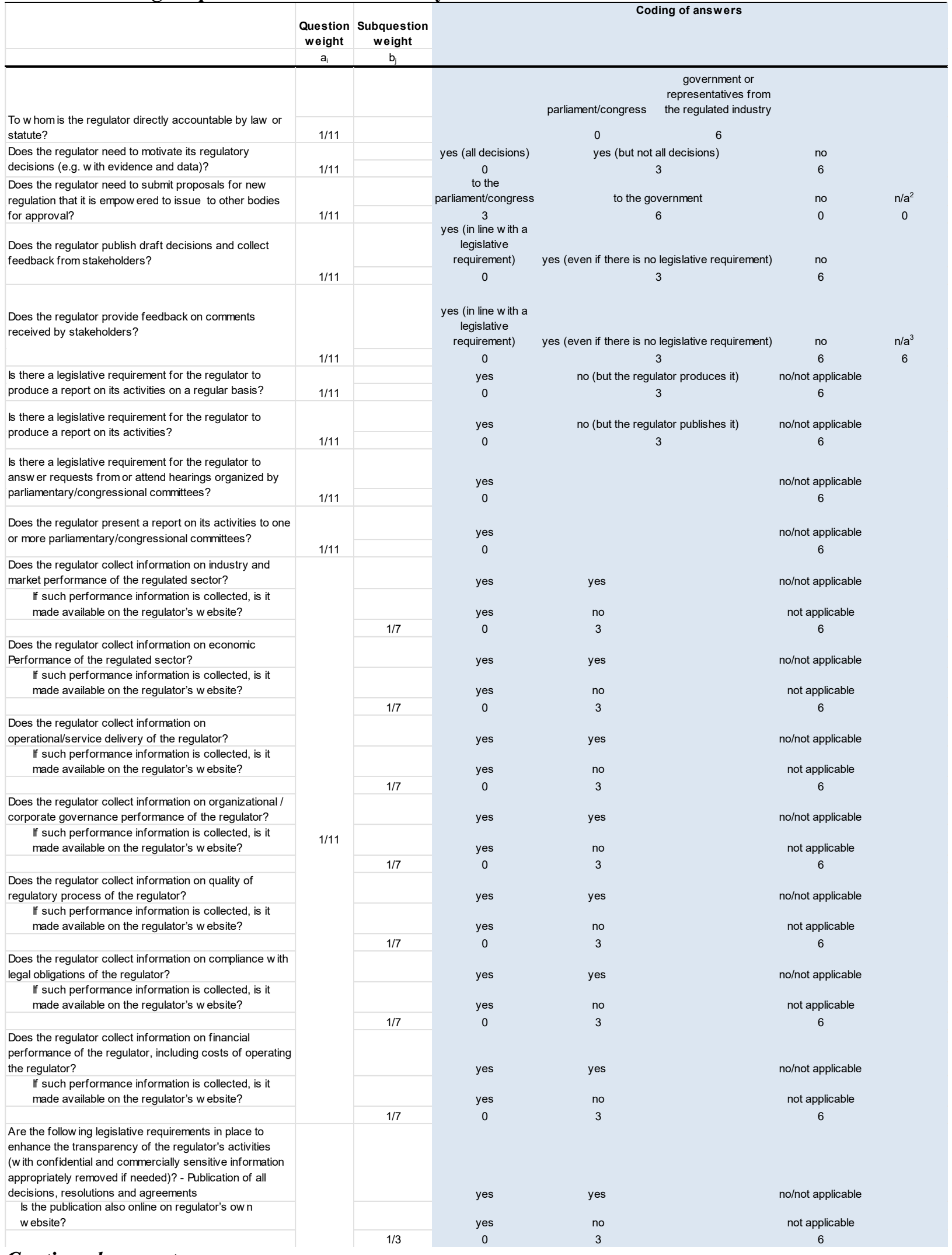

\section{Continued on next page}




\begin{abstract}
Are the follow ing legislative requirements in place to enhance the transparency of the regulator's activities

( $w$ ith confidential and commercially sensitive information

appropriately removed if needed)? - Public consultation on relevant activities

Is the publication also online on regulator's ow $n$

website?

Are the follow ing legislative requirements in place to

enhance the transparency of the regulator's activities

( $w$ ith confidential and commercially sensitive information

appropriately removed if needed)? - Publication of a

forw ard-looking action plan

is the publication also online on regulator's ow $n$ website?
\end{abstract}

$1 / 11$

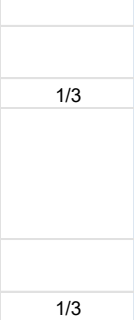

yes

yes

yes

yes
0 yes

yes

3 no/not applicable

not applicable

6

no/not applicable

not applicable 
Table 3: Scoring of questions in the scope of action section

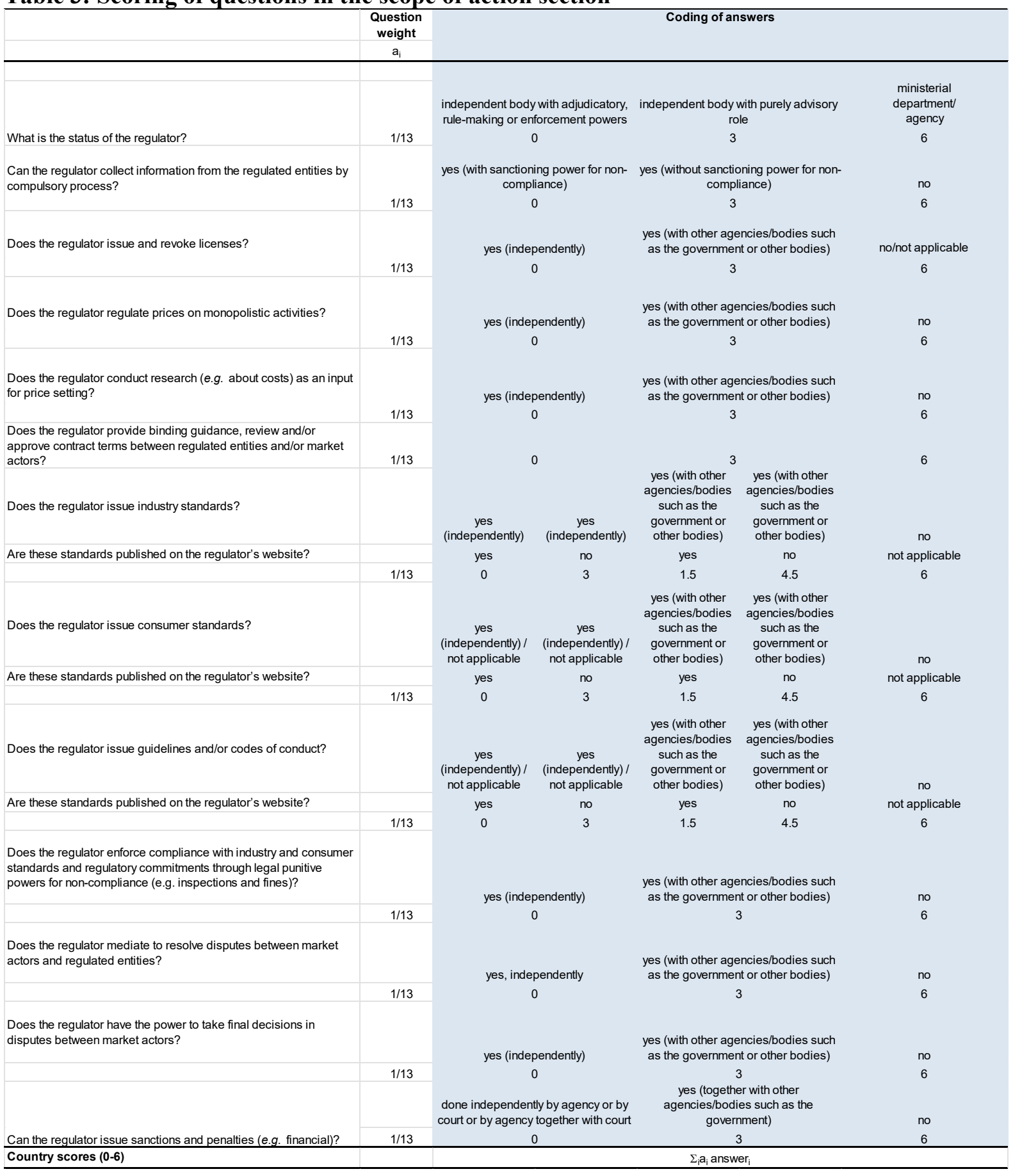




\section{Annex C. Aggregate scores, 2013 and 2018}

Figure A. 2013 Indicators
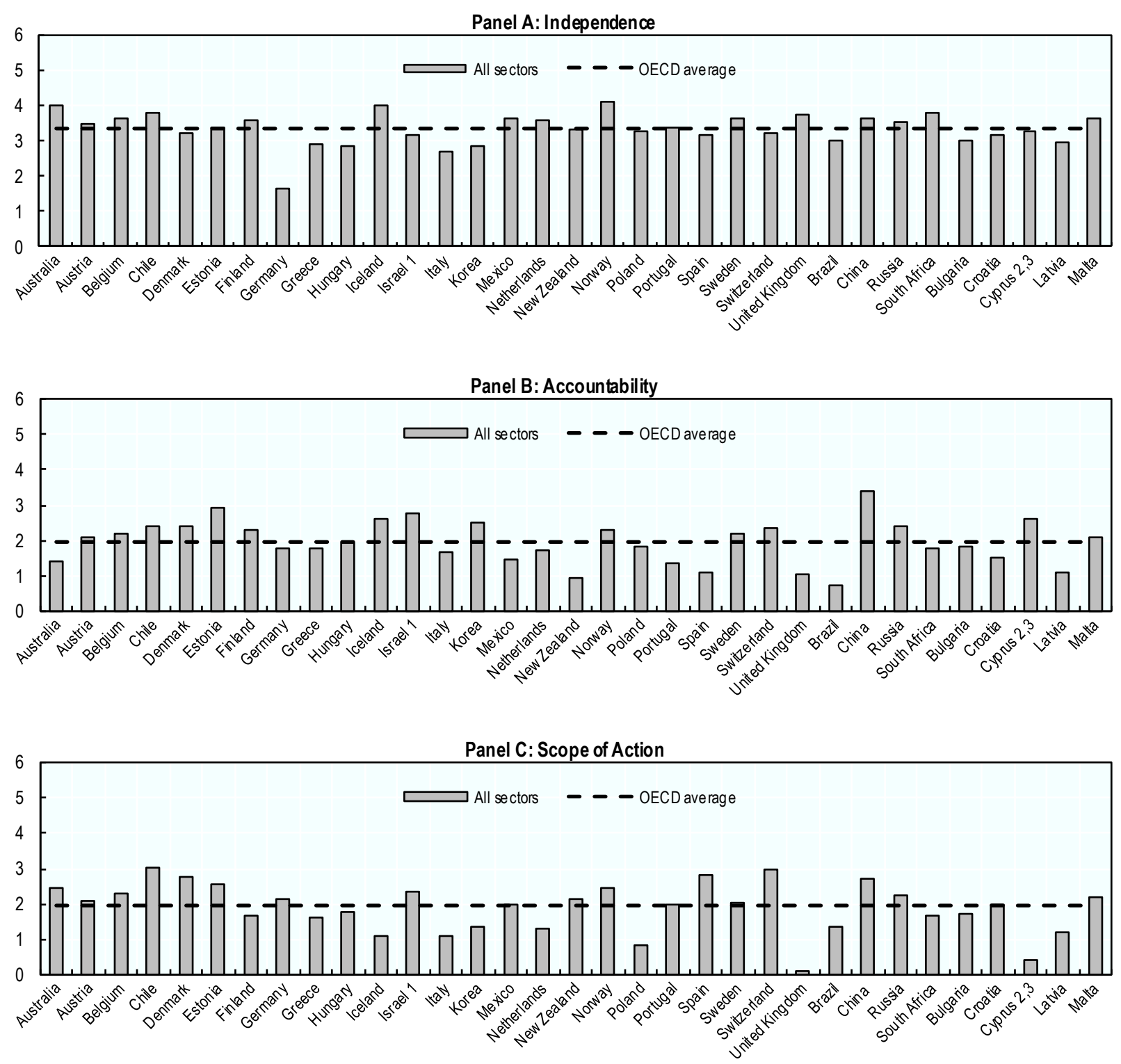

Notes:

1. The statistical data for Israel are supplied by and under the responsibility of the relevant Israeli authorities. The use of such data by the OECD is without prejudice to the status of the Golan Heights, East Jerusalem and Israeli settlements in the West

Bank under the terms of international law.

2. Note by Turkey: The information in this document with reference to "Cyprus" relates to the southern part of the Island.

There is no single authority representing both Turkish and Greek Cypriot people on the Island. Turkey recognises the Turkish Republic of Northern Cyprus (TRNC). Until a lasting and equitable solution is found within the context of the United Nations, Turkey shall preserve its position concerning the "Cyprus issue".

3. Note by all the European Union Member States of the OECD and the European Union: The Republic of Cyprus is recognised by all members of the United Nations with the exception of Turkey. The information in this document relates to the area under the effective control of the Government of the Republic of Cyprus.

Source: OECD 2018 Database on the Governance of Sector Regulators. 
Figure B. 2018 Indicators

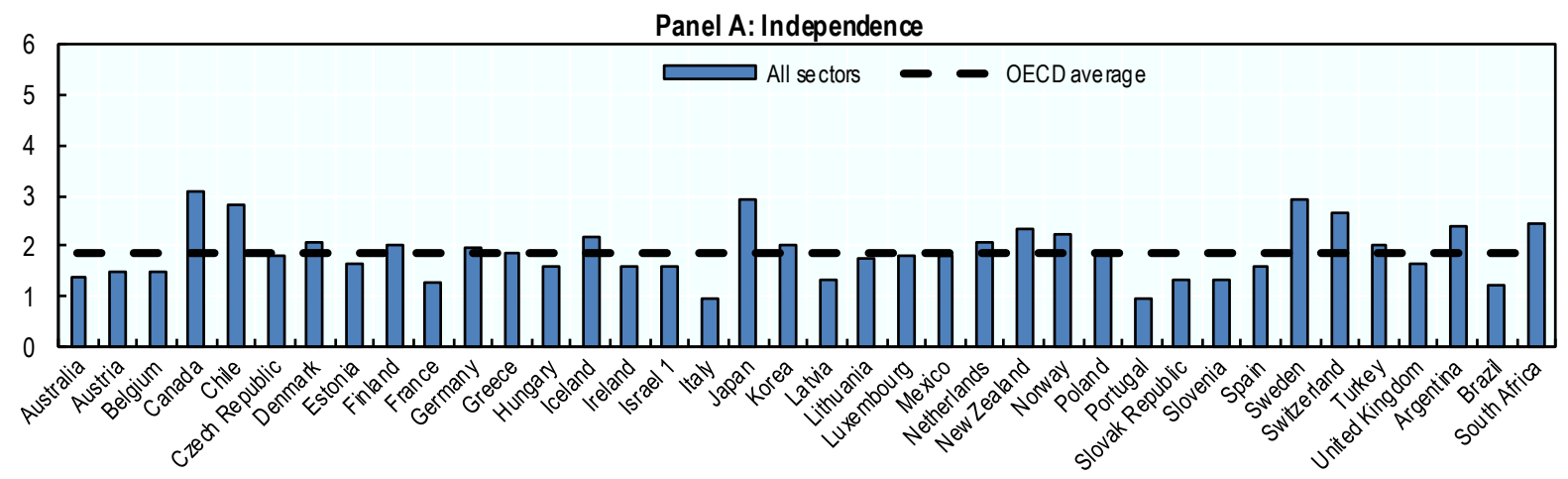

Panel B: Accountability

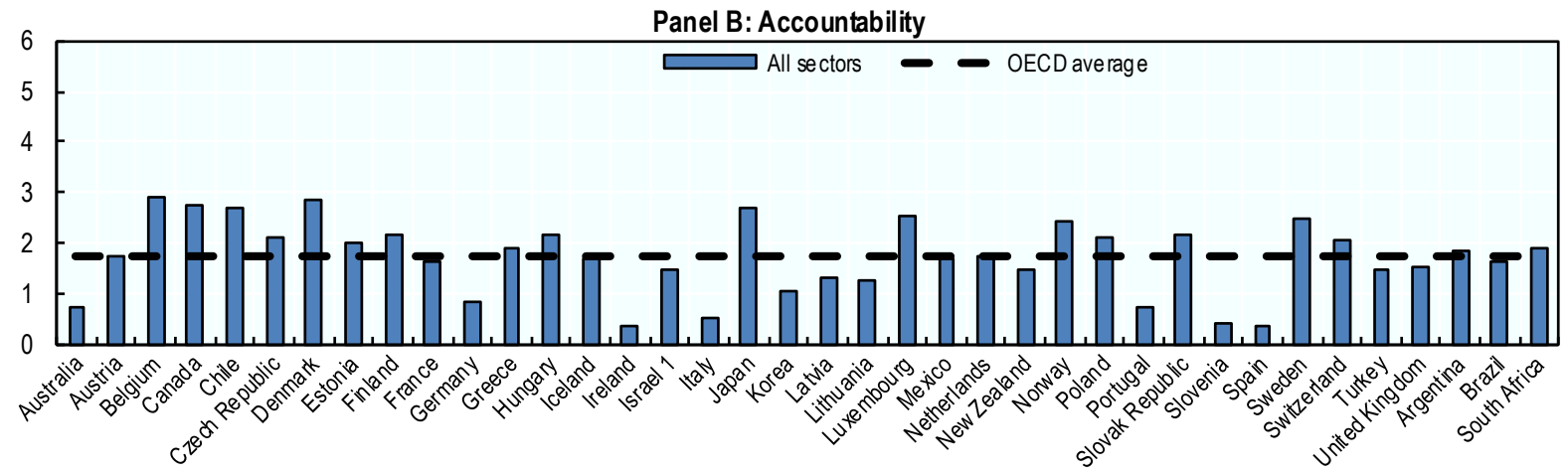

Panel C: Scope of action

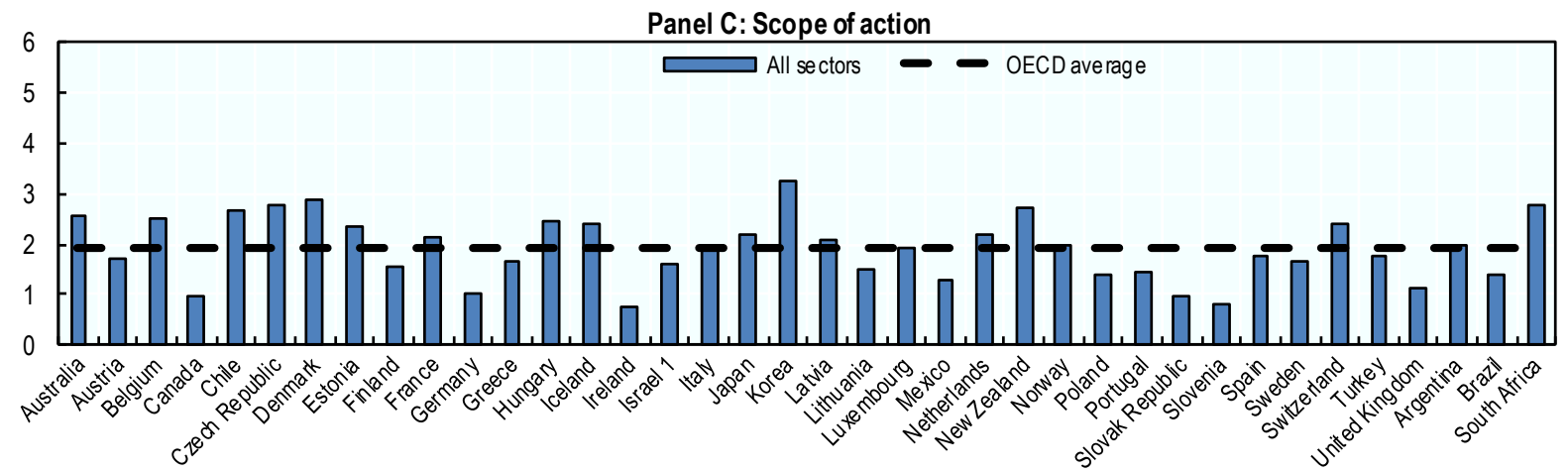

Notes:

The indicators vary from zero to six from the most to the least effective governance structure. The reported score is a simple average of the scores for each of the sector analysed.

1 The statistical data for Israel are supplied by and under the responsibility of the relevant Israeli authorities. The use of such data by the OECD is without prejudice to the status of the Golan Heights, East Jerusalem and Israeli settlements in the West Bank under the terms of international law.

Source: OECD 2018 Database on the Governance of Sector Regulators. 
Annex D. Aggregate scores, 2018

Table A. Average independence score by country and sector

\begin{tabular}{|c|c|c|c|c|c|}
\hline & Energy & E-communications & Rail transport & Air transport & Water \\
\hline Australia & 0.96 & 1.47 & 1.47 & 1.47 & 1.47 \\
\hline Austria & 1.47 & 1.27 & 0.74 & 2.53 & . \\
\hline Belgium & 1.10 & 1.02 & 1.52 & 1.18 & 2.69 \\
\hline Canada & 2.59 & 2.89 & 3.66 & 3.29 & \\
\hline Chile & 2.61 & 2.93 & 3.94 & 2.38 & 2.12 \\
\hline Czech Republic & 1.80 & 1.22 & 1.58 & 1.93 & 2.44 \\
\hline Denmark & 2.24 & 2.29 & 1.93 & 2.36 & 1.56 \\
\hline Estonia & 1.67 & & 1.67 & 1.67 & 1.67 \\
\hline Finland & 2.08 & 1.66 & 2.32 & & \\
\hline France & 0.99 & 1.07 & 1.39 & 1.72 & . \\
\hline Germany & 2.00 & 2.10 & 1.80 & . & . \\
\hline Greece & 1.47 & 1.41 & 1.62 & 2.98 & . \\
\hline Hungary & 1.41 & 0.86 & 2.16 & 2.21 & 1.30 \\
\hline Iceland & 2.10 & 2.27 & & . & \\
\hline Ireland & 1.77 & 1.44 & . & . & 1.52 \\
\hline Israel 1 & 1.42 & 1.80 & 1.99 & 1.38 & 1.49 \\
\hline Italy & 1.17 & 1.18 & 0.66 & 0.66 & 1.17 \\
\hline Japan & 2.41 & 3.25 & 3.17 & 2.83 & . \\
\hline Korea & 2.27 & 1.94 & & & 1.78 \\
\hline Latvia & 0.88 & 0.88 & 1.44 & 2.57 & 0.88 \\
\hline Lithuania & 1.46 & 1.54 & 1.82 & 2.42 & 1.46 \\
\hline Luxembourg & 1.77 & 1.77 & 1.88 & 1.88 & . \\
\hline Mexico & 1.13 & 0.66 & 2.79 & 2.72 & . \\
\hline Netherlands & 1.85 & 1.85 & 1.85 & 1.97 & 2.98 \\
\hline New Zealand & 1.81 & 1.87 & 2.52 & 3.18 & . \\
\hline Norway & 2.13 & 2.25 & 1.58 & 2.94 & . \\
\hline Poland & 1.52 & 1.85 & 1.58 & 2.57 & . \\
\hline Portugal & 0.79 & 1.02 & 1.02 & 1.02 & 0.92 \\
\hline Slovak Republic & 1.70 & 1.02 & 1.21 & . & 1.43 \\
\hline Slovenia & 1.38 & 1.27 & . & . & . \\
\hline Spain & 1.46 & 1.32 & 1.16 & 2.35 & . \\
\hline Sweden & 3.43 & 2.94 & 2.41 & 2.84 & . \\
\hline Switzerland & 2.70 & 2.43 & 2.16 & 3.41 & . \\
\hline Turkey & 1.37 & 1.82 & 2.97 & 1.94 & . \\
\hline United Kingdom & 1.27 & 1.56 & 1.66 & 1.51 & 2.29 \\
\hline Argentina & 1.44 & 3.22 & 2.02 & 3.03 & 2.37 \\
\hline Brazil & 0.94 & 0.56 & 1.14 & 1.46 & 1.98 \\
\hline South Africa & 1.35 & 1.32 & . & 3.93 & 3.11 \\
\hline
\end{tabular}

Note: The indicators vary from zero to six from the most to the least effective governance structure.

${ }^{1}$ The statistical data for Israel are supplied by and under the responsibility of the relevant Israeli authorities. The use of such data by the OECD is without prejudice to the status of the Golan Heights, East Jerusalem and Israeli settlements in the West Bank under the terms of international law.

${ }^{2}$ Responses were received for separate electricity and gas regulators in Argentina and Brazil. The table reports the average of the scores of the two energy regulators.

Source: OECD 2018 Database on the Governance of Sector Regulators. 
Table B: Average accountability score by country and sector

\begin{tabular}{|c|c|c|c|c|c|}
\hline & Energy & E-communications & Rail transport & Air transport & Water \\
\hline Australia & 1.09 & 0.55 & 0.70 & 0.64 & 0.55 \\
\hline Austria & 1.23 & 0.70 & 1.45 & 3.58 & \\
\hline Belgium & 1.64 & 0.00 & 4.26 & 4.26 & 4.29 \\
\hline Canada & 2.18 & 3.55 & 2.30 & 2.88 & \\
\hline Chile & 3.51 & 2.96 & 3.84 & 1.29 & 1.82 \\
\hline Czech Republic & 1.30 & 0.34 & 1.96 & 3.52 & 3.49 \\
\hline Denmark & 2.05 & 3.00 & 2.81 & 2.78 & 3.73 \\
\hline Estonia & 1.64 & . & 2.18 & 2.10 & 2.18 \\
\hline Finland & 1.82 & 1.36 & 3.27 & . & . \\
\hline France & 1.00 & 0.57 & 1.31 & 3.56 & . \\
\hline Germany & 1.25 & 0.70 & 0.55 & . & . \\
\hline Greece & 0.00 & 0.65 & 2.56 & 4.38 & . \\
\hline Hungary & 1.90 & 0.43 & 4.13 & 2.57 & 1.90 \\
\hline Iceland & 1.35 & 2.00 & . & . & . \\
\hline Ireland & 0.55 & 0.00 & . & . & 0.55 \\
\hline Israel 1 & 1.17 & 0.97 & 2.42 & 1.43 & 1.48 \\
\hline Italy & 0.82 & 0.00 & 0.45 & 0.45 & 0.90 \\
\hline Japan & 2.38 & 3.27 & 2.45 & 2.73 & . \\
\hline Korea & 2.18 & 0.35 & . & . & 0.55 \\
\hline Latvia & 0.55 & 0.55 & 2.04 & 2.86 & 0.55 \\
\hline Lithuania & 0.58 & 1.09 & 1.09 & 2.81 & 0.58 \\
\hline Luxembourg & 2.64 & 2.09 & 2.64 & 2.84 & . \\
\hline Mexico & 1.13 & 0.00 & 2.74 & 2.92 & . \\
\hline Netherlands & 1.71 & 1.90 & 1.64 & 1.79 & 1.64 \\
\hline New Zealand & 1.64 & 1.71 & 1.40 & 1.17 & . \\
\hline Norway & 2.18 & 2.45 & 2.25 & 2.88 & . \\
\hline Poland & 2.75 & 1.94 & 2.56 & 1.25 & . \\
\hline Portugal & 0.66 & 0.62 & 0.87 & 0.55 & 0.81 \\
\hline Slovak Republic & 2.01 & 1.35 & 4.64 & . & 0.74 \\
\hline Slovenia & 0.22 & 0.62 & . & . & . \\
\hline Spain & 0.00 & 0.00 & 0.23 & 1.17 & . \\
\hline Sweden & 2.53 & 3.00 & 2.31 & 2.13 & . \\
\hline Switzerland & 2.55 & 1.77 & 1.51 & 2.34 & . \\
\hline Turkey & 1.75 & 1.01 & 1.64 & 1.45 & . \\
\hline United Kingdom & 0.82 & 1.44 & 0.31 & 2.18 & 2.96 \\
\hline Argentina & 1.06 & 0.82 & 1.64 & 2.79 & 2.86 \\
\hline Brazil & 1.32 & 0.86 & 2.10 & 0.62 & 3.18 \\
\hline South Africa & 0.58 & 0.64 & . & 4.91 & 1.39 \\
\hline
\end{tabular}

Note: The indicators vary from zero to six from the most to the least effective governance structure.

${ }^{1}$ The statistical data for Israel are supplied by and under the responsibility of the relevant Israeli authorities. The use of such data by the OECD is without prejudice to the status of the Golan Heights, East Jerusalem and Israeli settlements in the West Bank under the terms of international law.

${ }^{2}$ Responses were received for separate electricity and gas regulators in Argentina and Brazil. The table reports the average of the scores of the two energy regulators.

Source: OECD 2018 Database on the Governance of Sector Regulators. 
Table C. Average scope of action score by country and sector

\begin{tabular}{|c|c|c|c|c|c|}
\hline & Energy & E-communications & Rail transport & Air transport & Water \\
\hline Australia & 0.46 & 2.77 & 2.31 & 4.15 & 3.23 \\
\hline Austria & 1.04 & 0.92 & 1.85 & 3.00 & \\
\hline Belgium & 3.46 & 0.92 & 1.85 & 2.42 & 3.92 \\
\hline Canada & 1.38 & 0.69 & 1.38 & 0.46 & \\
\hline Chile & 4.15 & 1.85 & 3.23 & 3.00 & 1.15 \\
\hline Czech Republic & 1.15 & 0.92 & 3.69 & 4.04 & 4.04 \\
\hline Denmark & 3.69 & 0.92 & 1.85 & 3.92 & 3.92 \\
\hline Estonia & 1.85 & . & 2.54 & 2.77 & 2.31 \\
\hline Finland & 2.77 & 0.00 & 1.85 & . & . \\
\hline France & 2.08 & 1.38 & 0.92 & 4.15 & . \\
\hline Germany & 0.46 & 0.46 & 2.08 & . & . \\
\hline Greece & 0.23 & 0.92 & 2.65 & 2.77 & . \\
\hline Hungary & 1.38 & 1.38 & 2.77 & 4.62 & 2.08 \\
\hline Iceland & 2.54 & 2.31 & . & . & . \\
\hline Ireland & 0.46 & 0.46 & . & . & 1.38 \\
\hline Israel 1 & 0.58 & 0.92 & 3.58 & 3.00 & 0.00 \\
\hline Italy & 1.50 & 1.04 & 2.31 & 4.15 & 0.81 \\
\hline Japan & 1.27 & 1.27 & 2.77 & 3.46 & . \\
\hline Korea & 3.23 & 3.00 & . & . & 3.58 \\
\hline Latvia & 0.92 & 0.92 & 2.31 & 4.38 & 1.85 \\
\hline Lithuania & 0.23 & 0.23 & 2.31 & 2.54 & 2.08 \\
\hline Luxembourg & 0.92 & 0.46 & 2.77 & 3.46 & . \\
\hline Mexico & 0.46 & 0.46 & 1.50 & 2.65 & . \\
\hline Netherlands & 0.69 & 1.15 & 3.23 & 2.31 & 3.46 \\
\hline New Zealand & 1.62 & 1.38 & 3.35 & 4.62 & . \\
\hline Norway & 1.62 & 0.92 & 2.08 & 3.23 & . \\
\hline Poland & 0.46 & 2.08 & 0.46 & 2.54 & . \\
\hline Portugal & 1.38 & 0.69 & 1.62 & 1.38 & 2.08 \\
\hline Slovak Republic & 0.46 & 0.46 & 2.08 & . & 0.92 \\
\hline Slovenia & 0.92 & 0.69 & . & . & . \\
\hline Spain & 2.31 & 0.92 & 1.62 & 2.31 & . \\
\hline Sweden & 1.15 & 0.00 & 2.77 & 2.77 & . \\
\hline Switzerland & 2.77 & 2.08 & 2.77 & 2.08 & . \\
\hline Turkey & 0.92 & 0.92 & 1.15 & 4.15 & . \\
\hline United Kingdom & 0.58 & 0.46 & 0.46 & 1.62 & 2.54 \\
\hline Argentina & 1.85 & 1.38 & 3.00 & 0.69 & 2.88 \\
\hline Brazil & 0.40 & 0.46 & 1.38 & 1.38 & 3.23 \\
\hline South Africa & 0.92 & 0.92 & . & 5.31 & 3.92 \\
\hline
\end{tabular}

${ }^{1}$ The statistical data for Israel are supplied by and under the responsibility of the relevant Israeli authorities. The use of such data by the OECD is without prejudice to the status of the Golan Heights, East Jerusalem and Israeli settlements in the West Bank under the terms of international law.

${ }^{2}$ Responses were received for separate electricity and gas regulators in Argentina and Brazil. The table reports the average of the scores of the two energy regulators.

Source: OECD 2018 Database on the Governance of Sector Regulators. 


\section{Annex E. Regulatory activities, by sector}

\section{Which activities can regulators engage in?}

By sector, percent of all answers

Panel A: Taking final decisions in disputes between market actors and regulated entities

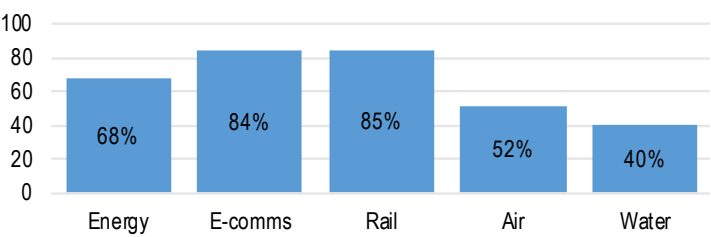

Panel C: Enforcing compliance with industry and consumer standards and regulatory commitments through legal punitive powers for non-compliance

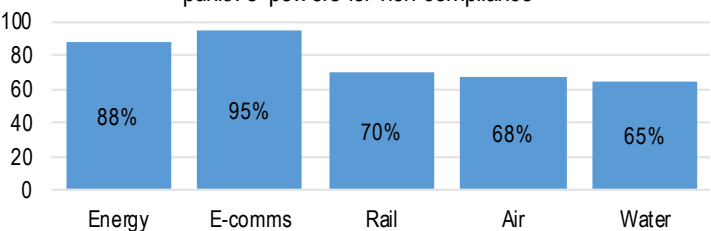

Panel E: Issuing consumer standards

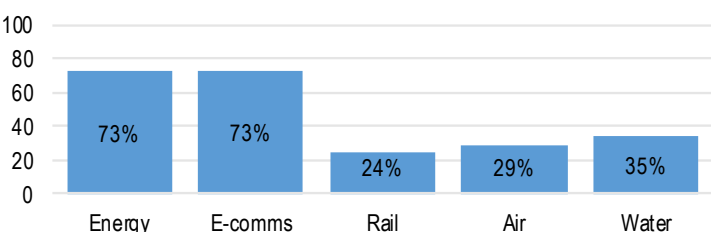

Panel G: Providing binding guidance, review and/or approve contract terms between regulated entities and/or market actors

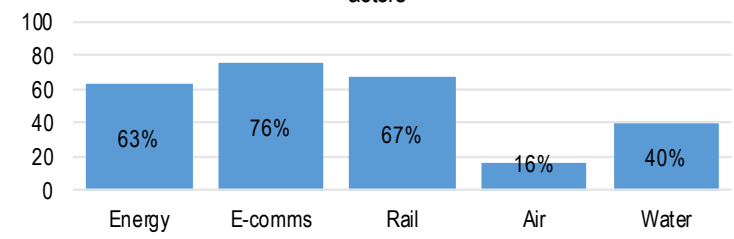

Panel I: Regulating monopoly prices

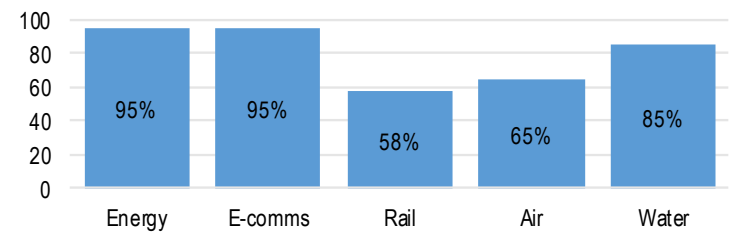

Panel B: Mediating to resolve disputes between market actors and regulated entities

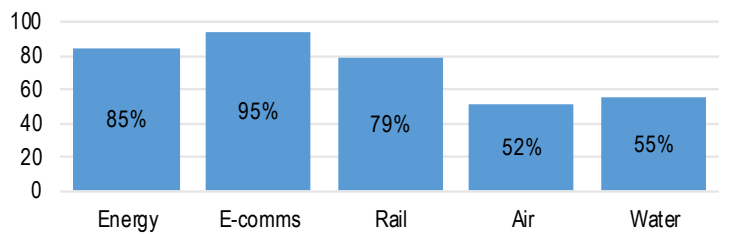

Panel D: Issuing guidelines and/or codes of conduct

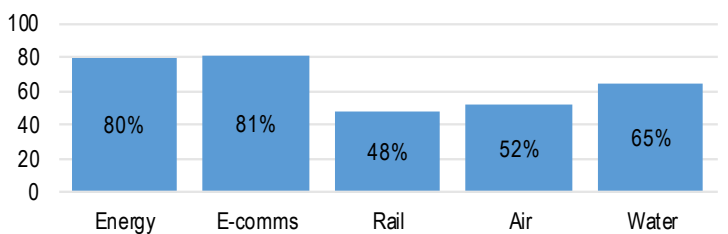

Panel F: Issuing industry standards

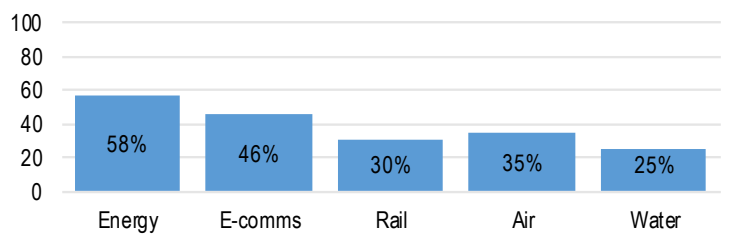

Panel $\mathrm{H}$ : Conducting research as an input for price setting

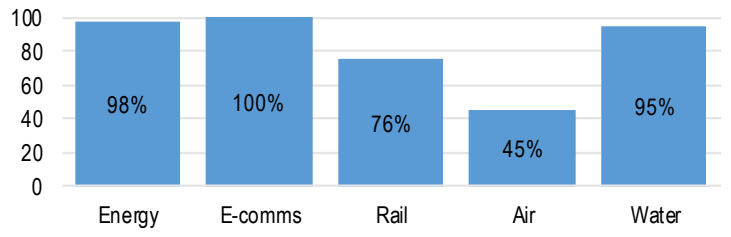

Panel J: Issuing and revoking licenses and/or denying or revoking authorisations

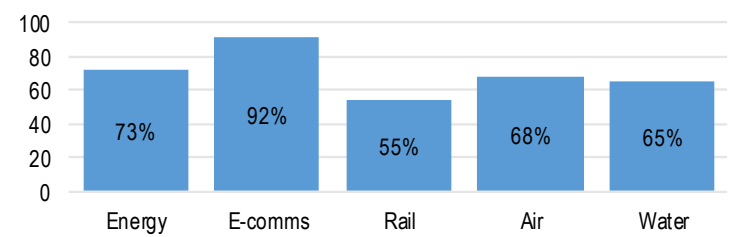

Source: OECD 2018 Database on the Governance of Sector Regulators. 


\section{Annex F. Why and how the 2018 and 2013 questionnaires differ}

79. The 2013 questionnaire included mostly questions capturing formal governance aspects. While formal aspects are necessary, they are not sufficient to guarantee the effective governance of regulators. The extent to which good governance principles are translated into practice is equally important to ensure that governance arrangements help regulators effectively perform their functions.

80. Following the development of the 2013 questionnaire, the OECD through its Network of Economic Regulators conducted work on independence and protecting regulators from undue influence, with a particular focus on the practical aspects or de facto elements of independence. This work has built on a survey of 48 regulators of 26 OECD and partner countries with open questions on the formal and practical aspects of independence $\left(\mathrm{OECD}, 2016_{[7]}\right)$. The survey led to the development of guidance on creating a culture of independence (OECD, 2017 $[23]$ ) . Furthermore, reviews of the organisational culture, structure and performance of regulatory agencies and case studies of regulators' practices have deepened the understanding of accountability, transparency and the overall effective functioning of regulatory agencies in practice $\left(\mathrm{OECD}, 2017_{[21]}\right.$; OECD, 2016 ${ }_{[17]}$; OECD, 2016[5]; OECD, 2015[24]).

81. The updates introduced in the 2018 questionnaire stem from this work and focus primarily on the independence component, with some related refinements in the accountability component. The updates seek to further identify what contributes to the emergence of an organisational culture of independence that supports trust and confidence that the decisions of the regulators are taken for the better functioning of sectors without undue influence.

82. The main changes address the following elements:

- Clarity of the role of the regulator vis-à-vis the executive (and other government bodies): updates focus on whether objective and functions are clearly defined and instances for overturning decisions are limited and defined. New questions include:

- Are the objectives and functions of the regulator defined?

- Are the instances where decisions of the regulator can be overturned by a body other than a court clearly defined?

- Recognition that regulators need to interact with government and other public and private stakeholders to effectively conduct their work: updates highlight the role of regulators in making recommendations or issuing opinions on draft legislation or policy documents, while keeping to their remit. In addition, for the accountability component, updates address the practice of reporting to government bodies, including parliament, as well as the use of data and evidence to motivate decisions. New questions include:

- Does the regulator make recommendations or issue opinions on draft legislation or policy documents proposed by the executive?

- Does the regulator need to motivate its regulatory decisions (e.g. with evidence and data)? 
- Does the regulator publish draft decisions and collect feedback from stakeholders?

- Does the regulator provide feedback on comments received by stakeholders?

- Is there a legislative requirement for the regulator to produce a report on its activities on a regular basis?

- Is there a legislative requirement for the regulator to answer requests from or attend hearings organized by parliamentary/congressional committees?

- Does the regulator present a report on its activities to one or more parliamentary/congressional committees?

- Integrity and protection of leadership from undue influence: updates capture the importance of a transparent appointment and, equally important, nomination (which tends to be less transparent) of board members or the head of the regulatory agency, the staggering and the length of board mandates to cut across the electoral cycle. New questions include:

- What is the process for selecting the agency head/board members?

- Which body has the legal authority to make the final appointment of the agency head/board members?

- Does the legislation define the skills required by the agency head/board members?

- If the regulator is led by a board, are appointments of board members staggered?

- What are the criteria for dismissing agency head/board members during their term of office?

- Are the criteria for dismissing agency head/board members during their term of office published?

- Independence of staff: a new question seeks to capture whether an open and fair competitive recruitment process is in place to create a culture of independence and integrity throughout the organisation:

- How is the majority of the staff recruited?

- Financial independence: updates replace the only question of the budget category (focusing on the sources of funding) of the 2013 questionnaire. They address: clarity on the sources of the budget and minimising opportunities for exercising pressure by adjusting regulatory fees or through an annual rather than multi-annual budget negotiation, budget execution autonomy balanced by appropriate accountability mechanisms on spending and needs. New questions include:

- Is the source of the financial budget of the regulator stated in the establishing legislation?

- What is the length of budget appropriations?

- If the regulator is financed in total or in part through fees paid by the regulated sector, who sets the level of the fees? 
- If the regulator is financed in total or in part through the national budget, who is responsible for proposing and discussing the regulator's budget?

- Does the regulator provide information to the legislature or the relevant budget authority on the costs and resources needed to fulfil its mandate prior to the next budget cycle?

- Which body is responsible for deciding the regulator's allocation of expenditures?

83. These changes limit the comparability of 2013 and 2018 results. 